\title{
Towards absolute plate motions constrained by lower-mantle slab remnants
}

\author{
Douwe G. van der Meer ${ }^{1,2 \star}$, Wim Spakman ${ }^{1 \star}$, Douwe J. J. van Hinsbergen ${ }^{1,3,4}$, Maisha L. Amaru ${ }^{1,5}$ \\ and Trond H. Torsvik ${ }^{3,4,6}$
}

\begin{abstract}
Since the first reconstruction of the supercontinent Pangaea, key advances in plate tectonic reconstructions have been made $^{1-6}$. Although the movement of tectonic plates since the start of the mid-Cretaceous period ( 100 million years (Myr) ago) is relatively well understood ${ }^{1,2}$, the longitudinal position of plates before this period is not constrained at all. Here, we use a global mantle tomography model $^{7}$ to estimate the longitude of past oceanic subduction zones. We identify 28 remnants of oceanic plates that were subducted into the lower mantle and link these to the mountain building zones from which they are likely to have originated. Assuming that these remnants sank vertically through the mantle, we reconstruct the longitude at which they were subducted. Our estimates for the location of the subduction zones are offset by up to $18^{\circ}$ compared with plate tectonic reconstructions for the corresponding period. We did not detect oceanic plate remnants from the Carboniferous period ( $200-360 \mathrm{Myr}$ ago), or before, suggesting that the tomographic visibility of subduction is limited to the past $\mathbf{3 0 0}$ Myr.
\end{abstract}

Since the first qualitative plate reconstruction of the supercontinent Pangaea was determined by fitting palaeoclimatic belts and modern continental margins, key advances in plate reconstructions have been made with the development and use of palaeomagnetic apparent polar wander paths, ocean floor magnetic anomalies and hotspot reference frames ${ }^{1,2}$, leading to global plate tectonic reconstructions $s^{3,5,6}$. Absolute plate motion models have often been based on assumed hotspot fixity and are well constrained only up to the Cretaceous period owing to the lack of any preserved older oceanic hotspot tracks ${ }^{1,2}$. These, and other models, offer no control on absolute palaeolongitude before the Cretaceous.

Seismic tomography studies of the mantle have allowed for increasingly detailed correlations between deep mantle structure, mostly focused on presumed remnants of subducted plates and plate tectonic evolution ${ }^{8-16}$. This, however, has not led to strong constraints on absolute plate motion. Recently, correlations between deep, presumably hot and dense mantle heterogeneities at the core-mantle boundary and large igneous provinces were obtained from a plate reconstruction ${ }^{3,4}$, leading to possible predictions of absolute palaeolongitude for the entire Phanerozoic eon ${ }^{17}$. This reconstruction model, however, assumes zero longitude motion for Africa before the Cretaceous.

Here, independently of any reconstruction model, we carry out a global interpretation of positive seismic anomalies in the lower mantle based on the assumptions that these reflect relatively cold remnants of subducted lithosphere ${ }^{8-16}$, and that slabs, once detached, sink more or less vertically in the mantle ${ }^{8-10,18}$ marking the location of their former subduction zones. Geological evidence for former subduction is constituted by orogens created in plate convergence zones, often comprising the remnants of a volcanic arc. Studies comparing the amount of Tethyan subducted material predicted by geological reconstructions with volumes of subducted lithosphere imaged in the mantle by seismic tomography ${ }^{11,12}$ suggest a first-order correlation between the onset and end of subduction and the onset and end of orogenesis, respectively. In line with this inference, we assume that to first order, the age of the base and top of a lower-mantle slab can be correlated in time with the onset and end, respectively, of the associated orogeny. Timing errors of the order of 10-25 Myr are inferred from the geological literature used for interpretation ${ }^{5,19-21}$ (Supplementary Information) and include uncertainties in upper-mantle subduction history.

Using this rationale, we interpret lower-mantle slab remnants from the tomographic model UU-P07 (ref. 7), the successor of BSE98 (ref. 22), and correlate these with their corresponding orogenies. Identification, depth of top and bottom, timing and images (Supplementary Figs S1-S28) of slab remnants are documented extensively in the Supplementary Information. The Farallon, Mongol-Okhotsk and Aegean Tethys slabs have already been studied extensively and correlated to geologic events and act here as anchor points for the global interpretation of the lower mantle. The still-subducting Aegean Tethys slab remnant was shown to reach a depth of $\sim 2,000 \pm 100 \mathrm{~km}$ (refs 11, 12, 22; Supplementary Fig. S1). The onset of subduction in the Aegean region is inferred to approximate $171 \pm 5 \mathrm{Myr}$, as represented by metamorphic soles below the oldest Aegean ophiolites ${ }^{23}$. The Mongol-Okhotsk slab remnant is located below northern Siberia from the base of the mantle up to mid-mantle (Supplementary Fig. S2) and subducted in the Middle Triassic/Middle Jurassic ${ }^{5,9,19}$. The Farallon slab remnant ${ }^{8}$ is located below eastern Laurentia from the deep lower mantle to the upper part of the lower mantle (Supplementary Fig. S3). The slab has been interpreted to represent eastward-subducted Farallon oceanic lithosphere, but estimates of the start of subduction of the slab vary from Late Cretaceous ${ }^{8}$ to Late Jurassic $^{13}$. However, the geological record proves that subduction at the western continental margin of Laurentia initiated earlier, in the Early Jurassic ${ }^{20,24}$. This is adopted here as the start of subduction and related to the deepest part of the Farallon slab remnant. In the upper mantle the Farallon slab disintegrates into smaller fragments, which have been associated with subduction during the

\footnotetext{
${ }^{1}$ Institute of Earth Sciences, Utrecht University, Budapestlaan 4, 3584 CD Utrecht, The Netherlands, ${ }^{2}$ Shell International Exploration and Production, Kesslerpark 2, 2288 GS Rijswijk, The Netherlands, ${ }^{3}$ Center for Geodynamics, Geological Survey of Norway (NGU), Leiv Eirikssons vei 39 , NO-7491 Trondheim, Norway, ${ }^{4}$ Physics of Geological Processes, University of Oslo, NO-0316 Oslo, Norway, ${ }^{5}$ Chevron Energy Technology Company, 250 St Georges Terrace, Perth, Western Australia 6000, Australia, ${ }^{6}$ School of Geosciences, University of the Witwatersrand, WITS 2050 Johannesburg, South Africa. *e-mail: douwe.vandermeer@shell.com; wims@geo.uu.nl.
} 
Table 1 | Slab data set.

\begin{tabular}{|c|c|c|c|c|c|c|c|c|c|c|c|c|c|c|c|}
\hline \multirow[b]{3}{*}{ Abbreviation } & \multirow[b]{3}{*}{ Slab name } & \multirow[b]{3}{*}{ Domain } & \multirow[b]{3}{*}{ Category } & \multicolumn{4}{|c|}{ Slab depth } & \multicolumn{4}{|c|}{ Slab age } & \multicolumn{4}{|c|}{ Slab midpoint } \\
\hline & & & & \multicolumn{2}{|c|}{ Base } & \multicolumn{2}{|c|}{ Top } & \multicolumn{2}{|c|}{ Base } & \multicolumn{2}{|c|}{ Top } & \multirow[b]{2}{*}{ Depth } & \multirow[b]{2}{*}{ Age } & \multirow[b]{2}{*}{ Long. $\left({ }^{\circ}\right)$} & \multirow[b]{2}{*}{ Lat. $\left({ }^{\circ}\right)$} \\
\hline & & & & Min. & Max. & Min. & Max. & Min. & Max. & Min. & Max. & & & & \\
\hline Aeg & Aegean Tethys & Tethyan & 1 & 2,100 & 1,900 & 0 & 0 & 176 & 166 & 0 & 0 & 1,000 & 86 & 26 & 42 \\
\hline Far & Farallon & Laurentian & 1 & 2,650 & 2,480 & 920 & 710 & 207 & 180 & 70 & 50 & 1,690 & 127 & -75 & 34 \\
\hline MO & Mongol-Okhotsk & Cathaysian & 1 & 2,900 & 2,815 & 1,900 & 1,700 & 240 & 230 & 180 & 155 & 2,329 & 201 & 76 & 67 \\
\hline $\mathrm{Ag}$ & Algeria & Tethyan & 2 & 2,300 & 2,100 & 1,500 & 1,325 & 180 & 155 & 155 & 131 & 1,806 & 155 & 8 & 21 \\
\hline $\mathrm{Al}$ & Aleutian & Laurentian & 1 & 810 & 710 & 0 & 0 & 84 & 52 & 0 & 0 & 380 & 34 & -165 & 57 \\
\hline At & Atlantis & Laurentian & 3 & 2,900 & 2,815 & 2,650 & 2,480 & 290 & 280 & 230 & 210 & 2,711 & 253 & -39 & 22 \\
\hline $\mathrm{Ba}$ & Balkan & Other & 3 & 2,900 & 2,815 & 2,650 & 2,480 & 280 & 260 & 220 & 200 & 2,711 & 240 & 17 & 47 \\
\hline $\mathrm{Bf}$ & Beaufort & Laurentian & 3 & 2,650 & 2,480 & 2,300 & 2,100 & 230 & 208 & 163 & 144 & 2,383 & 186 & -128 & 72 \\
\hline $\mathrm{Ca}$ & Caribbean & Laurentian & 1 & 810 & 710 & 0 & 0 & 72 & 59 & 0 & 0 & 380 & 33 & -63 & 13 \\
\hline $\mathrm{CC}$ & Central China & Cathaysian & 2 & 2,900 & 2,815 & 1,500 & 1,325 & 260 & 250 & 121 & 84 & 2,135 & 179 & 88 & 45 \\
\hline $\mathrm{Ch}$ & Chukchi & Laurentian & 3 & 1,900 & 1,700 & 1,325 & 1,175 & 163 & 144 & 120 & 100 & 1,525 & 132 & 170 & 77 \\
\hline EC & East China & Cathaysian & 2 & 2,900 & 2,815 & 1,900 & 1,700 & 253 & 243 & 163 & 153 & 2,329 & 203 & 128 & 43 \\
\hline $\mathrm{Eg}$ & Egypt & Tethyan & 3 & 1,500 & 1,325 & 920 & 810 & 121 & 84 & 84 & 70 & 1,139 & 90 & 26 & 19 \\
\hline GI & Georgia Islands & Other & 3 & 2,900 & 2,815 & 2,100 & 1,900 & 295 & 285 & 220 & 190 & 2,429 & 248 & -30 & -57 \\
\hline $\mathrm{Hi}$ & Himalayas & Tethyan & 2 & 1,175 & 1,040 & 500 & 440 & 84 & 79 & 43 & 20 & 789 & 57 & 78 & 26 \\
\hline Id & Idaho & Laurentian & 2 & 2,480 & 2,300 & 920 & 810 & 208 & 163 & 100 & 84 & 1,628 & 139 & -118 & 49 \\
\hline Kc & Kamchatka & Cathaysian & 1 & 920 & 810 & 0 & 0 & 100 & 84 & 0 & 0 & 433 & 46 & 155 & 55 \\
\hline Mc & Manchuria & Cathaysian & 1 & 920 & 810 & 0 & 0 & 110 & 50 & 0 & 0 & 433 & 40 & 135 & 46 \\
\hline Md & Maldives & Tethyan & 2 & 2,300 & 2,100 & 920 & 810 & 220 & 200 & 70 & 57 & 1,533 & 137 & 79 & 14 \\
\hline $\mathrm{Me}$ & Mesopotamia & Tethyan & 2 & 2,300 & 2,100 & 1,175 & 1,040 & 220 & 200 & 84 & 70 & 1,654 & 144 & 46 & 33 \\
\hline$M g$ & Mongolia & Cathaysian & 2 & 1,900 & 1,700 & 1,175 & 1,040 & 193 & 163 & 120 & 100 & 1,454 & 144 & 118 & 48 \\
\hline NP & North Pacific & Other & 3 & 1,700 & 1,500 & 810 & 710 & 140 & 110 & 110 & 80 & 1,180 & 110 & -143 & 56 \\
\hline Ro & Rockall & Other & 3 & 2,900 & 2,815 & 2,650 & 2,480 & 280 & 260 & 230 & 220 & 2,711 & 248 & -13 & 57 \\
\hline Sa & Sakhalin & Cathaysian & 2 & 1,175 & 1,040 & 810 & 710 & 100 & 84 & 84 & 52 & 934 & 80 & 149 & 53 \\
\hline So & Socorro & Laurentian & 2 & 2,100 & 1,900 & 1,020 & 920 & 208 & 163 & 100 & 84 & 1,485 & 139 & -108 & 17 \\
\hline TA & Trans Americas & Laurentian & 2 & 2,900 & 2,815 & 2,480 & 2,300 & 230 & 208 & 193 & 163 & 2,624 & 199 & -88 & -2 \\
\hline Ve & Venezuela & Laurentian & 2 & 1,500 & 1,325 & 810 & 710 & 118 & 110 & 72 & 59 & 1,086 & 90 & -67 & 2 \\
\hline Wc & Wichita & Laurentian & 2 & 2,815 & 2,650 & 2,100 & 1,900 & 230 & 208 & 193 & 163 & 2,366 & 199 & -95 & 35 \\
\hline
\end{tabular}

The slabs that are discussed in this letter are shown in bold. For a detailed overview, see the Supplementary Information and Supplementary Figs S1-S28.

Laramide orogeny (80-40 Myr) to present ${ }^{13,25}$. The total slab data set (Table 1, Supplementary Information), covers about half of the imaged positive wave-speed anomalies. For the remainder, notably in the deep mantle of the Indian and Pacific oceans, we could not date the slab remnants with the geological literature, or the tomographic model resolution was insufficient to warrant a useful quantitative interpretation.

Plotting the depths of the top and bottom of all slab remnants against the corresponding tectonic ages (Fig. 1) demonstrates an average slab sinking velocity in the lower mantle of $12 \pm 3 \mathrm{~mm} \mathrm{yr}^{-1}$. This result is obtained independent of mantle rheology and thus can serve as a new constraint in the determination of lower-mantle viscosity. The sinking rate is slower than inferred by mantle flow estimates using Mesozoic-Cenozoic subduction models ${ }^{18,26}$, which depend on assumed mantle rheology, but in agreement with other tomographic interpretations of $1-2 \mathrm{~cm} \mathrm{yr}^{-1}$ (refs $\left.10,12,14\right)$. Figure 1 shows that within the uncertainty estimates, the timing of palaeo-subduction can vary by $\pm 25 \mathrm{Myr}$ from the average, and slab remnants from palaeosubduction of any given age can be found $\pm 300 \mathrm{~km}$ from the corresponding average depth. Here we are primarily concerned with first-order inferences on palaeolongitude and lower-mantle sinking rates on a global scale.

We find that all slab remnants in the lowermost mantle correspond to subduction systems of Triassic-Permian age (Fig. 1). No geological argument is found for correlating the deepest positive wave-speed anomalies to Carboniferous, or older subduction systems. We infer that the tomographic visibility of subduction history may be restricted to the past $\sim 300 \mathrm{Myr}$ of Earth evolution.

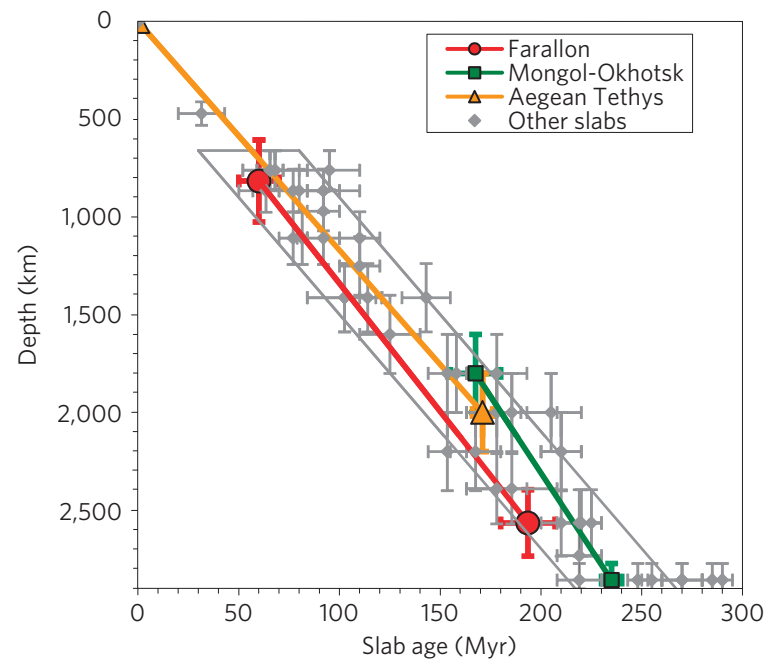

Figure 1 | Age-depth curve of interpreted slabs. The symbols indicate slab limits, with error bars in age-depth interpretation. The grey box represents average sinking rate $\left(\sim 12 \mathrm{~mm} \mathrm{yr}^{-1}\right)$. The colour-coded slabs are previously described marker slabs.

Using seismic-anomaly survival times, defined as a $50-100{ }^{\circ} \mathrm{C}$ temperature anomaly, from a recent $\operatorname{study}^{27}$, a slab maximum survival time of $300 \mathrm{Myr}$ for slabs may indicate an increase in lower-mantle viscosity by a factor 100-300 relative to the upper 

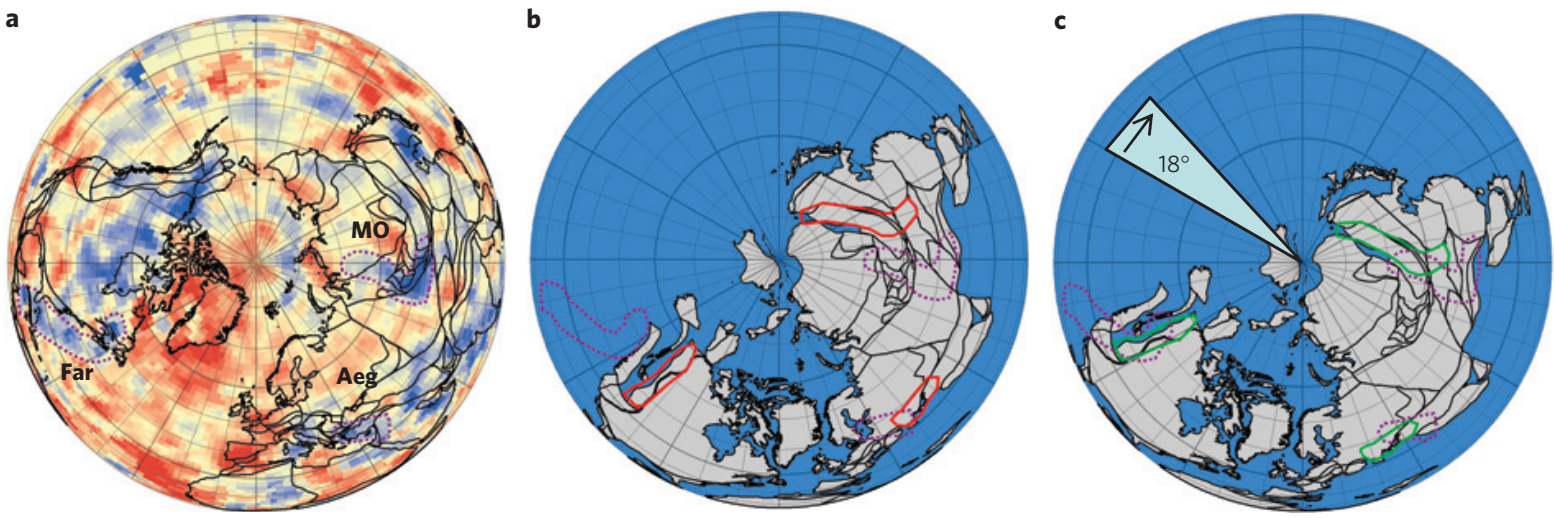

Figure 2 | Spatial longitude correction. North Pole orthographic projections. a, Tomographic depth slice ${ }^{7}$ at 1,900 km, colour scale red ( $-0.4 \%$ ) to blue $(+0.4 \%)$ with present-day continents. Interpreted slabs are outlined in purple: Far, Farallon; Aeg, Aegean Tethys; MO, Mongol-Okhotsk. b, Unmodified reconstruction at 160 Myr. Offsets exist between the three slabs (purple) and their corresponding subduction complexes/sutures (red outlines). c, To obtain an improved fit between subduction complexes/sutures (green) and slab locations (purple), the plate tectonic reconstruction was shifted $18^{\circ}$ westward.



Figure $\mathbf{3}$ | Longitude correction with time. The blue triangles note a good global fit between slabs and continental plate margins. The orange squares note fits where some slabs are offset to the margins. The blue line represents the applied longitude correction to the plate tectonic reconstruction, based on the moving average of good global fits. The red dashed lines and arrows indicate the uncertainty, varying with latitude, to a lateral uncertainty of $500 \mathrm{~km}$ in the surface location of a palaeo-subduction zone.

mantle. The numerical mantle flow model ${ }^{27}$ however, is based on mid-mantle observation and subducting continuous slabs, whereas our survival time estimate pertains to the lowermost mantle and detached slab remnants.

Tomographic invisibility can be caused by thermal assimilation, and/or mantle mixing, for example, by recycling in mantle plumes as indicated by geochemical signatures ${ }^{28}$. Recycling times of subducted oceanic lithosphere can be as short as a few hundred million years as indicated in the isotope geochemistry of some mantle plumes ${ }^{29,30}$. These short recycling times suggest that the deepest slab remnants may be the elusive source of recycled slab material observed in plumes, mixed with components of up to Archaean age ${ }^{29}$. Our observation of tomographic invisibility provides new input for future thermochemical dynamic modelling studies of slab survival in the deepest mantle.
To illustrate the implications for palaeo-longitude shifts of continents back to the Permo-Triassic, we use a plate tectonic reconstruction $^{3}$, recently corrected for true polar wander ${ }^{4}$ between 100 and $300 \mathrm{Myr}$. From 12 depth slices in the lower mantle, corresponding to subduction during the time frame 40-260 Myr (Supplementary Figs S29-S40), we determine the shift of palaeo-longitudes of continental blocks from the inferred palaeo-subduction zone positions of the 28 slab remnants. As an example, we show how the three anchor slabs ${ }^{8,9,11}$ constrain the plate tectonic reconstruction ${ }^{3,4}$ (Fig. 2). A depth slice at 1,900 km in the tomographic model $^{7}$ corresponds to $\sim 160 \mathrm{Myr}$ of the plate tectonic reconstruction (Fig. 1). The unmodified reconstruction shows the Mongol-Okhotsk slab ${ }^{9}$ to be located below central Asia, the Aegean Tethys slab ${ }^{11}$ below central Europe and the Farallon slab ${ }^{8}$ to be completely below the eastern Panthalassa Ocean (Fig. 2). All slabs are positioned too far west with respect to the subduction location inferred by the geological record ${ }^{8,9,11}$. A $16^{\circ}-18^{\circ}$ westward shift of the reconstruction provides the best fit, between slab remnants at depth and the surface location of subduction. Clearly, some offsets remain between our palaeosubduction positions inferred from tomography and the modified plate tectonic construction (Fig. 2c). These discrepancies approach the uncertainties in the inferred surface location of palaeo-subduction with an estimated lateral spatial r.m.s. uncertainty of $\sim 250-500 \mathrm{~km}$ resulting from the effects of unknown slab dip $(\sim 300-700 \mathrm{~km})$, lower-mantle thickening of slabs $(\sim 200-400 \mathrm{~km})$ and tomographic imaging error ( $200-400 \mathrm{~km})$ of the interpreted medium to well-imaged slab remnants. Other uncertainties are due to complexities in the slab subduction history, for example, the northern Farallon slab is related to subduction at the continental margin, but its southern extent may have been caused by simultaneous intraoceanic subduction ${ }^{20}$.

An important overall observation is that, at each time slice considered, the relative position of continental fragments in the plate reconstruction ${ }^{3,4}$ proves largely consistent with our inferred relative positions of palaeosubduction zones (Fig. 2, Supplementary Figs S29-S40). This gives confidence in the plate reconstruction ${ }^{3,4}$ used and in our inferred palaeo-subduction zone configurations. This also allows us to concentrate on longitude shifts per time slice of the entire assembly of continental fragments. These are summarized in Fig. 3, whereas Fig. 4 serves to illustrate our interpretation process. In Fig. 4 and Supplementary Figs S29-S40, we also speculate on the palaeo-position of intra-oceanic blocks, spreading ridges and transform zones, but this is not essential for our analysis of absolute palaeolongitude. 

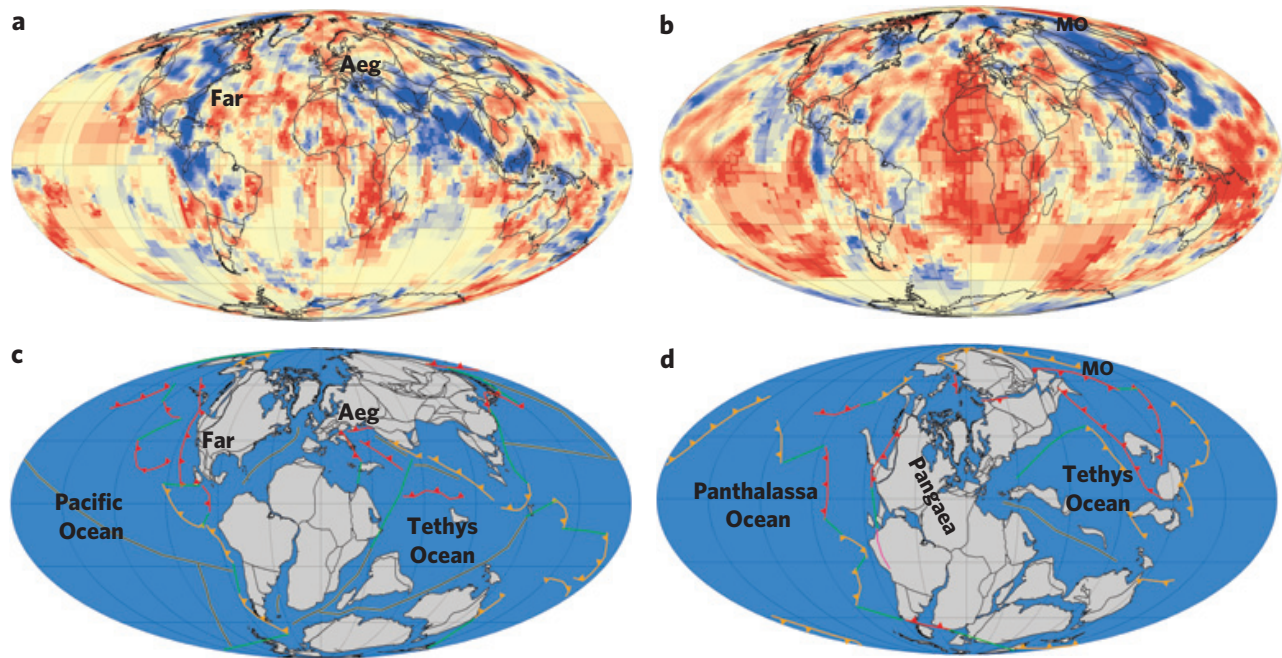

Figure 4 | Longitude-corrected plate tectonic reconstructions. The colour scale is given in Fig. 2 and slab name abbreviations are given in Table 1. a-d, A good fit is obtained between the tomographic depth slices ${ }^{7}$ at $1,325 \mathrm{~km}(\mathbf{a})$ and 2,650 km (b) depth and the modified plate tectonic reconstructions $\mathrm{s}^{3,4}$ at $120 \mathrm{Myr}\left(17^{\circ}\right.$ corrected) (c) and $240 \mathrm{Myr}\left(10^{\circ}\right.$ corrected) (d). Tectonic interpretation: lines with triangles, subduction zone of the slab data set (red) and other slabs with only a qualitative interpretation (orange); green line, transform zone; yellow double line, spreading ridge. See Supplementary Figs S29-S40 for larger maps.

On the basis of slab remnants between $45^{\circ} \mathrm{N}$ and $45^{\circ} \mathrm{S}$, we find that palaeolongitudes gradually depart between 40 and $120 \mathrm{Myr}$, amounting to a westward longitude shift of $18^{\circ}-20^{\circ}$ between 120 and $180 \mathrm{Myr}$, after which a gradual decrease occurs to $8^{\circ}$ at $260 \mathrm{Myr}$ (Fig. 3). Owing to uncertainties, this departure is significant from $\sim 80$ to $\sim 260 \mathrm{Myr}$ and provides new constraints on the palaeolongitude of the entire continental-plate configuration through time. Figure 4 shows that the continents on the Northern Hemisphere are constrained by slabs on either side of the palaeo-Pacific Ocean (for example, Farallon $\mathrm{slab}^{8}$ ) and by Tethys Ocean slabs (for example, Aegean Tethys slab ${ }^{11}$ ). The longitude correction decreases to $\sim 10^{\circ}$ in the Late Permian-Triassic (200-260 Myr). Bordered by slabs at its western and eastern side (for example, Mongol-Okhotsk slab ${ }^{9}$ ), Pangaea is also constrained in absolute longitude (Fig. 4).

Our global atlas of subduction remnants agrees through geological time with the relative positions of continental plates and agrees within $18^{\circ}-20^{\circ}$ with the palaeolongitude of the entire continental assembly as given by the plate reconstruction ${ }^{3,4}$ used for comparison. The latter reconstruction also proposes absolute palaeo-longitudes of continental plates ${ }^{17}$. Given the uncertainties underlying both approaches, we have obtained a rather close match between independently proposed palaeolongitudes through time. The required longitude corrections do not significantly affect the correlation between mantle heterogeneities at the core-mantle boundary and large igneous provinces ${ }^{17}$.

The longitude correction pattern of Fig. 3 may reflect Pangaea (Africa) wandering in longitude, but does require further investigation, eventually leading to an integration of both approaches and a further quantification of plate reconstructions. Here, we have focused on new inferences on absolute plate motion, lower-mantle sinking rates and the tomographic visibility of slab remnants, potentially useful as constraints on mantle rheology and on geodynamic modelling of crust-mantle evolution.

\section{Methods}

We selected only imaged anomalies in the UU-P07 tomographic model ${ }^{7}$, with peak velocity amplitudes above $+0.4 \%$, and overall amplitudes above $+0.2 \%$ to delineate slab boundaries ${ }^{12}$. Subduction zones associated with large oceanic basins are expected to be of considerable lateral extent; therefore, the interpretation is further restricted to laterally elongated deep-mantle anomalies, leading to the data set of 28 slab remnants (Table 1). The Supplementary Information provides our global atlas of slab remnant interpretations, which may prove useful for future tomographic and plate tectonic studies. The radial error in the depth interpretation varies from $\pm 100 \mathrm{~km}$ in the shallow lower mantle to $\pm 200 \mathrm{~km}$ in the deeper lower mantle.

The set of 28 slabs is subdivided into three confidence categories. Category I slabs have previously been interpreted in tomographic studies and correlated to their respective orogen $s^{8-13}$. Age uncertainties are derived from geological literature. Vertical spatial uncertainties are conservative (upper) estimates of image blurring effects.

Slabs in category II are found in the vicinity of a category I slab, providing a palaeogeographic link to the latter, assuming they have been created and shaped in the same boundary region between two converging plates. Candidates for corresponding orogens are identified from palaeo-geographic reconstructions ${ }^{5,19-21}$, which are primarily determined from the synthesis of geological and palaeo-magnetic data. For slabs of category III, there is no apparent relation with other slabs, or the interpretation of subduction remnants has led to relatively larger uncertainties in subduction timing and depth as compared with the first two categories.

The initial identification of category II and III slabs from palaeo-geographic reconstructions is tied in with the interpretations of category I slabs. The subsequent estimates for top and bottom depth from the tomographic model and the more precise timing of start and end of subduction from the geological literature are independent of this initial identification process.

To test the data-set robustness, the time-depth data set is split in various ways: separately considering the top and base of slab remnants (Supplementary Fig. S41), per slab remnant confidence category (Supplementary Fig. S42) and per region (Supplementary Fig. S43).

The longitude correction was estimated by correlating the plate tectonic reconstruction in $20 \mathrm{Myr}$ steps with the closest available depth slice (tomographic layer), based on the average time-depth conversion as indicated by the slab data set. Global longitude shifts were applied in $2^{\circ}$ steps and the fit quality was assessed between the active palaeo-margins at surface and slab remnants at depth. Latitudes of continental fragments were not changed, except for the North China block in the Permo-Triassic. Mesozoic Europe has been simplified by excluding small continental fragments at its southern margin. Where flat-slab orogenies occurred, the intra-plate edge of crustal deformation was taken to match the dispersed slabs remnants. Locations of spreading ridges and transform zones have also been added, but are based on speculation.

Received 10 June 2009; accepted 2 November 2009; published online 6 December 2009

\section{References}

1. Müller, R., Royden, J. \& Lawver, L. Revised plate motions relative to the hotspots from combined Atlantic and Indian Ocean hotspot tracks. Geology 21, 275-278 (1993).

2. Norton, I. The History of Global Plate Motions 339-357 (Geophysical Monograph Vol. 121, 1996).

3. Torsvik, T., Müller, R., van der Voo, R., Steinberger, B. \& Gaina, C. Global plate motion frames: Toward a unified model. Rev. Geophys. 46, 1-44 (2008). 
4. Steinberger, B. \& Torsvik, T. Absolute plate motions and true polar wander in the absence of hotspot tracks. Nature 452, 620-624 (2008).

5. Stampfli, G. \& Borel, G. D. The TRANSMED Transects in Space and Time: Constraints on the Paleotectonic Evolution of the Mediterranean Domain: The TRANSMED Atlas Ch. 3 (Springer, 2004).

6. Scotese, C. Atlas of Earth History (PALEOMAP Project, 2001).

7. Amaru, M. Global Travel Time Tomography With 3-D Reference Models, Geol. Traiectina. PhD thesis, Utrecht Univ. 1-174 (2007).

8. Grand, S., van der Hilst, R. \& Widiyantoro, S. Global seismic tomography: A snapshot of convection in the earth. GSA Today 7, 1-7 (1997).

9. van der Voo, R., Spakman, W. \& Bijwaard, H. Mesozoic subducted slabs under Siberia. Nature 397, 246-249 (1999).

10. van der Voo, R., Spakman, W. \& Bijwaard, H. Tethyan slabs under India. Earth Planet. Sci. Lett. 171, 7-20 (1999).

11. van Hinsbergen, D., Hafkenscheid, E., Spakman, W., Meulenkamp, J. \& Wortel, M. Nappe stacking resulting from subduction of oceanic and continental lithosphere below Greece. Geology 33, 325-328 (2005).

12. Hafkenscheid, E., Wortel, M. \& Spakman, W. Subduction history of the Tethyan region derived from seismic tomography and tectonic reconstructions. J. Geophys. Res. 111, B08401 (2006).

13. Sigloch, K., McQuarrie, N. \& Nolet, G. Two-stage subduction history under North America inferred from multiple-frequency tomography. Nature Geosci. 1, 458-462 (2008).

14. Schellart, W., Kennett, B., Spakman, W. \& Amaru, M. Plate reconstructions and tomography reveal a fossil lower mantle slab below the Tasman Sea. Earth Planet. Sci. Lett. 278, 143-151 (2009).

15. De Jonge, M., Wortel, M. \& Spakman, W. From tectonic reconstruction to upper mantle model: An application to the Alpine-Mediterranean region. Tectonophysics 223, 53-65 (1993).

16. Hall, R. \& Spakman, W. Subducted slabs beneath the eastern Indonesia-Tonga region: Insights from tomography. Earth Planet. Sci. Lett. 201, 321-336 (2002).

17. Torsvik, T., Steinberger, B., Cocks, L. \& Burke, K. Longitude: Linking Earth's ancient surface to its deep interior. Earth Planet. Sci. Lett. 276, 273-282 (2008).

18. Steinberger, B. Slabs in the lower mantle-results of dynamic modelling compared with tomographic images and the geoid. Phys. Earth Planet. Inter. 118, 241-257 (2000).

19. Golonka, J. et al. Paleogeographic reconstructions and basins development of the Arctic. Mar. Petrol. Geol. 20, 211-248 (2003).

20. Nokleberg, W. et al. Phanerozoic tectonic evolution of the circum-north Pacific USGS Professional Paper 1626 (2000).

21. Cawood, P. \& Buchan, C. Linking accretionary orogenesis with supercontinent assembly. Earth Sci. Rev. 82, 217-256 (2007).

22. Bijwaard, H., Spakman, W. \& Engdahl, E. Closing the gap between regional and global travel time tomography. J. Geophys. Res. 103, 30055-30078 (1998).
23. Liati, A., Gebauer, D. \& Fannink, C. The age of ophiolitic rocks of the Hellenides (Vourinos, Pindos, Crete): First U-Pb ion microprobe (SHRIMP) zircon ages. Chem. Geol. 207, 171-188 (2004).

24. DeCelles, P., Ducea, M., Kapp, P. \& Zandt, G. Cyclicity in Cordilleran orogenic systems. Nature Geosci. 2, 251-257 (2009).

25. van der Lee, S. \& Nolet, G. Seismic image of the subducted trailing fragments of the Farallon plate. Nature 386, 266-269 (1997).

26. Ricard, Y., Richards, M., Lithgow-Bertollini, C. \& Le Stunff, Y. A geodynamic model of mantle density heterogeneity. J. Geophys. Res. 98, 21895-21909 (1993).

27. Jarvis, G. \& Lowman, J. Survival times of subducted slab remnants in numerical models of mantle flow. Earth Planet. Sci. Lett. 260, 23-36 (2007).

28. Chauvel, C., Lewin, E., Carpentier, M., Arndt, N. \& Marini, J. Role of recycled oceanic basalt and sediment in generating the Hf-Nd mantle array. Nature Geosci. 1, 64-70 (2008).

29. Schaefer, B., Turner, S., Parkinson, I., Rogers, N. \& Hawkesworth, C. Evidence for recycled Archaean oceanic mantle lithosphere in the Azores plume. Nature 420, 304-307 (2002).

30. Hauff, G., Hoernle, K., Tilton, G., Graham, D. \& Kerr, A. Large volume recycling of oceanic lithosphere over short timescales: Geochemical constraints from the Caribbean Large Igneous Province. Earth Planet. Sci. Lett. 174, 247-263 (2000).

\section{Acknowledgements}

We would like to thank the various people of Shell in Rijswijk, the Netherlands, for the valuable discussions on regional geology, A. Crince for technical support and R. Hall and P. Cawood for fruitful comments. Part of this work was conducted under programmes of the Vening Meinesz School of Geodynamics (VMSG, Utrecht University) and the Netherlands Research Centre of Integrated Solid Earth Sciences (ISES). D.J.J.v.H acknowledges an NWO-VENI grant. This paper contributes to the ESF EUROCORES programme TOPO-EUROPE.

\section{Author contributions}

D.G.v.d.M. carried out the global tomographic slab identification, longitude correction and plate tectonic reconstruction modifications, partly during his sabbatical at the NGU. W.S. co-developed the tomographic model and the ideas underlying the research presented here. D.J.J.v.H. provided integration between surface geology, orogenesis and subduction. M.L.A. developed the tomographic model as part of her $\mathrm{PhD}$ work at Utrecht University. T.H.T. provided the plate tectonic reconstructions. The first three authors shared equally in writing the article.

\section{Additional information}

The authors declare no competing financial interests. Supplementary information accompanies this paper on www.nature.com/naturegeoscience. Reprints and permissions information is available online at http://npg.nature.com/reprintsandpermissions. Correspondence and requests for materials should be addressed to D.G.v.d.M. or W.S 


\section{Supplementary Information}

belonging to the article:

Absolute plate motions since the Permian inferred from lower mantle slab remnants 


\section{Aeg - Aegean Tethys}

a)

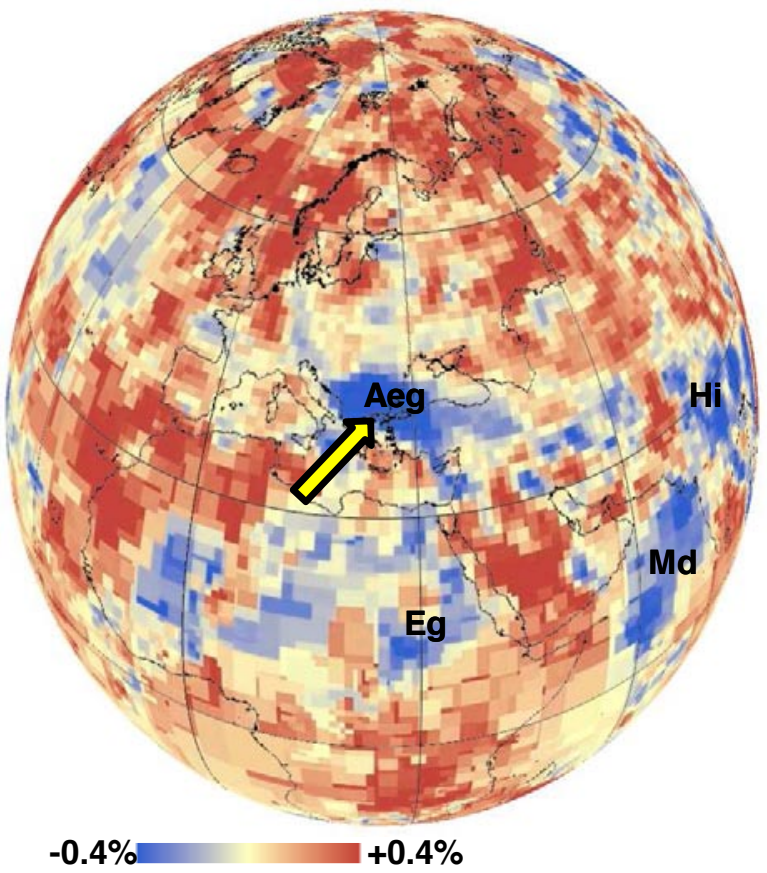

b)
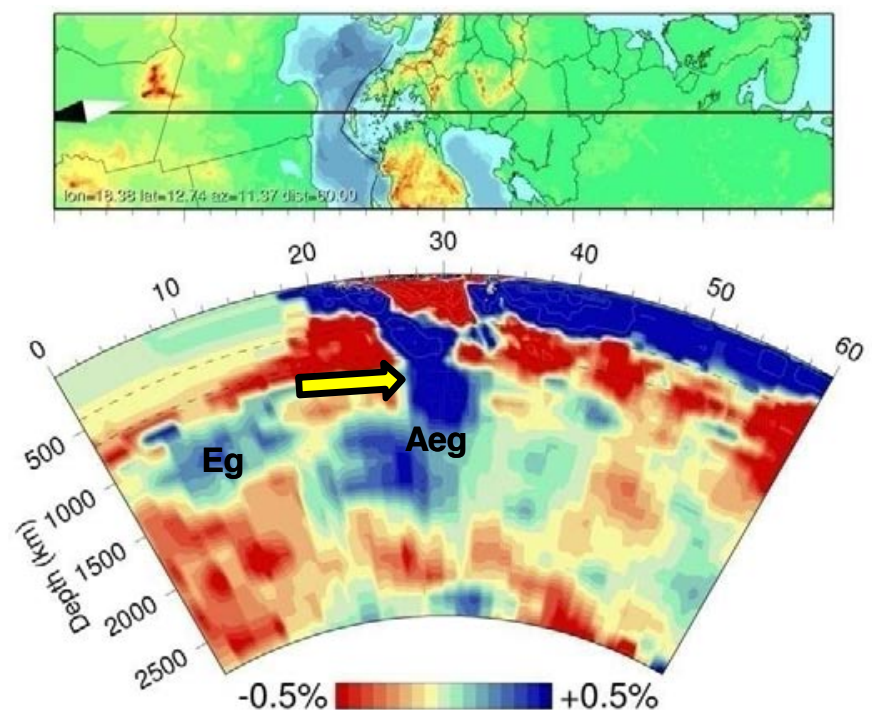

Supplementary Figure 1 Cross-sections of the tomographic model a) horizontal at $920 \mathrm{~km}$ projected on Earth's surface $b$ ) vertical. The slab is indicated by arrows

The Aegean Tethys slab is located below south east Europe from the deep lower mantle up to the surface at the Hellenic subduction zone. Van der Voo et al. (1999b) identified this slab as the II anomaly, and interpreted it to represent northward subducted NeoTethyan lithosphere. Van Hinsbergen et al. (2005) subdivided the slab into a deep anomaly between 2000 and $1500 \mathrm{~km}$ associated with intra-oceanic subduction in the Vardar Ocean, and an anomaly from $1500 \mathrm{~km}$ to the surface, both associated with continuous northward subduction and accretion of the Aegean mountain belt. The onset of subduction started with the inversion of the Vardar spreading ridge indicated by a metamorphic sole of the Vardar ophiolites (including the Pindos, Vourinos and Othris ophiolites in Greece), dated at 168.5 \pm 2.4 to 172.9 $\pm 3.1 \mathrm{Ma}$ by Liati et al. (2004), which we adopt as the age of the base of the deepest anomaly. Stampfli \& Borel (2004) have a similar Mid-Jurassic start of subduction in this region, but suggested an initially opposite direction of subduction of the Maliac oceanic plate. For the age of the bottom of the slab, this interpretation yields the same result.

- $\quad$ Derived midpoint (lon, lat, depth): 26421000

- Age slab (max-min): $171+/-5$ Ma to present

- Category: I, Region; Tethyan 


\section{MO - Mongol-Okhotsk}

a)

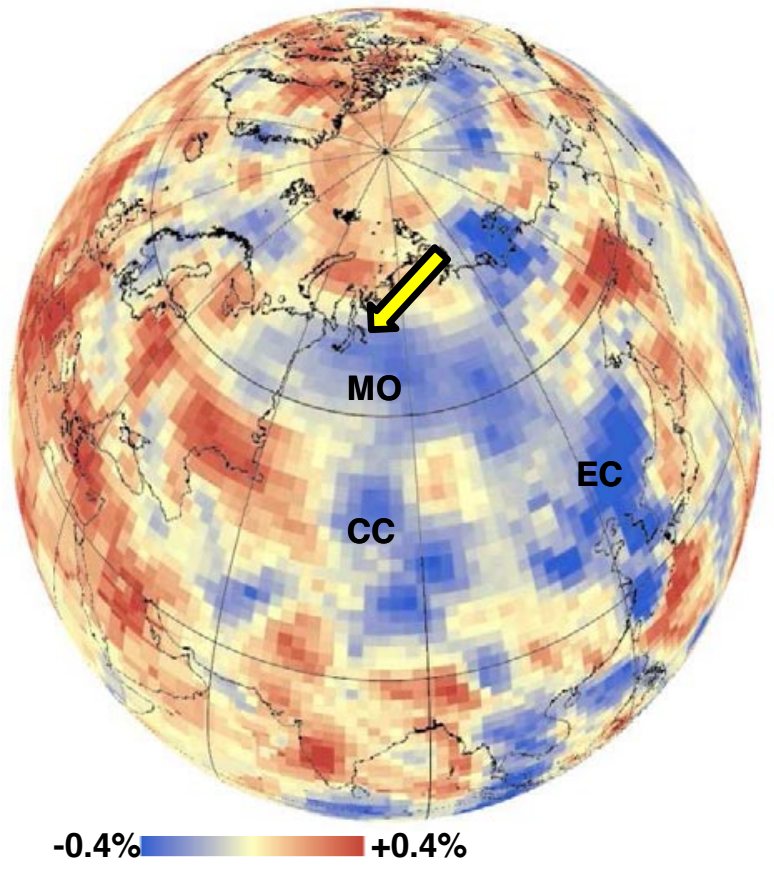

b)
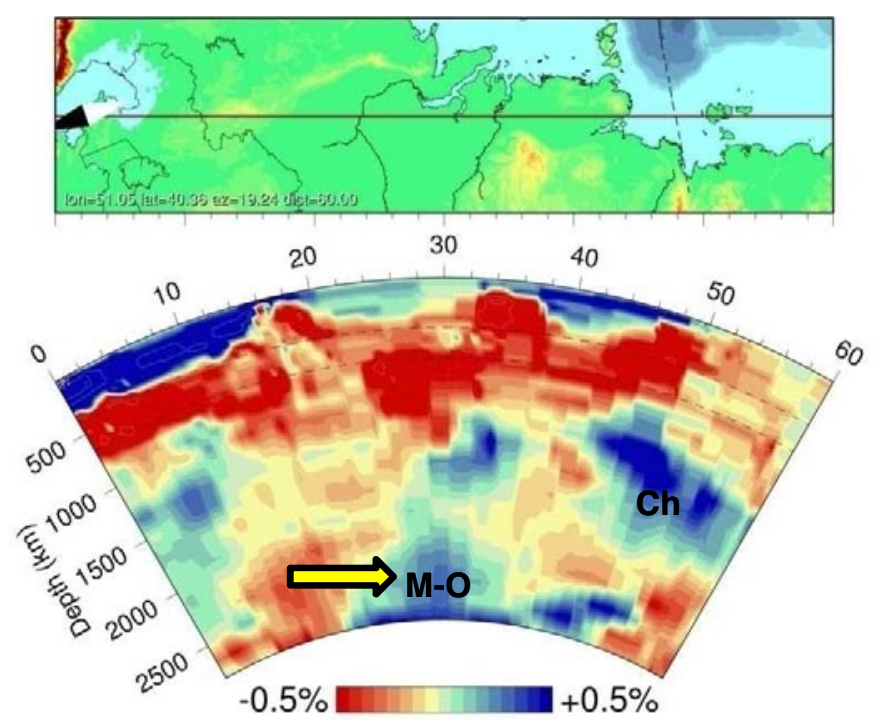

Supplementary Figure 2 Cross-sections of the tomographic model a) horizontal at $2480 \mathrm{~km}$ projected on Earth's surface $b$ ) vertical. The slab is indicated by arrows

- The Mongol-Okhotsk slab is located below northern Siberia from the base of the mantle up to mid-mantle. The slab has been interpreted to represent subducted Mongol-Okhotsk oceanic lithosphere ending in the late Jurassic (van der Voo et al. (1999a)). The base of the slab merges with the graveyard of slabs under Asia at the base of the mantle (van der Voo et al.1999a). By adapting the global plate tectonic reconstructions (Torsvik et al. (2008), Stampfli and Borel (2004)), we have reinterpreted the southern part of the Z-shaped Mongol-Okhotsk slab (van der Voo et al.1999a) to be the remnant of eastward subducted PaleoTethys lithosphere (redefined into CC slab), whereas the northern part represents the "true" remnant of Mongol-Okhotsk subduction. At the southern margin of Siberia subduction initiated in the middle Triassic (Stampfli and Borel (2004), Golonka (2003)) and ended in the middle Jurassic when the closure of the Mongol-Okhotsk Ocean was completed by collision with the North China block (Stampfli and Borel (2004), van der Voo et al. (1999a), Golonka (2003)).

- $\quad$ Derived midpoint (lon, lat, depth): 76672329

- $\quad$ Age slab (max-min): $235+/-5$ to $168+/-13 \mathrm{Ma}$

- Category: I, Region; Cathaysian 


\section{Far - Farallon}

a)

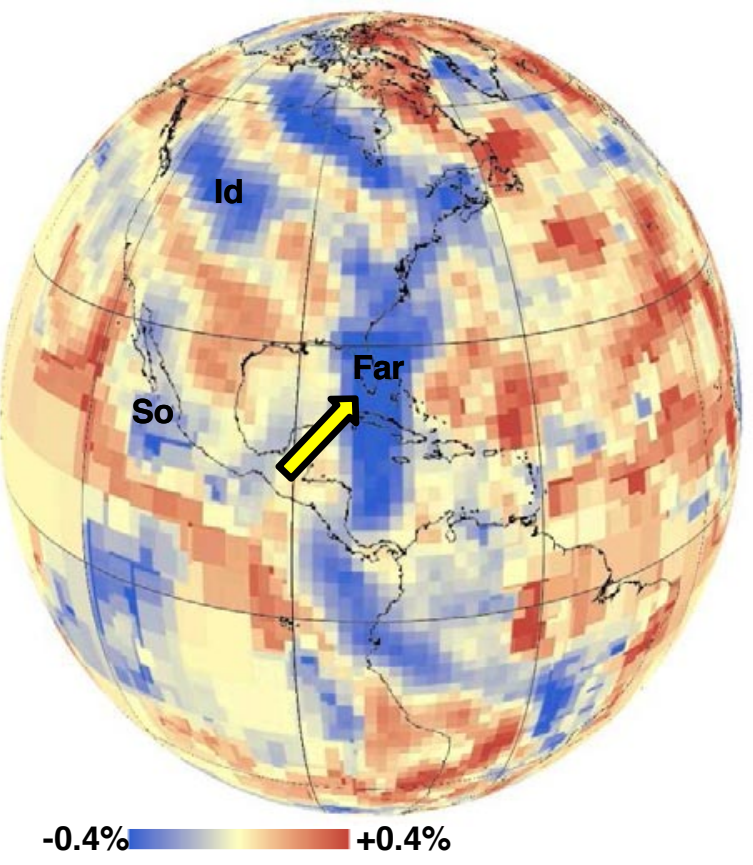

b)

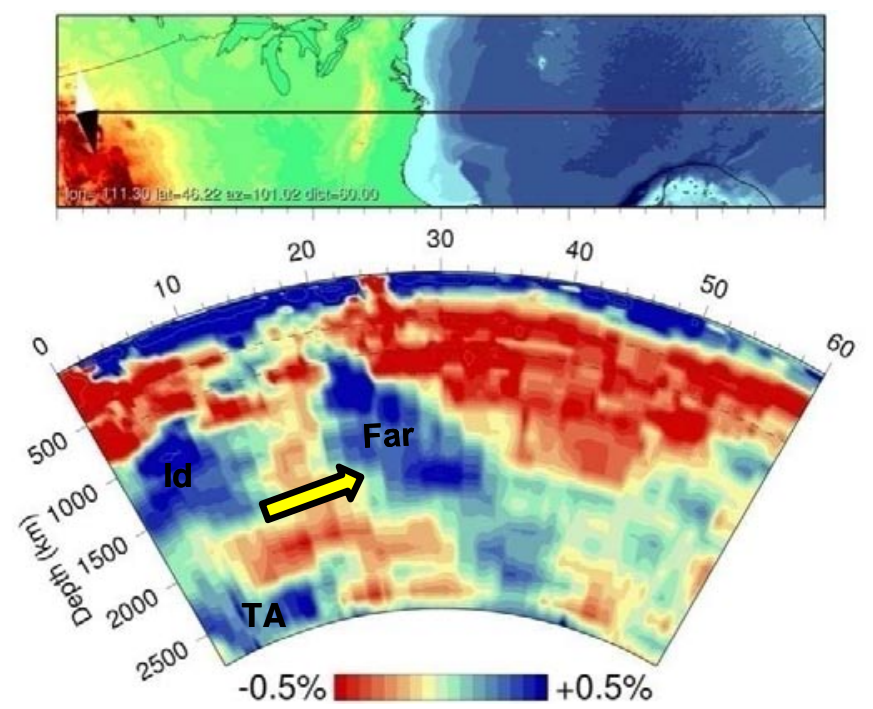

Supplementary Figure 3 Cross-sections of the tomographic model a) horizontal at $1500 \mathrm{~km}$ projected on Earth's surface $b$ ) vertical. The slab is indicated by arrows

The Farallon slab , as defined by Grand et al. (1997), is located below eastern Laurentia from the deep lower mantle to upper part of the lower mantle. The slab has been interpreted to represent eastward subducted Farallon oceanic lithosphere, however no consensus on timing exists, as estimates vary since $100 \mathrm{Myr}$ (Grand et al. (1997)), prior to $100 \mathrm{Ma}$ (Liu et al. (2008)), or since $150 \mathrm{Ma}$ (Sigloch et al. (2008). In the upper mantle the slab distintegrates into smaller, dispersed fragments, which have been associated with subduction during the Laramide orogeny (80-40 Ma) to present (Van der Lee and Nolet (1997), Sigloch et al. (2008)). We have adopted, in part, the interpretation of the F2 slab of Sigloch et al. (2008). They argued that subduction of the lower mantle Farallon slab, was interrupted due to the Laramide orogeny, hence the top of the Farallon slab to be latest Cretaceous to earliest Cenozoic in age and the rest of the slab to be up to late Jurassic in age. However, tectonic studies (Ward (1995), Nokleberg et al. (2000), DeCelles et al. 2009) indicate that subduction at the western margin of Laurentia was initiated earlier, from the early Jurassic (Nevadan orogeny ) onwards. This tectonic event is also simultaneous with the start of opening of the Atlantic Ocean. We interpret the early Jurassic event to represent the cause of the base of the slab. As a result the bulk of the slab is associated with late Jurassic-Cretaceous subduction during the Sevier orogeny (e.g. Ward (1995)).

- $\quad$ Derived midpoint (lon, lat, depth): -75 341690 


\section{SUPPLEMENTARY INFORMATION}

\section{$\mathrm{Ag}$ - Algeria}

a)

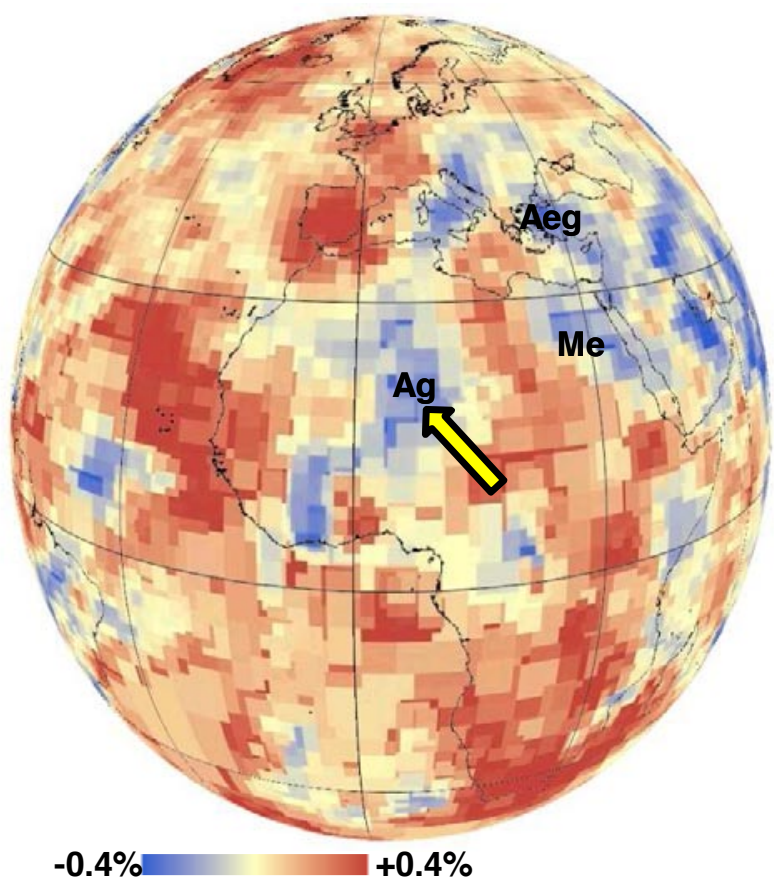

b)

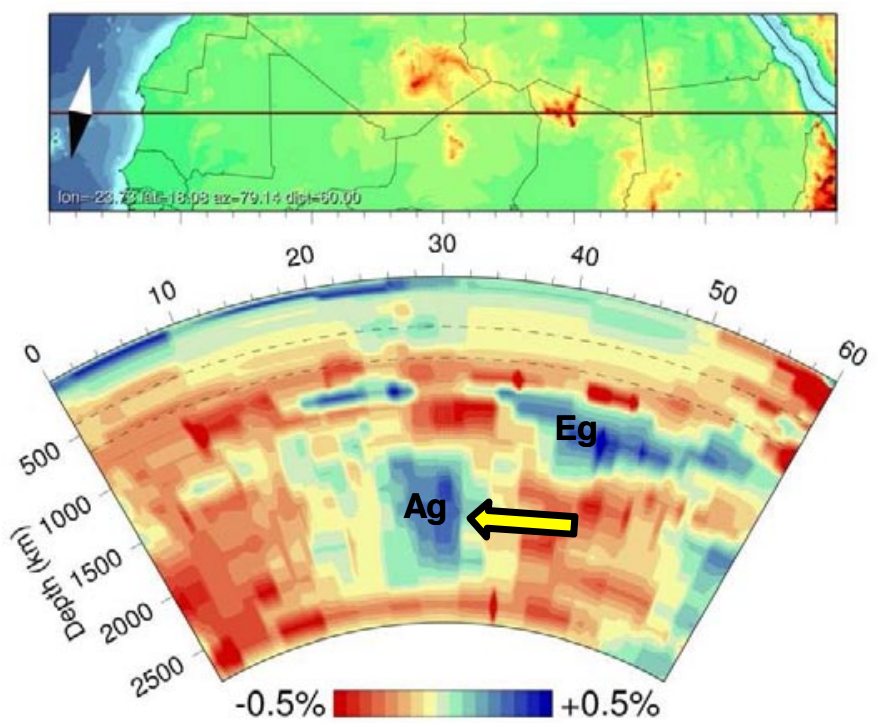

Supplementary Figure 4 Cross-sections of the tomographic model a) horizontal at $1900 \mathrm{~km}$ projected on Earth's surface $b$ ) vertical. The slab is indicated by arrows

The Algeria slab is located below NW Africa and the Mediterranean from the deep mantle up to mid-mantle. The neighbouring base of the $1^{\text {st }}$ order Aegean Tethys slab is used to infer that the Algeria slab represents Paleotethyan subducted lithosphere. The N-S trend is consistent with a possible origin of eastward subducted Maliac oceanic lithosphere of middle Mesozoic age. Stampfli and Borel (2004) infer subduction of Maliac Ocean lithosphere to have initiated at the western margin of the back-arc Vardar Ocean, starting in the middle Jurassic and ending in the late Jurassic-early Cretaceous by arc-continent collisions. In the north this was associated with a late Jurassic- early Cretaceous orogenic phase at the Strandja Massif (Okay et al. 2001).

- $\quad$ Derived midpoint (lon, lat, depth): 8211806

- $\quad$ Age slab (max-min): $168+/-13$ to $143+/-12 \mathrm{Ma}$

- $\quad$ Category: II, Region; Tethyan 


\section{Al - Aleutian}

a)

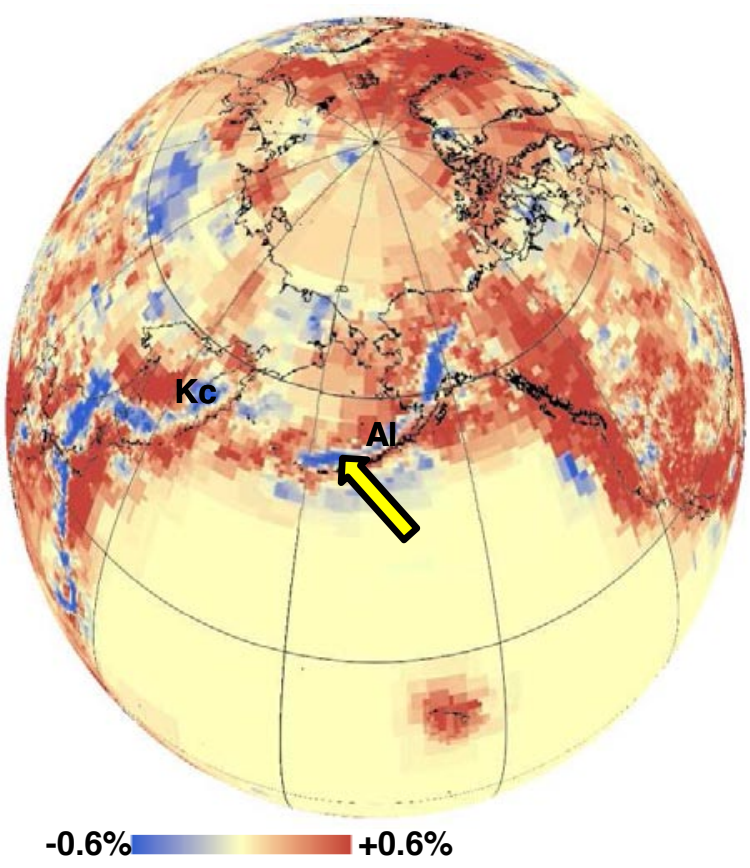

b)

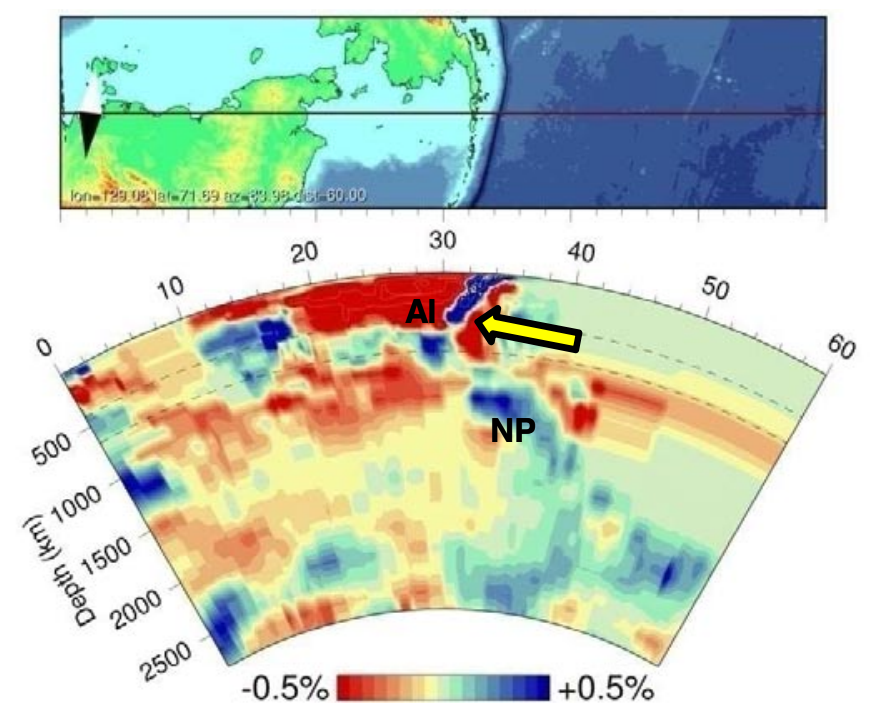

Supplementary Figure 5 Cross-sections of the tomographic model a) horizontal at $385 \mathrm{~km}$ projected on Earth's surface $b$ ) vertical. The slab is indicated by arrows

The Aleutian slab is located in the upper mantle below the southern Bering Sea and Alaska up to the surface in the Aleutian subduction zone. Two slabs below have been interpreted in the upper mantle, separated at $\sim 500 \mathrm{~km}$ depth (Qi et al. (2007), Gorbatov et al. (2000)). The shallow slab is interpreted to represent Pacific plate subduction since $43 \mathrm{Ma}$ (Qi et al. (2007)) or $48 \mathrm{Ma}$ (Gorbatov et al. (2000)), whereas the deeper slab (continuing into the lower mantle) is attributed to older subduction of the Kula plate (named Northern Pacific (NP) slab in our study). In our tomographic model the deepest part of the Aleutian slab is still clearly identifiable below $500 \mathrm{~km}$ depth and is continuous until the top of the lower mantle below southern Alaska. (Nokleberg et al. (2000)) infers an onset of magmatism in the Kluane arc at the southern margin of Alaska in the late Cretaceous to Eocene, which we have adopted as a time-range instead of a single onset event at 43 or $48 \mathrm{Ma}$.

- $\quad$ Derived midpoint (lon, lat, depth): -16557380

- Age slab (max-min): $68+/-16$ Ma to present

- Category: I, Region; Laurentian 


\section{At - Atlantis}

a)

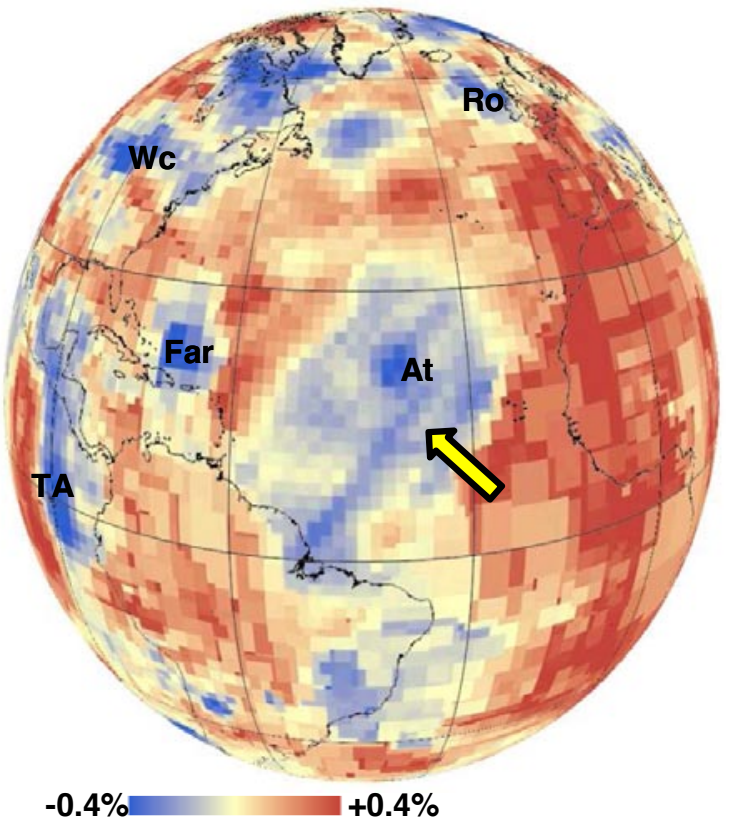

b)

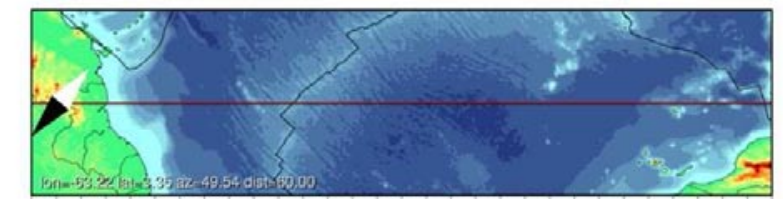

30



Supplementary Figure 6 Cross-sections of the tomographic model a) horizontal at 2650 km projected on Earth's surface b) vertical. The slab is indicated by arrows

The Atlantis slab is located below the central Atlantic and covers the CMB. It has not been defined in previous studies. The $1^{\text {st }}$ order Farallon slab higher in the mantle to the west leads us to infer a pre-Jurassic age of the Atlantis slab. Since there is no direct connection with the Farallon slab, three options exist for the origin of this slab. First, and most likely, the slab may result from eastward subduction below the western margin of Laurentia, as a pre-cursor of the Farallon slab. In the Permian to Triassic (Ziegler (1989), Ward (1995), Cawood and Buchan (2007)) the Sonoma orogeny took place at this location. We have interpreted this tectonic event to represent eastward subduction of Farallon/Panthalassa lithosphere at the continental margin causing the TA slab. No magmatism occurred at the western continental margin of Laurentia during the mid-late Triassic (Ward (1995), Nokleberg et al. (2000), Barbozo-Gudino et al. (2008) and DeCelles et al. (2009)) providing evidence for a time gap between the subduction of the Farallon and Atlantis slab. Assuming the base of the Farallon slab represents subduction at the continental margin in the early Jurassic, this indicates a middle to late Triassic westward displacement of LaurAsia by $2000 \mathrm{~km}$ to cross the spatial gap between the two slabs. In an alternative scenario, the Atlantis slab may represent lithosphere Permo-Triassic westward subducted PaleoTethys lithosphere below IberiaArmorica (Stampfli and Borel (2004)), but this scenario indicates $2000 \mathrm{~km}$ eastward displacement of LaurAsia during the middle to late Triassic. As a third scenario the slab may represent older, Carboniferous-early Permian subduction of Rheic oceanic lithosphere during the Variscan-Alleghanian orogeny (Ziegler (1989)) between Laurentia and NW GondwanaIberia-Armorica (Simancas et al. (2005), Stampfli and Borel (2004)). A Carboniferous age however would become an extreme outlier in the global dataset.

- $\quad$ Derived midpoint (lon, lat, depth): -39 222711

- $\quad$ Age slab (max-min): $285+/-5$ to $220+/-10 \mathrm{Ma}$

- Category: III, Region; Laurentian 


\section{Ba - Balkan}

a)

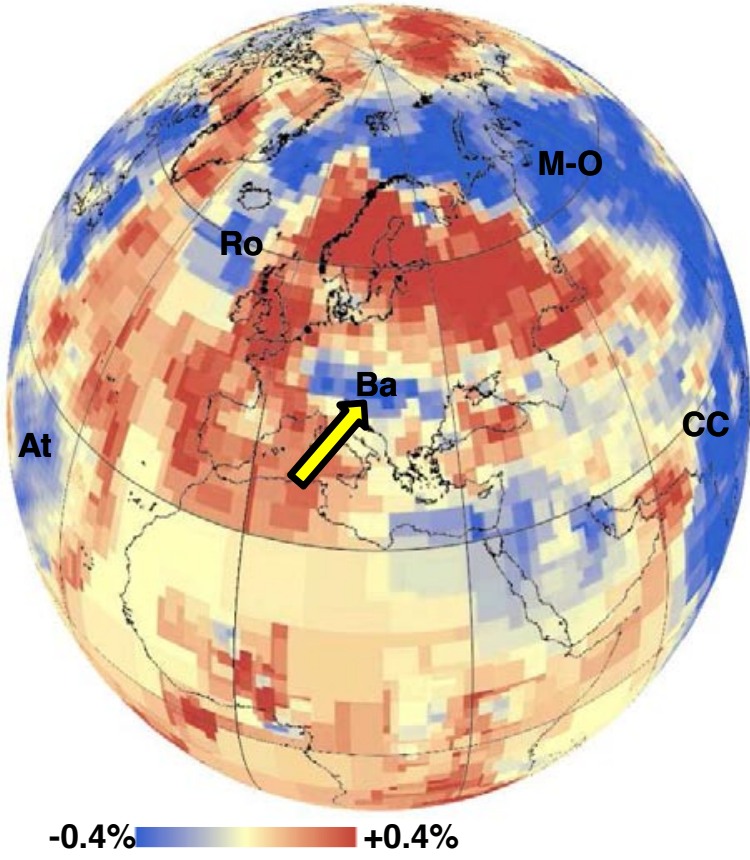

b)

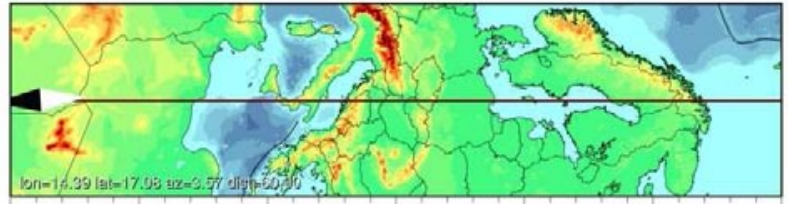

30

40

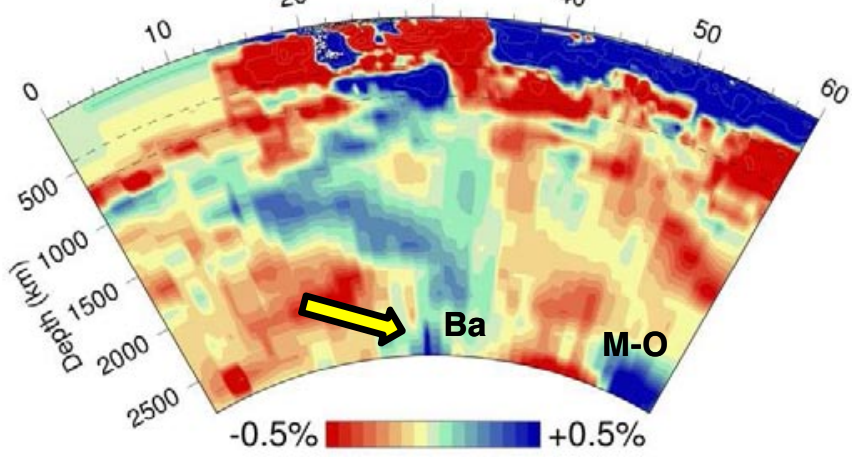

Supplementary Figure $\mathbf{7}$ Cross-sections of the tomographic model a) horizontal at $\mathbf{2 8 1 5} \mathrm{km}$ projected on Earth's surface $b$ ) vertical. The slab is indicated by arrows

The Balkan slab is located below south-eastern Europe, on the CMB. It has not been previously identified in tomographic studies. The $2^{\text {nd }}$ order Mesopotamia $(\mathrm{Me})$ slab and the $1^{\text {st }}$ order Mongol-Okhotsk slab to the northeast, both higher in the mantle, were used to infer that the Balkan slab represents subducted lithosphere of at least early Mesozoic age. The Mongol-Okhotsk subduction in the east constrains the Siberia block to a Permian to middle Jurassic position north of the Balkan slab. The Balkan slab therefore is likely the result of subduction at the southern margin of Siberia (western side at present), or at the eastern side of Kazakhstania (southern side at present). Most agree that in the late Palaeozoic and early Mesozoic northern and Central Asia was framed in the south by a north-dipping subduction zone and a related magmatic arc (Natal'in and Sengör (2005)). Stampfli and Borel (2004) inferred north-westward subduction of Solonker-Asiatic oceanic lithosphere, and suggests an onset of subduction at the southern margin of Siberia in the early Permian, ending in the late Triassic or end Permian (Cocks and Torsvik (2007)), by accretion of the Tarim block, which may provide an age range for this slab. Alternatively, the slab may (partly) be the result of the Permian closure of the Uralian Ocean or to pre-Permian subduction.

- $\quad$ Derived midpoint (lon, lat, depth): 17472711

- Age slab (max-min): $270+/-10$ to $210+/-10 \mathrm{Ma}$

- $\quad$ Category: III, Region; Other 


\section{Bf - Beaufort}

a)

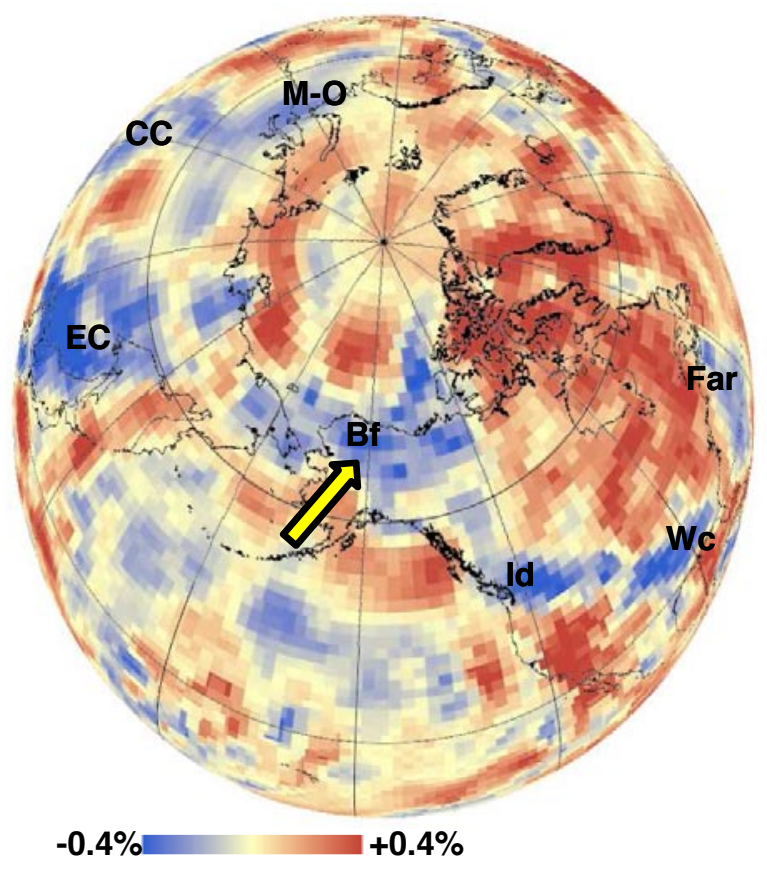

b)
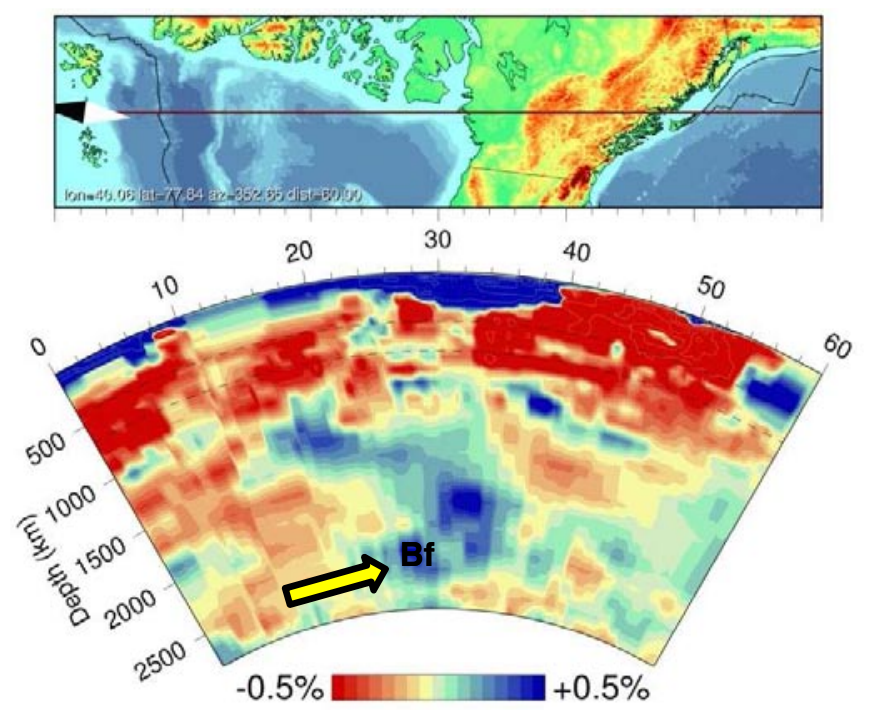

Supplementary Figure 8 Cross-sections of the tomographic model a) horizontal at $2300 \mathrm{~km}$ projected on Earth's surface b) vertical. The slab is indicated by arrows

- The Beaufort slab is located below North Alaska and the Arctic Ocean within the deep mantle. It has not been interpreted before. The base of the $1^{\text {st }}$ order Mongol-Okhotsk slab across the North Pole, as well as the base of the $2^{\text {nd }}$ order Idaho (Id) slab to the south, was used to infer that the Beaufort slab represents subducted Arctic lithosphere of likely early or middle Mesozoic age. Nokleberg et al. (2000) reconstructed subduction of Arctic/Panthalassa lithosphere at the Alazeya arc during the late Triassic-Jurassic, and forms agewise the most likely candidate for this slab. Golonka et al. (2003) infers subduction to have occurred in this region from the Triassic to late Cretaceous and the equivalent Alazeya arc is interpreted to accrete/evolve into a complex configuration of several minor subduction zones by the early Cretaceous.

- $\quad$ Derived midpoint (lon, lat, depth): -128 722383

- Age slab (max-min): $219+/-11$ to $154+/-10 \mathrm{Ma}$

- Category: III, Region; Laurentian 


\section{Ca - Caribbean}

a)

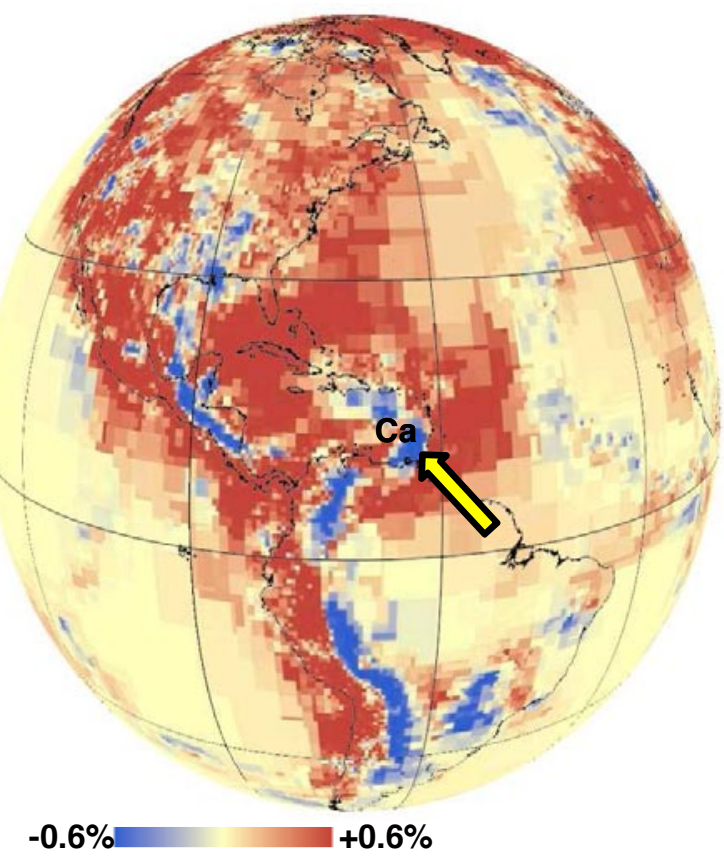

b)

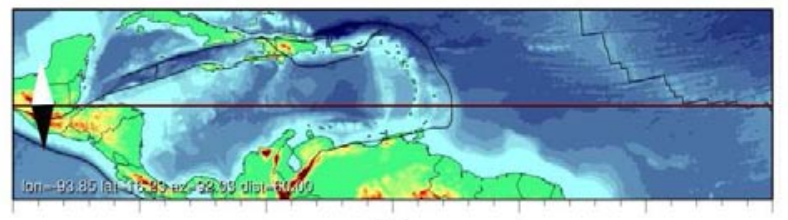

20

$30 \quad 40$

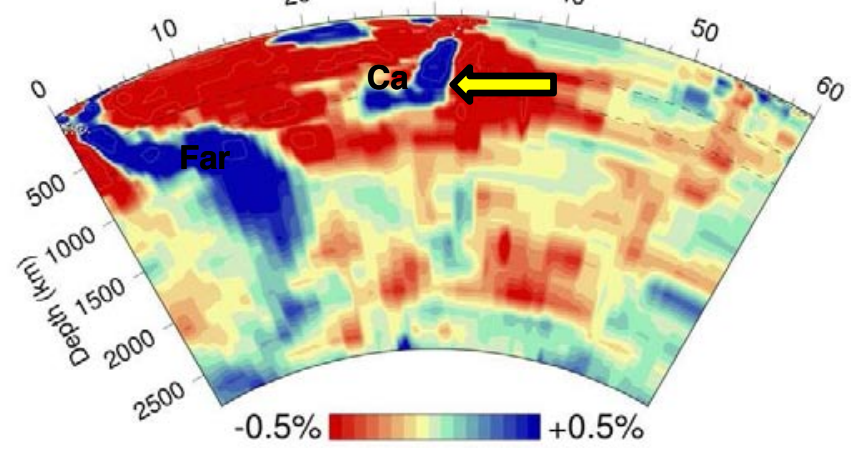

Supplementary Figure 9 Cross-sections of the tomographic model a) horizontal at $440 \mathrm{~km}$ projected on Earth's surface b) vertical. The slab is indicated by arrows

The Caribbean slab is located in the upper mantle below the eastern Caribbean plate up to the surface at the Lesser Antilles subduction zone where Atlantic oceanic lithosphere subducts westward. The slab dips steeply from the surface to a depth of $600 \mathrm{~km}$, changing to a sub-horizontal position below this depth (Van der Hilst and Spakman (1989)). We interpreted the base of the slab to be upper CretaceousPaleocene, based on the onset of the formation of the Lesser Antilles arc (Burke (1988), Ross and Scotese (1988)). At the base of the slab there is a connection with a slab of a different orientation (see Venezuela (VE) slab), which we attribute to an earlier subduction phase below the Greater Antilles, ending in the late Cretaceous (García-Casco et al. (2008a\&b), Krebs et al. (2008)).

- $\quad$ Derived midpoint (lon, lat, depth): -63 13380

- $\quad$ Age slab (max-min): 66 +/- 7 Ma to present

- Category: I, Region; Laurentian 


\section{CC - Central China}

a)

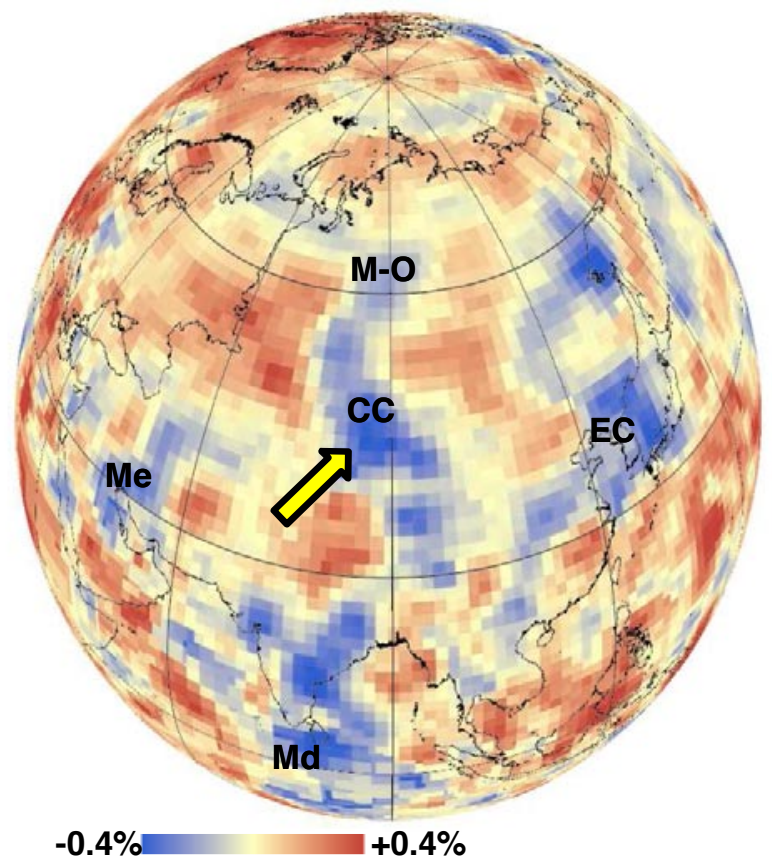

b)
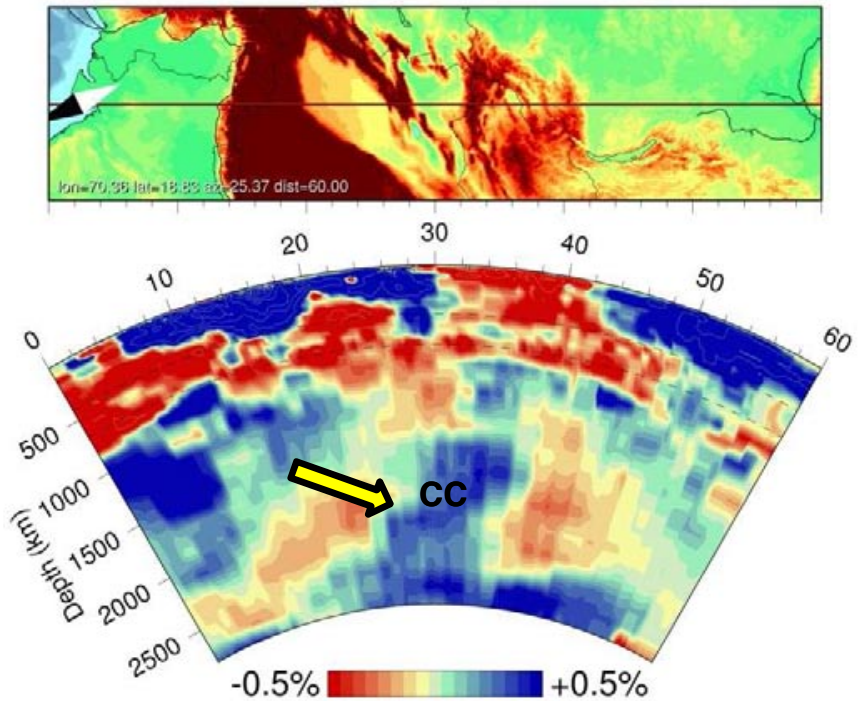

Supplementary Figure 10 Cross-sections of the tomographic model a) horizontal at $2100 \mathrm{~km}$ projected on Earth's surface $b$ ) vertical. The slab is indicated by arrows

- $\quad$ The Central China slab is located below central Asia from the CMB up to the midmantle. We have re-interpreted the southern part of the Z-shaped anomaly with respect to van der Voo et al. (1999a) to be the remnant of eastward subducted PaleoTethys lithosphere below Cathaysia and named this the CC slab - contrary to the northern part of the Z-shaped anomaly which represents Mongol-Okhotsk lithosphere (van der Voo et al. (1999a)), as pointed out in the description of the Mongol-Okhotsk slab. Based on the interpretation of 1st-order Mongol Okhotsk slab to the north, the age of the CC slab is likely early to middle Mesozoic. Stampfli and Borel (2004) indicate that subduction of PaleoTethys lithosphere at the CC-slab's latitudes initiated at the western margin of Cathaysia in the late Permian-early Triassic, ending in the early late Cretaceous.

- $\quad$ Derived midpoint (lon, lat, depth): 88452135

- $\quad$ Age slab (max-min): $255+/-5$ to $103+/-19 \mathrm{Ma}$

- Category: II, Region; Cathaysian 


\section{Ch - Chukchi}

a)

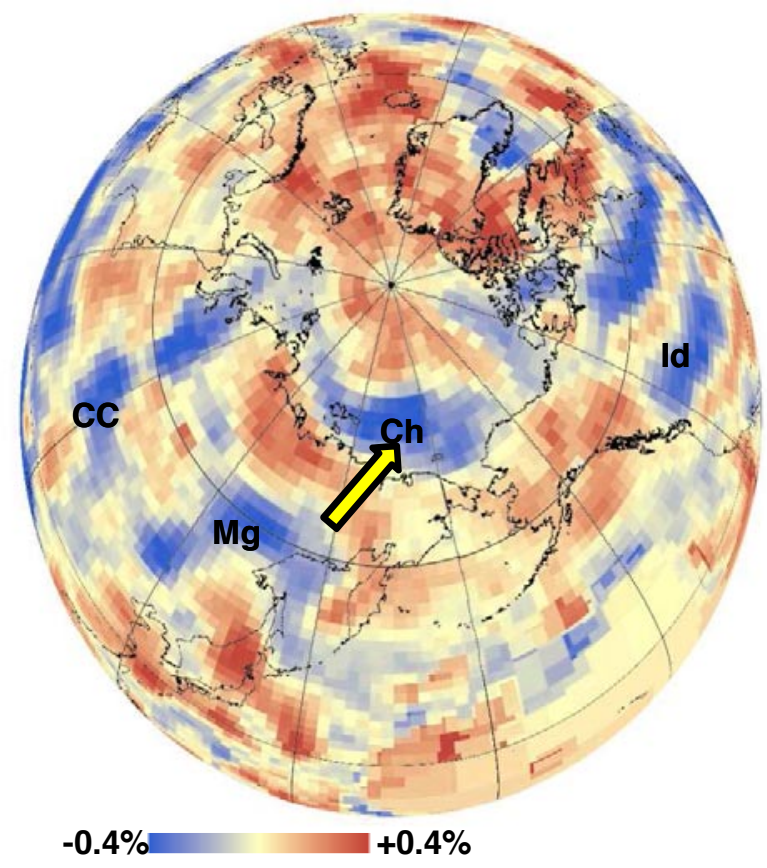

b)


Supplementary Figure 11 Cross-sections of the tomographic model a) horizontal at $1500 \mathrm{~km}$ projected on Earth's surface $b$ ) vertical. The slab is indicated by arrows

The Chukchi slab is located below North Siberia and the Arctic Ocean within the midmantle. It has not been interpreted before in previous studies. The $2^{\text {nd }}$ order Mongolia (Mg) slab to the south suggests that the Chukchi slab represents Arctic lithosphere of middle to late Mesozoic age. Subduction of Arctic lithosphere initiated at the northern margin of Laurentia at the Koyukuk arc (Nokleberg et al. (2000), Golonka et al. (2003)), starting in the late Jurassic and ending in the early Cretaceous, which we adopt as the age range of the Chukchi slab.

Derived midpoint (lon, lat, depth): 170771525

Age slab (max-min):154 +/- 10 to $110+/-10 \mathrm{Ma}$

Category: III, Region; Laurentian 


\section{EC - East China}

a)

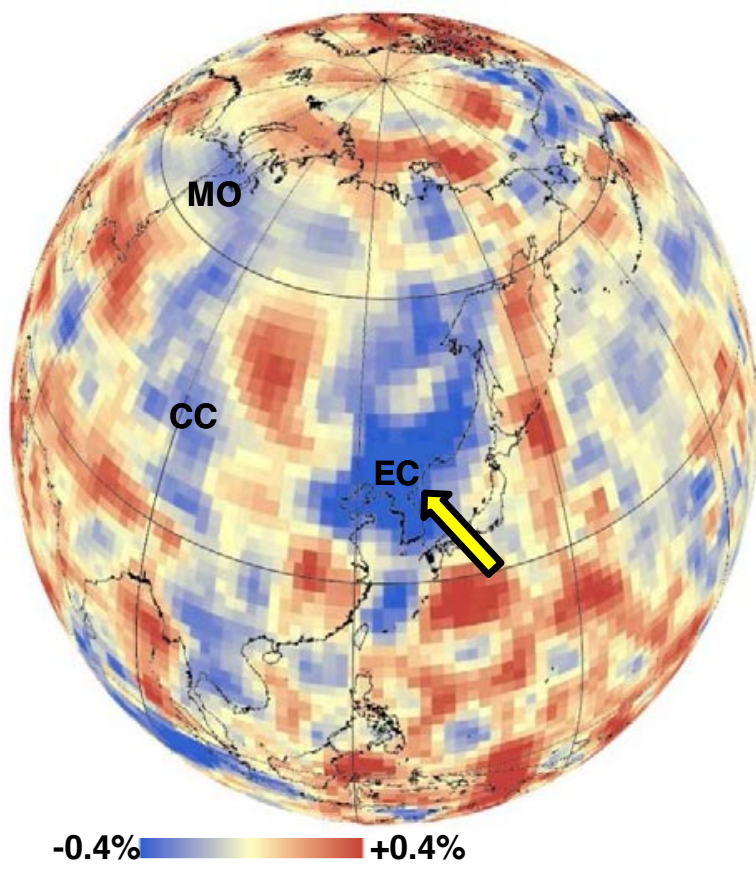

b)
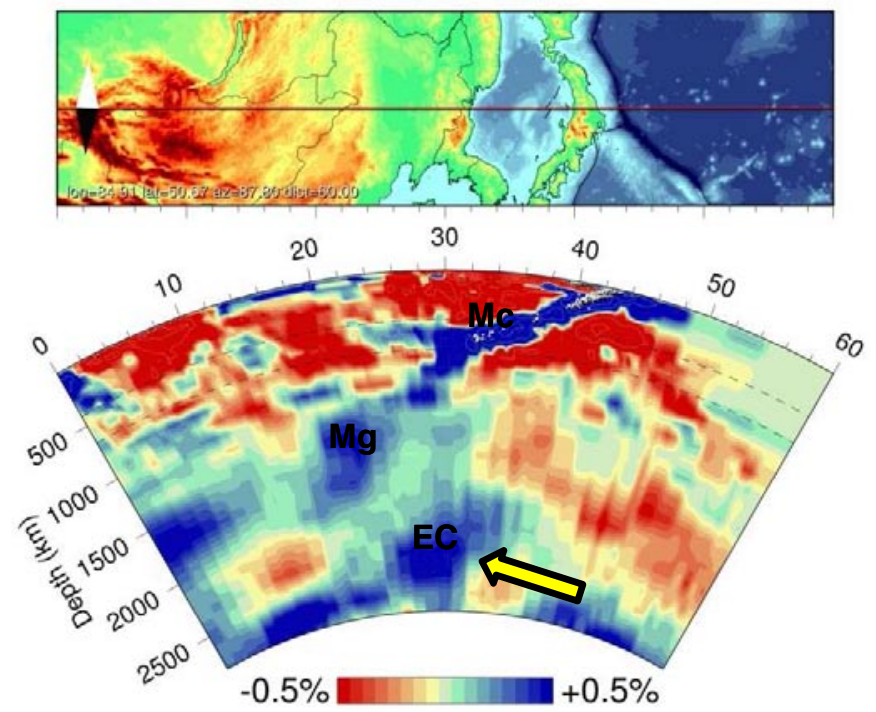

Supplementary Figure 12 Cross-sections of the tomographic model a) horizontal at $2300 \mathrm{~km}$ projected on Earth's surface $b$ ) vertical. The slab is indicated by arrows

The East China slab is located below eastern Asia from the CMB up to the deep mantle. In previous tomographic studies it has been referred to as the Pacific slab (van der Voo et al. (1999a)), which resulted from westward subduction of paleoPacific (Panthalassa) lithosphere at the east-Asian margin. The depth of the top and base of the $1^{\text {st }}$ order Mongol-Okhotsk slab towards the north lead us to interpret the age of the East China slab to be early-middle Mesozoic. Sagong et al. (2005) state three magmatic phases to have occurred in the Korean peninsula, in the Triassic, early to middle Jurassic and since the late Cretaceous (see Manchuria (Mc) slab). The age gap between the first two phases is considered small (13 Ma) and not significant within the resolution of our method and we therefore use these two phases to estimate the timing of subduction.

- $\quad$ Derived midpoint (lon, lat, depth): 128432329

- $\quad$ Age slab (max-min): $248+/-5$ to $158+/-5 \mathrm{Ma}$

- Category: II, Region; Cathaysian 


\section{Eg - Egypt}

a)

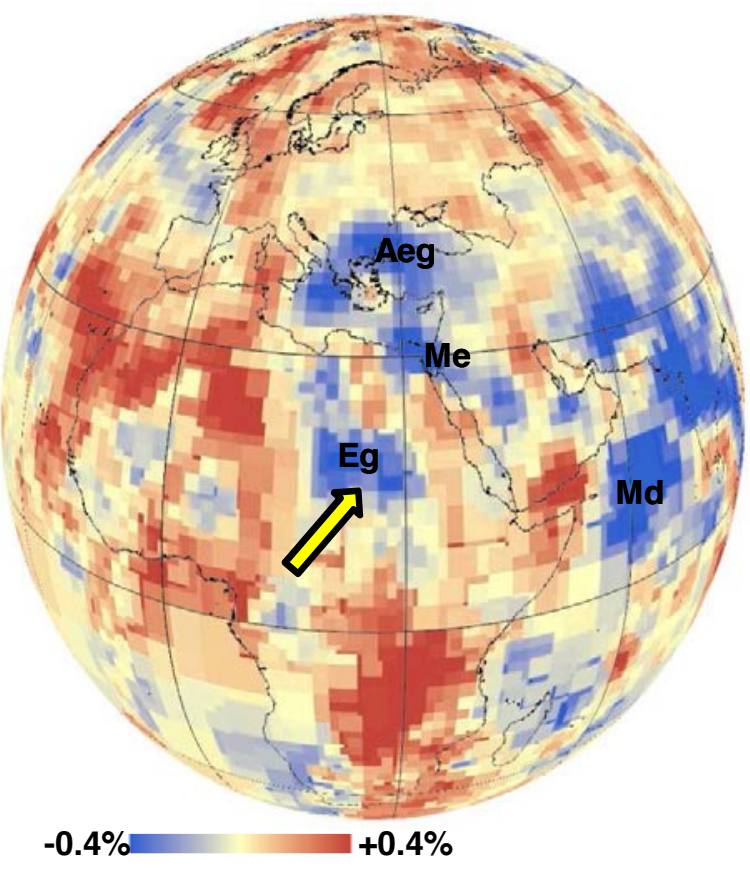

b)

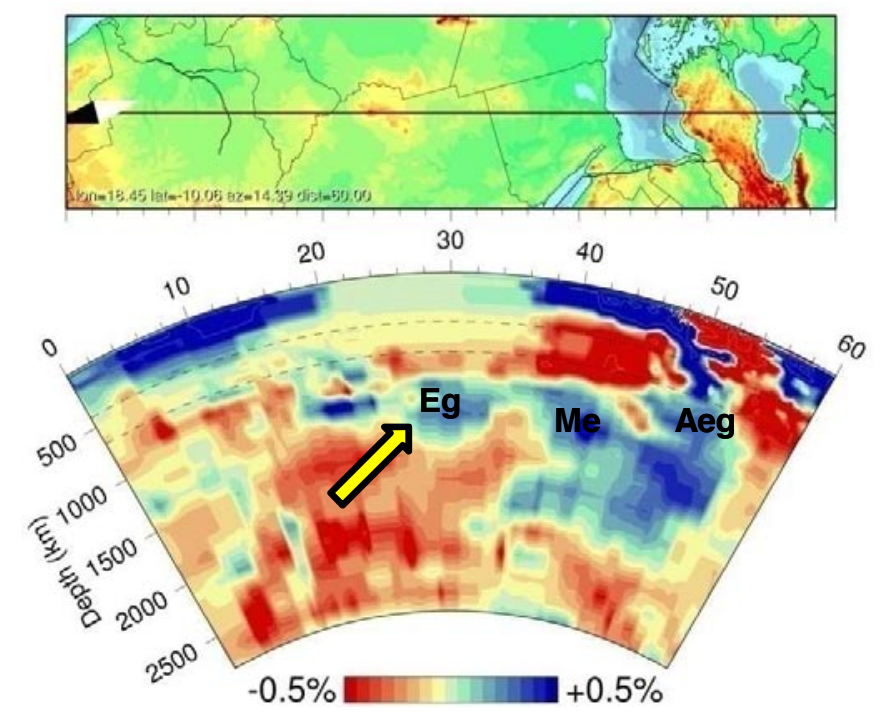

Supplementary Figure 13 Cross-sections of the tomographic model a) horizontal at $1175 \mathrm{~km}$ projected on Earth's surface $b$ ) vertical. The slab is indicated by arrows

The Egypt slab is located below North Africa in the mid-mantle. We have adopted the name from Hafkenscheid et al. (2006). The $1^{\text {st }}$ order Aegean Tethys slab to the north, the $2^{\text {nd }}$ order Mesopotamia $(\mathrm{Me})$ slab in the east and $2^{\text {nd }}$ order Algeria $(\mathrm{Ag})$ slab towards the west were used to infer that the Egypt has likely a late Mesozoic age. Stampfli and Borel (2004) indicate an active margin with eastward subduction at the east of the Antalya-Semail (Taurides) terrane in middle to late Cretaceous, prior to its collision with the Sakarya terrane (Pontides) in the early Cenozoic.

- $\quad$ Derived midpoint (lon, lat, depth): 26191139

- $\quad$ Age slab (max-min): $103+/-19$ to $77+/-7 \mathrm{Ma}$

- Category: III, Region; Tethyan 


\section{GI - Georgia Islands}

a)

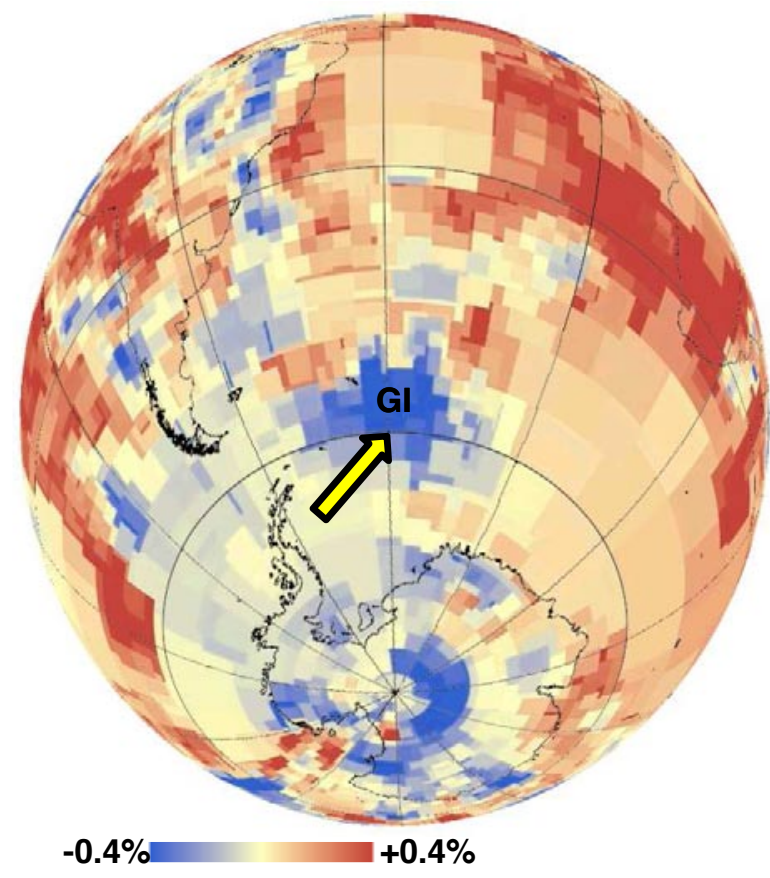

b)
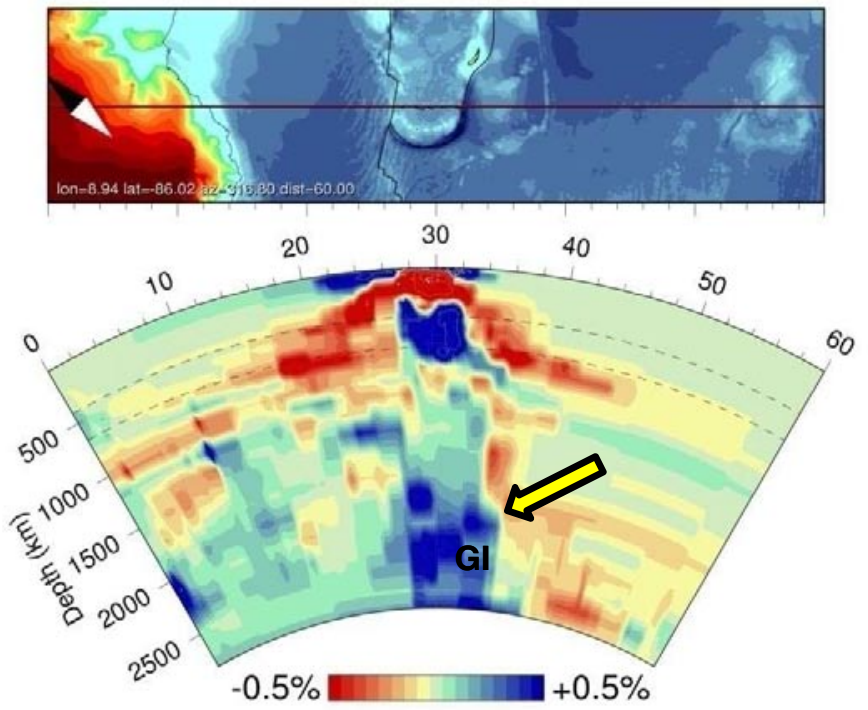

Supplementary Figure 14 Cross-sections of the tomographic model a) horizontal at $2300 \mathrm{~km}$ projected on Earth's surface b) vertical. The slab is indicated by arrows

The Georgia Islands slab is located below the southern Atlantic and Antarctic Oceans from the CMB up to the deep mantle. It has not been previously been identified in tomographic studies. Based on the global interpretation of $1^{\text {st }}$ and $2^{\text {nd }}$ order slabs a pre-Mesozoic to middle Mesozoic origin is expected. Based on qualitative assessments of slabs in the deep mantle, constraining Gondwana on either side, a subduction zone at southern Gondwana is the most likely cause. We have inferred subduction of oceanic lithosphere, causing Permian-Triassic magmatism in along southern Gondwana (Cawood and Buchan (2007), Ramos (2008)) during the Gondwanide orogeny, to be the most likely cause of the slab. Subduction in the area re-iniated more westerly in the Jurassic-Cretaceous, causing back-arc spreading (Martin (2007)), which we associate with the weaker, more westerly anomaly in the mid mantle.

- $\quad$ Derived midpoint (lon, lat, depth): $-30-572429$

- $\quad$ Age slab (max-min): $290+/-5$ to $205+/-15 \mathrm{Ma}$

- Category: III, Region; Other 


\section{Hi - Himalayas}

a)

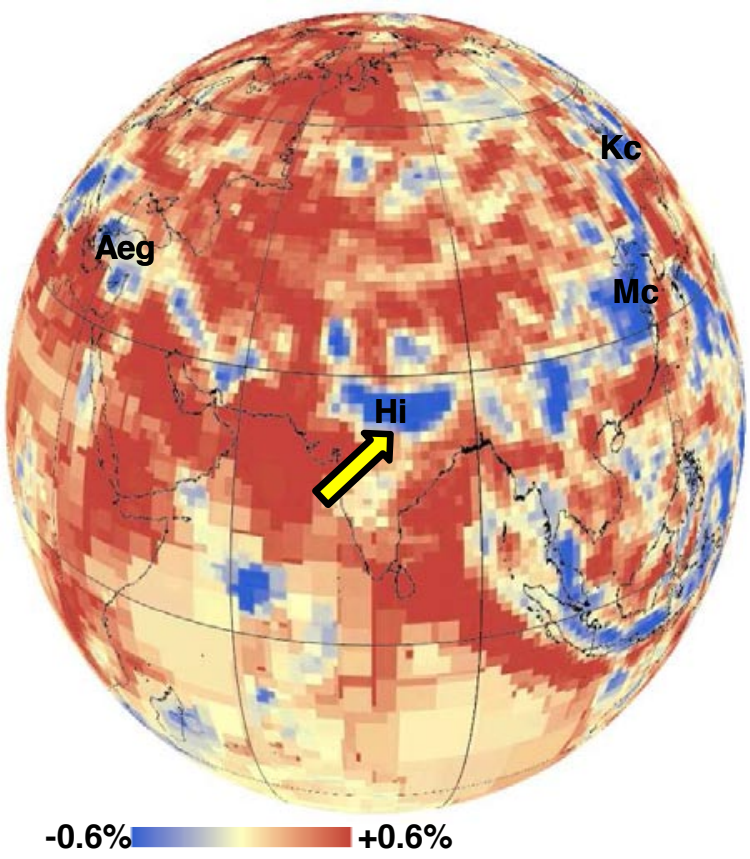

b)
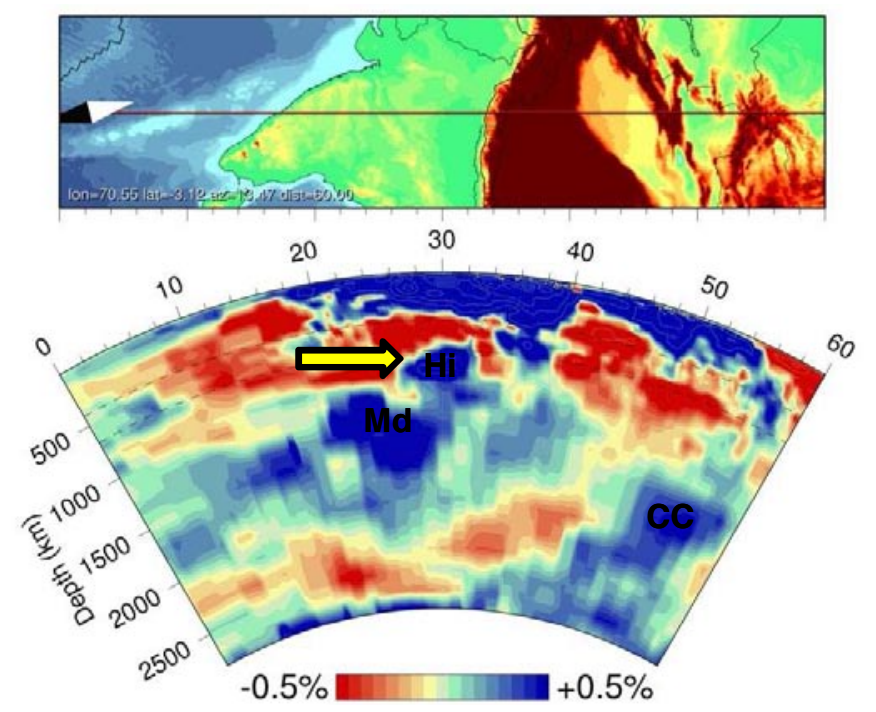

Supplementary Figure 15 Cross-sections of the tomographic model a) horizontal at $710 \mathrm{~km}$ projected on Earth's surface $b$ ) vertical. The slab is indicated by arrows

The Himalayas slab is located below the northern part of the Indian plate from the upper part of the lower mantle up to the upper mantle. In previous tomographic studies it has been referred to as the IV (van der Voo et al.(1999)) or Hi anomaly (Hafkenscheid et al. (2006)). It consists of NeoTethys lithosphere, specified as Spongtang (Hafkenscheid et al. (2006)), that subducted northward at the Eurasian margin, starting in the early Cenozoic. Stampfli and Borel (2004) show the opening and subduction of the Spongtang back-arc ocean to occur from the late Cretaceous onwards, accompanied by the formation of a northward verging foreland basin (Leier et al. (2007)), which we adopted as the potential start of subduction. After IndiaEurasia collision subduction stalled and ended with slab detachment in the EoceneMiocene.

Derived midpoint (lon, lat, depth): 7826789

- Age slab (max-min): $82+/-3$ to $32+/-12 \mathrm{Ma}$

- Category: II, Region; Tethyan 


\section{Id - Idaho}

a)

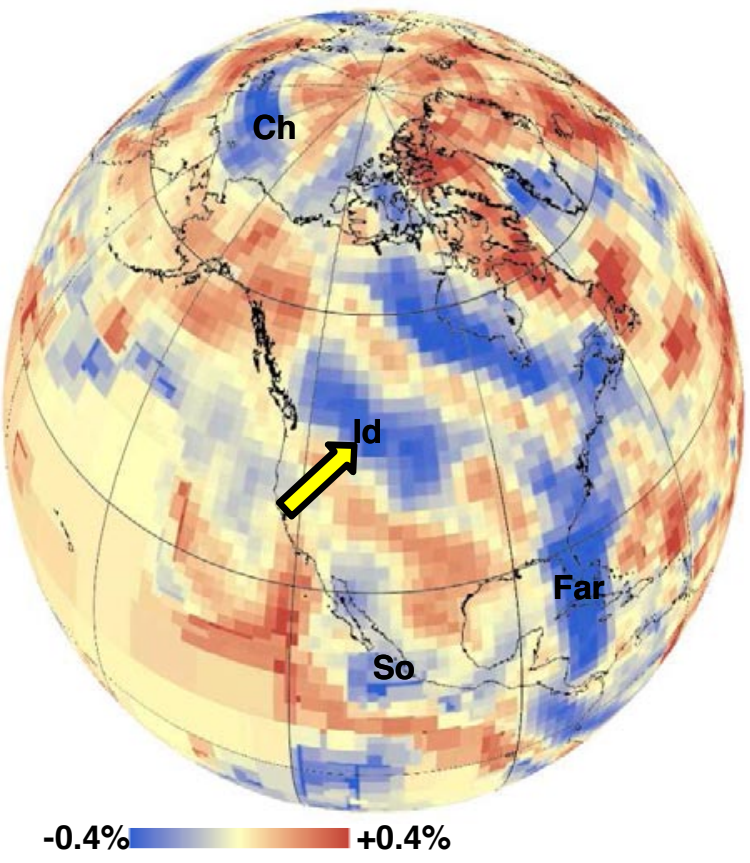

b)
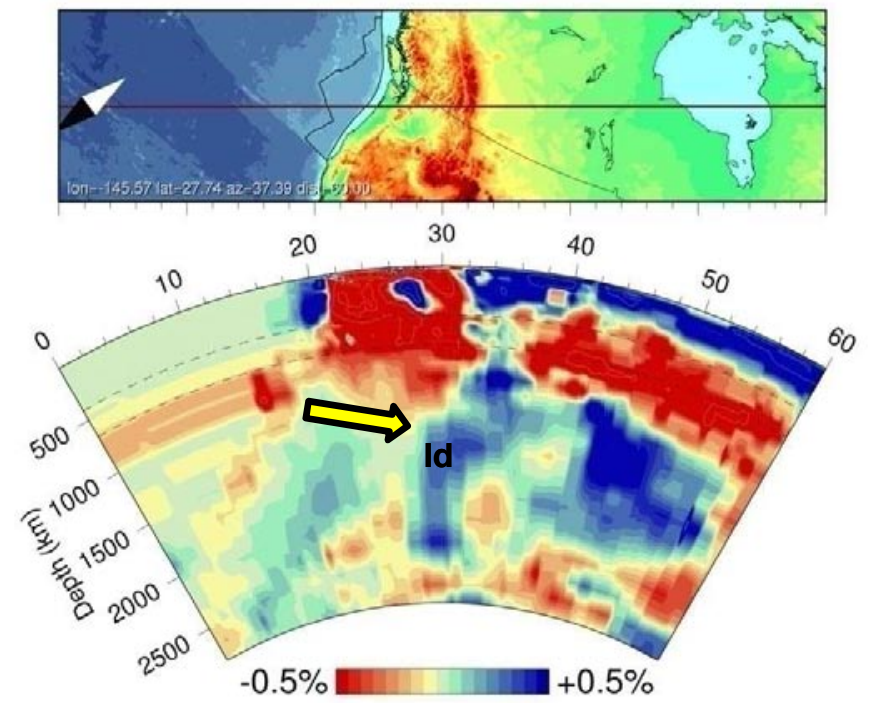

Supplementary Figure 16 Cross-sections of the tomographic model a) horizontal at $1500 \mathrm{~km}$ projected on Earth's surface b) vertical. The slab is indicated by arrows

The Idaho slab is located below western Laurentia from the deep mantle up to upper part of the lower mantle. In previous tomographic studies it has been interpreted as Cenozoic Farallon lithosphere (S2 slab in Sigloch et al. (2008)) or Cretaceous Kula or Izanagi lithosphere (Ren et al. (2007)). Based on our (older) interpretation of the $1^{\text {st }}$ order Farallon slab to the east, we infer that the Idaho slab represents subducted Farallon/Panthalassa lithosphere of middle to late Mesozoic age range. Since the Id slab is located at similar depths but west of the Farallon slab, we have adopted an intra-oceanic origin for this slab. This interpretation differs from Sigloch et al (2008), who associated the slab with subduction at the Laurentian continental margin since 70-50 Ma. Nokleberg et al. (2000) suggested that northward to eastward subduction of Farallon/Panthalassa lithosphere occurred at the intra-oceanic (northern part of) Wrangellia superterrane, starting in the early to middle Jurassic. Accretion of the terrane with Laurentia started in the late Jurassic (Trop et al. (2005)) and ended in the early to late Cretaceous (Nokleberg et al. (2000)).

- $\quad$ Derived midpoint (lon, lat, depth): -118491628

- $\quad$ Age slab (max-min): $186+/-23$ to $92+/-8 \mathrm{Ma}$

- Category: II, Region; Laurentian 


\section{Kc - Kamchatka}

a)

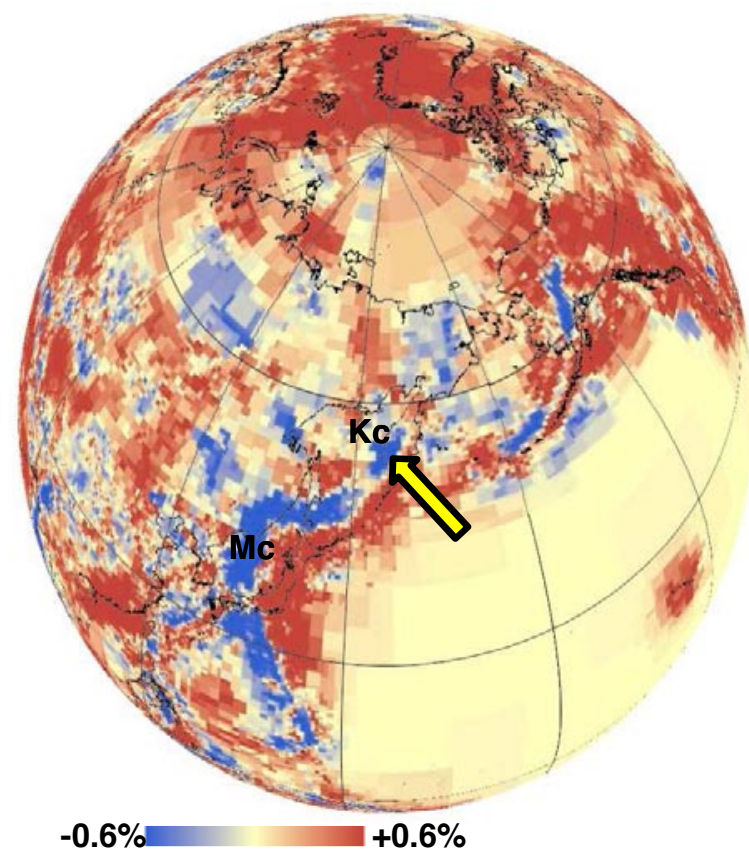

b)

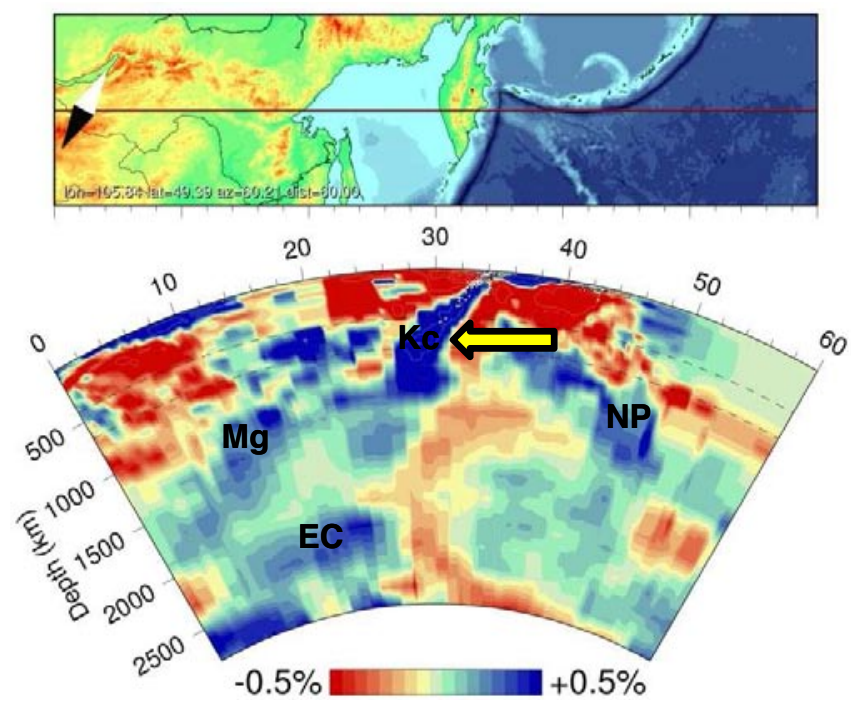

Supplementary Figure 17 Cross-sections of the tomographic model a) horizontal at $440 \mathrm{~km}$ projected on Earth's surface b) vertical. The slab is indicated by arrows

The Kamchatka slab is located below the Sea of Okhotsk from the Kamchatka-Kuriles subduction zone at surface down to the upper part of the lower mantle and is associated with north-westward subduction of the Pacific plate (Gorbatovet al. (2000), Jiang et al. (2009)). The part of the slab below $660 \mathrm{~km}$ discontinuity has been interpreted to have an age of at least 65-55 Ma (Gorbatov et al. (2000)). Nokleberg et al. (2000) and Golonka et al. (2003) propose that the onset of westward subduction at the later Kamchatka block (Olyutorka arc) started in the middle to late Cretaceous.

This is supported by the formation of the accretionary wedge from the Late Cretaceous onwards (Alexeiev et al. (2006)).

- $\quad$ Derived midpoint (lon, lat, depth): 15555433

- $\quad$ Age slab (max-min): 92 +/- 8 Ma to present

- Category: I, Region; Cathaysian 


\section{Mc - Manchuria}

a)

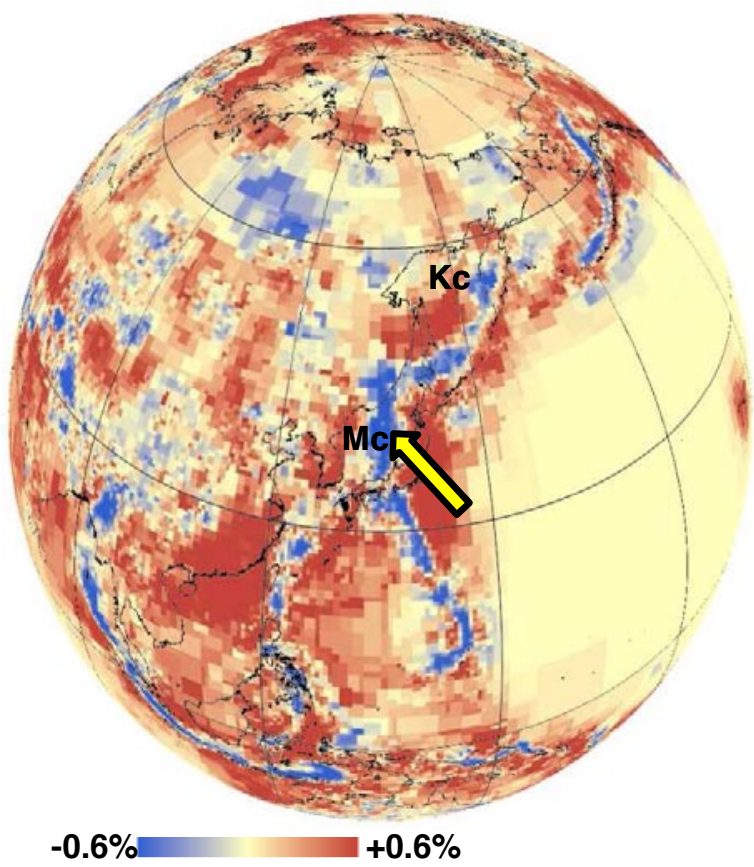

b)


Supplementary Figure 18 Cross-sections of the tomographic model a) horizontal at $385 \mathrm{~km}$ projected on Earth's surface b) vertical. The slab is indicated by arrows

The Manchuria slab is located from the Japan subduction zone at surface, nearhorizontal at the transition zone and below east Asia it is found down to the upper part of the lower mantle (van der Hilst et al.(1991), Fukao et al. (2001), Miller and Kennett (2006), Abdelwaheed and Zhao (2007)). It has previously been associated with westward subduction of the Pacific and Philippine Sea plate starting around 40-45 Ma (van der Hilst et al. (1991), Abdelwaheed and Zhao (2007)). This timing was based on the evolution of the Philippine plate only, whereas the Manchuria slab is located north of the Philippine Ocean plate subduction. This timing we thus render not representative. Instead, we prefer an earlier start of subduction, indicated by a South Korean late Cretaceous-Eocene magmatic phase, following a magmatic lull (Sagong et al. (2005)). We have interpreted this phase to represent the onset of subduction of the Manchuria slab, which continues to the present day. This is in agreement with the simultaneous onset of late Cretaceous subduction in the north, associated with the Sakhalin slab (see below).

- $\quad$ Derived midpoint (lon, lat, depth): 13546433

- $\quad$ Age slab (max-min): $80+/-30$ Ma to present

- Category: I, Region; Cathaysian 


\section{Md - Maldives}

a)

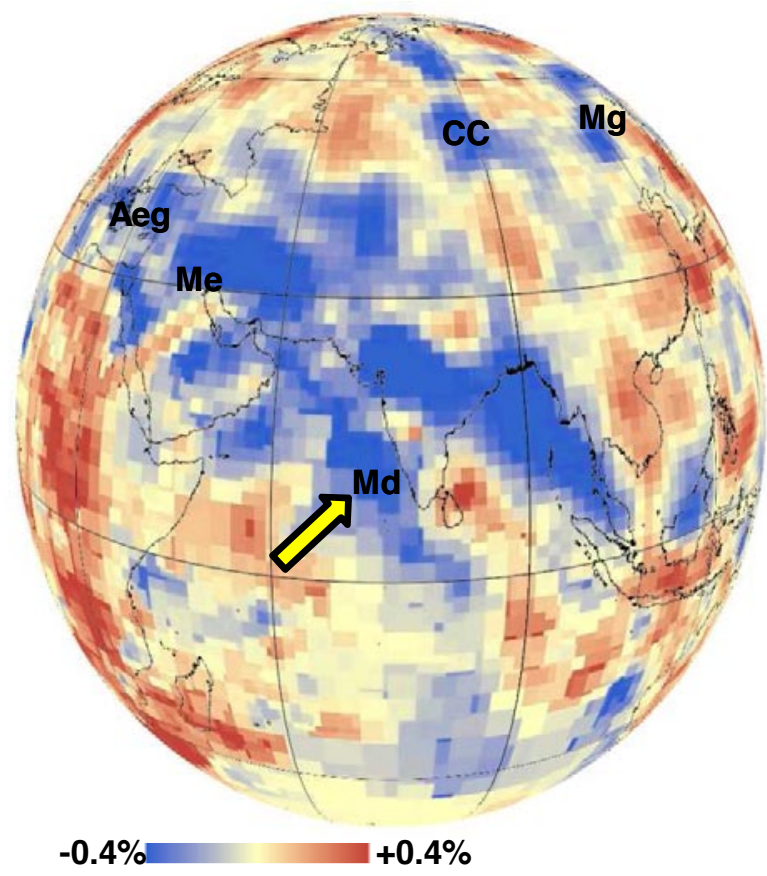

b)

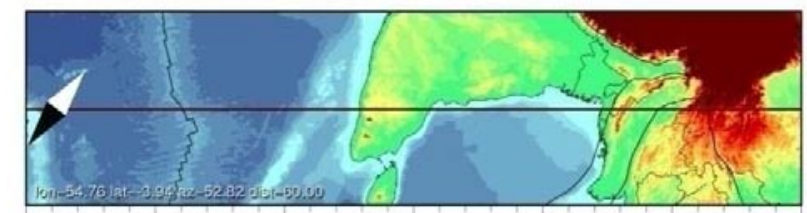

$30 \quad 40$

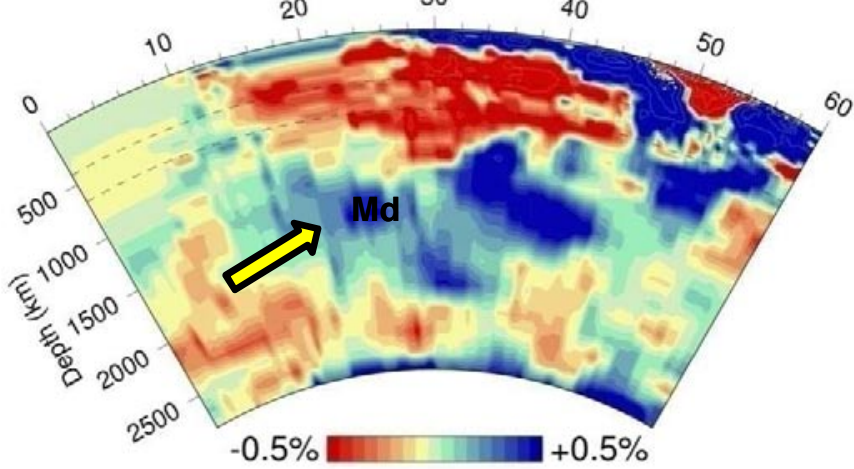

Supplementary Figure 19 Cross-sections of the tomographic model a) horizontal at $1500 \mathrm{~km}$ projected on Earth's surface b) vertical. The slab is indicated by arrows

The Maldives slab is located below the north-western Indian Ocean from the deep mantle up to the upper part of the lower mantle. In previous tomographic studies it has been referred to as the eastern part of the III (van der Voo et al. (1999) or IO anomaly (Hafkenscheid et al. (2006)), as a result of northward subducting NeoTethys lithosphere below the Spongtang ocean and Lhasa block during the Cretaceous and earliest Cenozoic (van der Voo et al.(1999), Hafkenscheid et al. (2006)). An earlier late Triassic start of northward subduction is stated by Stampfli and Borel (2004) and Roger et al. (2008), which we adopted as the start of NeoTethys subduction leading to the slab formation.

- $\quad$ Derived midpoint (lon, lat, depth): 79141533

- Age slab (max-min): $210+/-10$ to $64+/-7 \mathrm{Ma}$

- Category: II, Region; Tethyan 


\section{Me - Mesopotamia}

a)

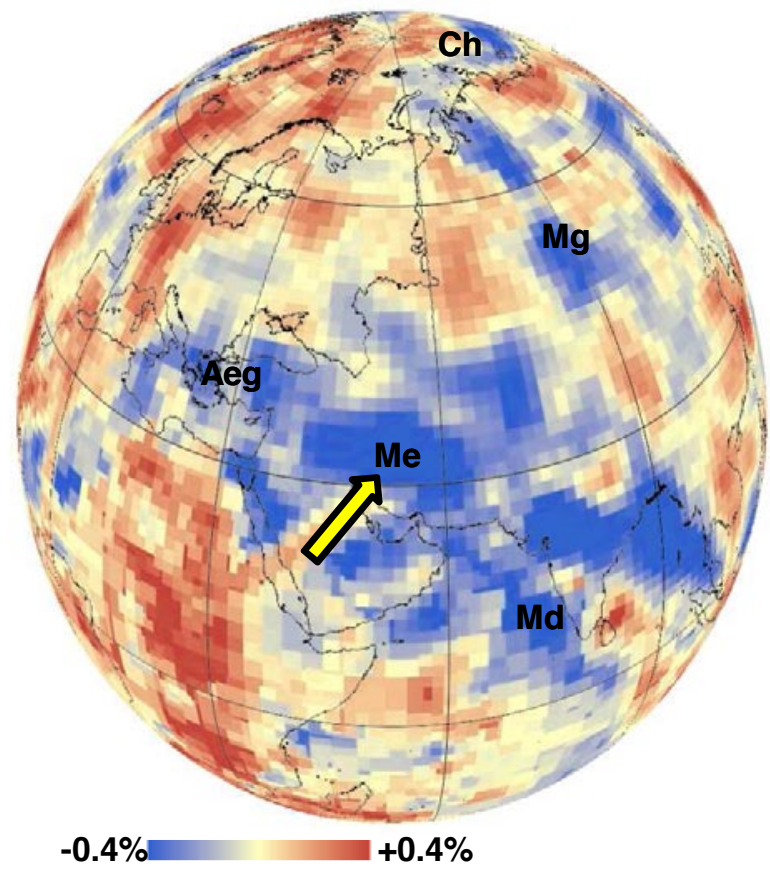

b)
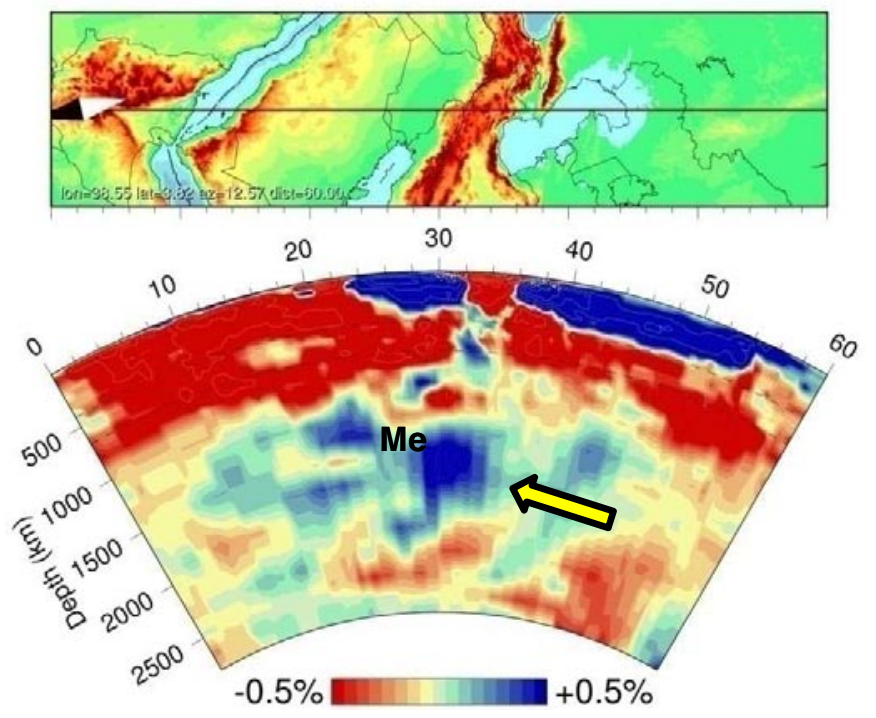

Supplementary Figure 20 Cross-sections of the tomographic model a) horizontal at $1500 \mathrm{~km}$ projected on Earth's surface b) vertical. The slab is indicated by arrows

The Mesopotamia slab is located below the Arabian plate from the deep mantle up to mid-mantle. In previous studies it has been referred to as the western part of the III slab (van der Voo et al. (1999)) or the Eg \& Sa anomalies (Hafkenscheid et al. (2006)), as a result of northward subducting NeoTethyan lithosphere (van der Voo et al.(1999)), below the Semail Ocean (Hafkenscheid et al. (2006)). We have adopted the late Triassic as the earliest possible onset of NeoTethys subduction, ending in the late Cretaceous (Stampfli and Borel (2004), Warren et al. (2003)).

Derived midpoint (lon, lat, depth): 46331654

Age slab (max-min): $210+/-10$ to $77+/-7 \mathrm{Ma}$

Category: II, Region; Tethyan 


\section{Mg - Mongolia}

a)



b)

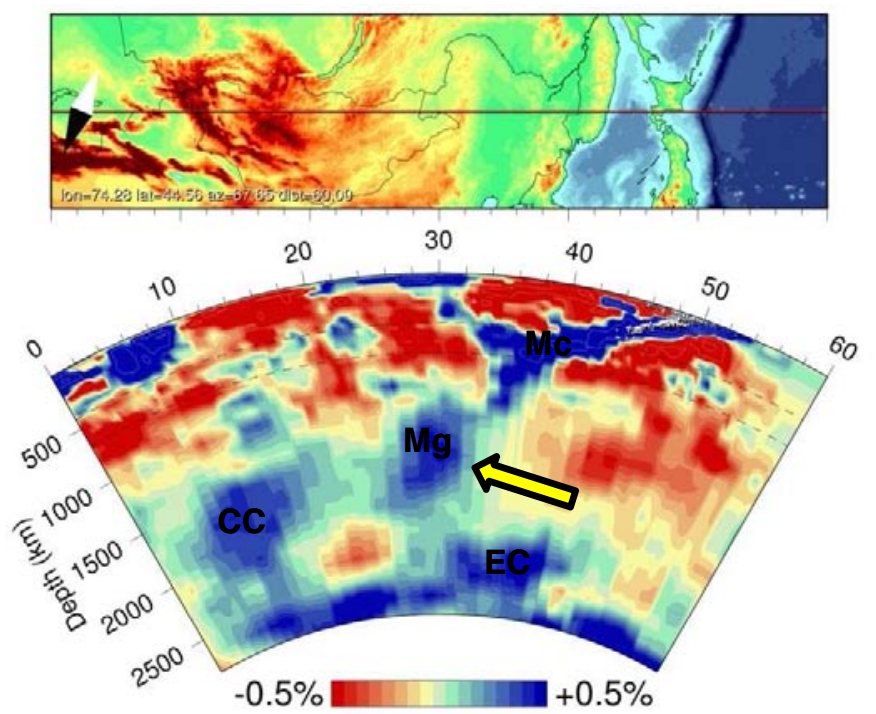

Supplementary Figure 21 Cross-sections of the tomographic model a) horizontal at $1325 \mathrm{~km}$ projected on Earth's surface b) vertical. The slab is indicated by arrows

The Mongolia slab is located below north-eastern Asia within the mid-mantle. In previous studies it has been referred to as a Pacific slab (van der Voo et al.(1999)). We use the $1^{\text {st }}$ order slabs of Kamchatka (higher in the mantle) and Mongol-Okhotsk slab (lower in the mantle) to infer that the Mongolia slab represents (westward) subducted Pacific lithosphere with middle to late Mesozoic age range. Nokleberg et al. (2000) and Golonka (2003) state westward subduction of Pacific lithosphere at the north-eastern margin of Asia, associated with the Monakin-Khingan arcs, starting in the early-middle Jurassic and ending in the early Cretaceous.

- $\quad$ Derived midpoint (lon, lat, depth): 118481454

Age slab (max-min): $178+/-15$ to $110+/-10 \mathrm{Ma}$

Category: II, Region; Cathaysian 


\section{SUPPLEMENTARY INFORMATION}

\section{NP - North Pacific}

a)

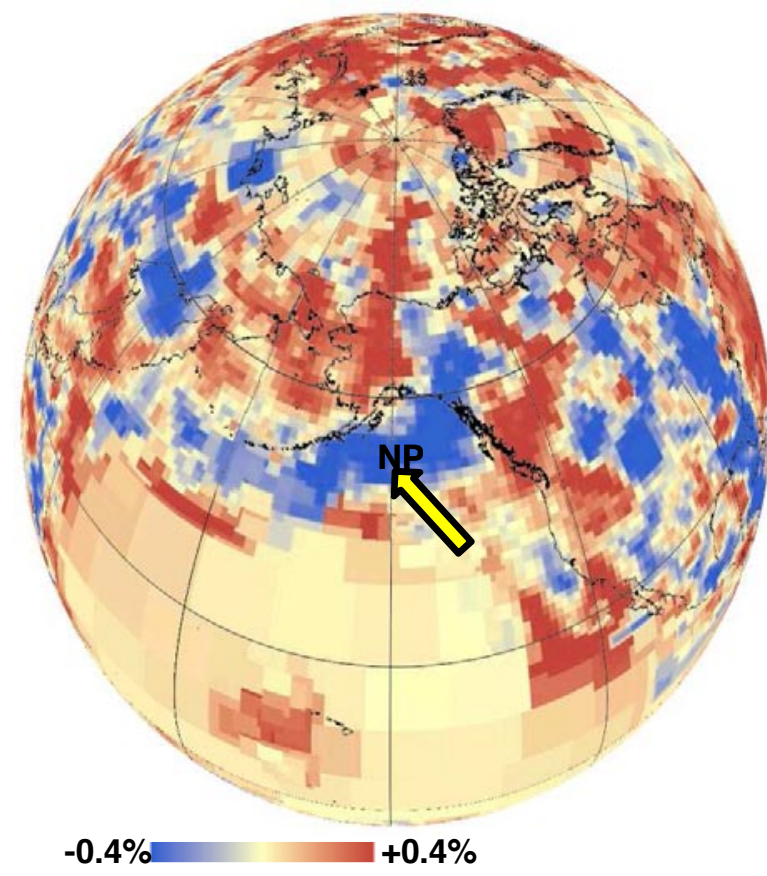

b)
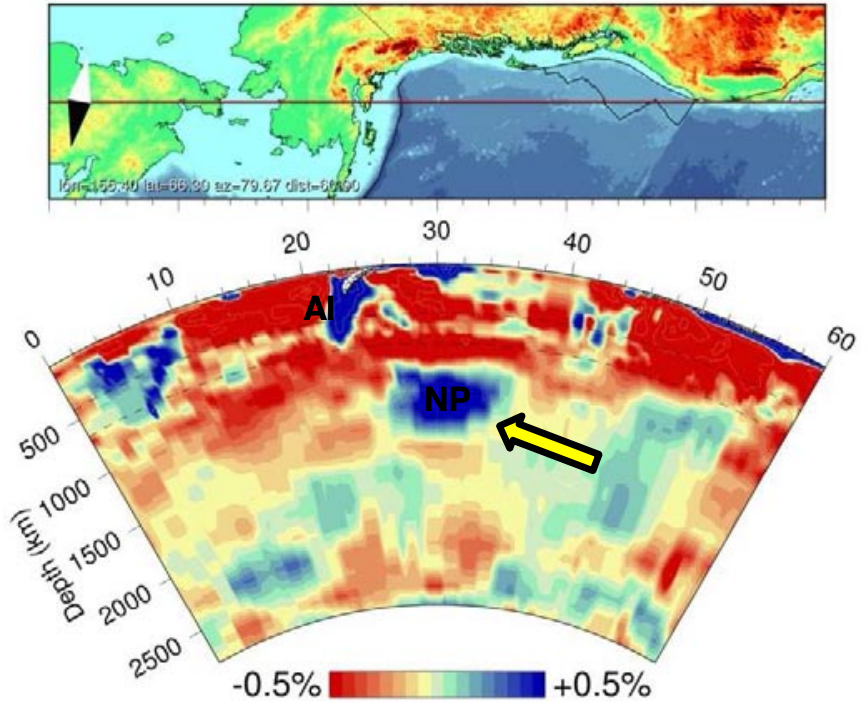

Supplementary Figure 22 Cross-sections of the tomographic model a) horizontal at $1040 \mathrm{~km}$ projected on Earth's surface b) vertical. The slab is indicated by arrows

The North Pacific slab is located below the northern Pacific to southern Alaska from the mid-mantle up to upper part of the lower mantle. In previous tomographic studies it has been referred to as the Kula (Qi et al. (2007)) or Pacific slab (Ren et al. (2007)). The $1^{\text {st }}$ order Aleutian slab higher in the mantle to the north leads us to infer that the North Pacific slab represents pre-Cenozoic subducted lithosphere. In agreement with the latitude of the slab, Engebretson et al. (1985) states northward subduction of Izanagi and Farallon lithosphere below the Kula plate to have initiated at an intraoceanic subduction zone in the early Cretaceous, ending in the late Cretaceous.

- $\quad$ Derived midpoint (lon, lat, depth): -14356 1180

- $\quad$ Age slab (max-min): $125+/-15$ to $95+/-15 \mathrm{Ma}$

- Category: III, Region; Other 


\section{Ro - Rockall}

a)

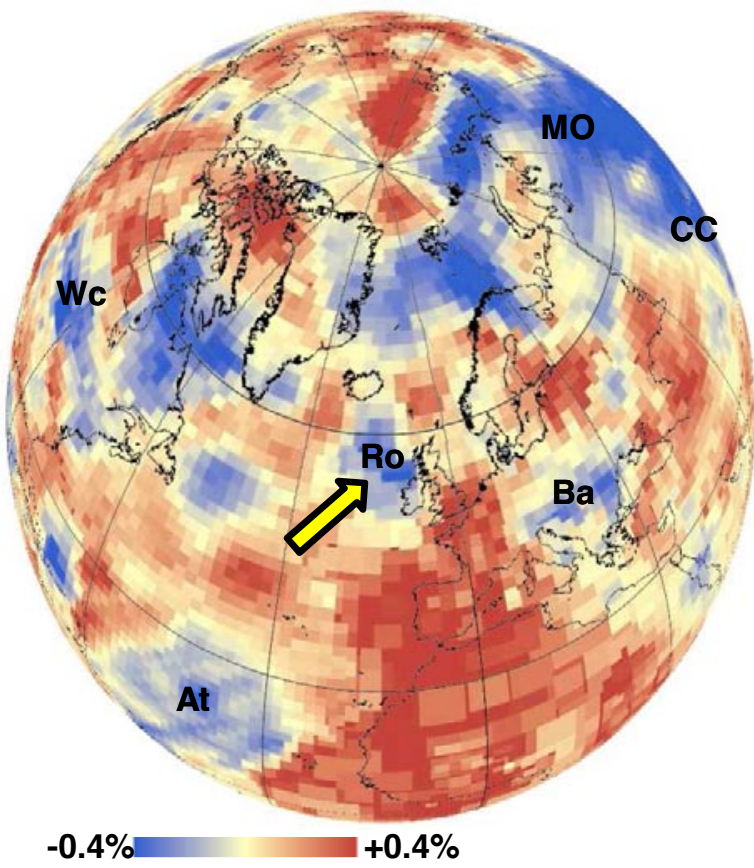

b)

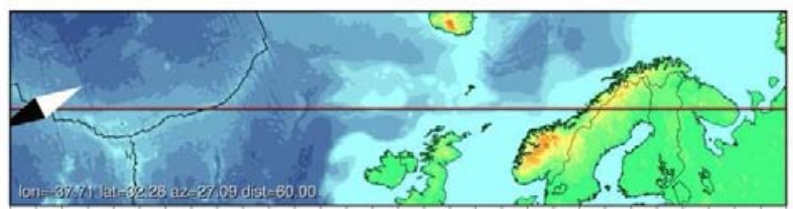

30

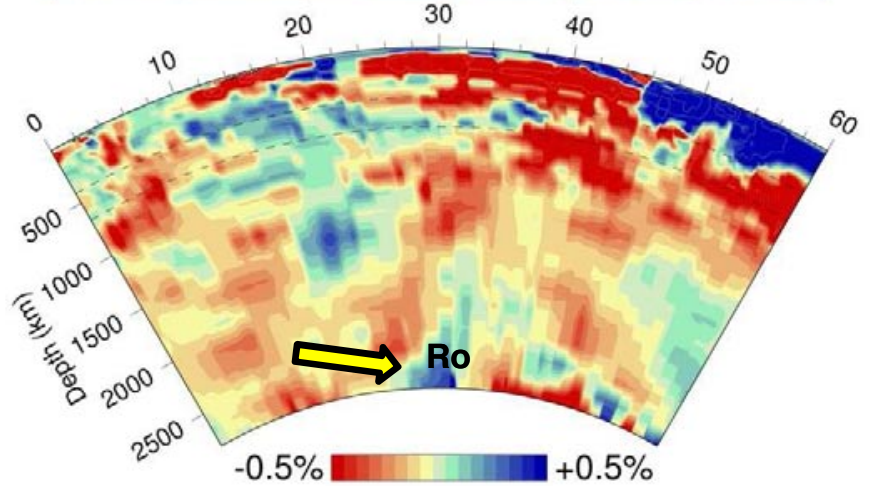

Supplementary Figure 23 Cross-sections of the tomographic model a) horizontal at $2650 \mathrm{~km}$ projected on Earth's surface b) vertical. The slab is indicated by arrows

The Rockall slab is located below westernmost Europe /north eastern Atlantic Ocean on top of the CMB. It has not been previously interpreted in tomographic studies. The $1^{\text {st }}$ order Mongol-Okhotsk slab to the east, the $2^{\text {nd }}$ order Wichita slab to the west and the $3^{\text {rd }}$ order Balkan slab to the southeast were used to infer that the Rockall slab represents subducted paleo-Arctic lithosphere between Siberia and Laurussia of at least early Mesozoic age. Stampfli and Borel (2004) interpret subduction of the Anjui ocean at the western margin of Siberia (north of Siberia at present), starting in the early-late Permian and ending in the late Triassic or end Permian (Cocks and Torsvik (2007)).

- $\quad$ Derived midpoint (lon, lat, depth): -13 572711

- $\quad$ Age slab (max-min): $270+/-10$ to $225+/-5 \mathrm{Ma}$

- $\quad$ Category: III, Region; Other 


\section{Sa - Sakhalin}

a)

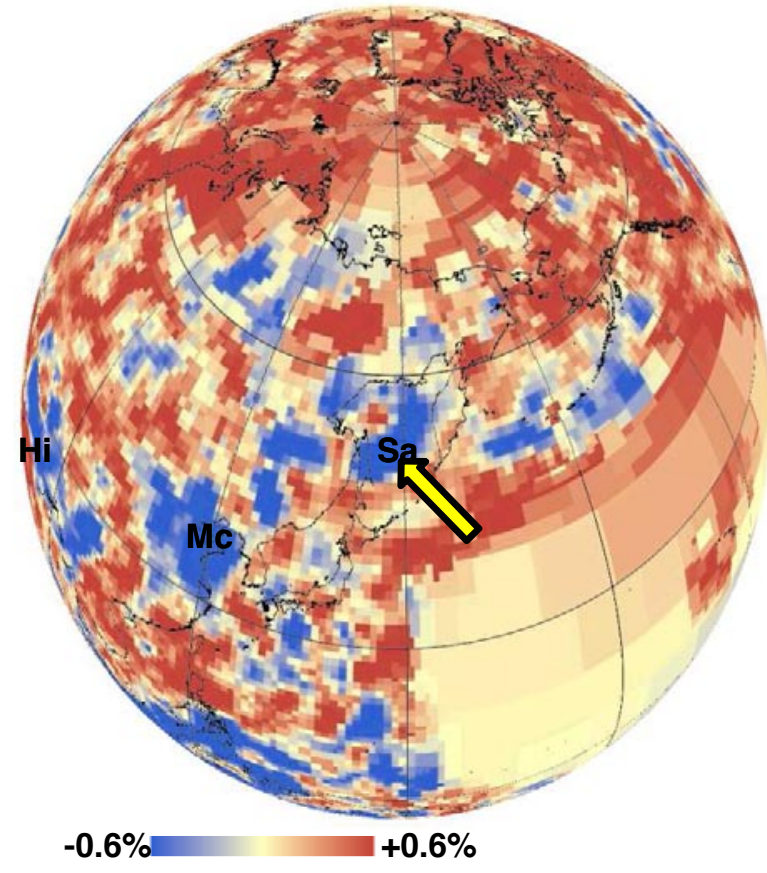

b)

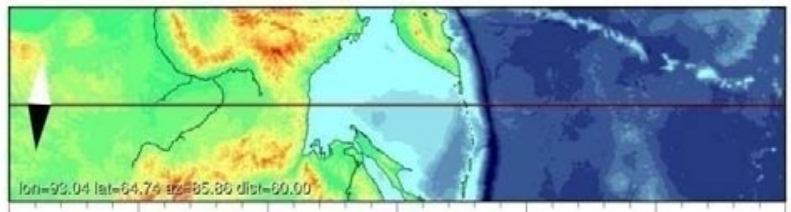

30

40

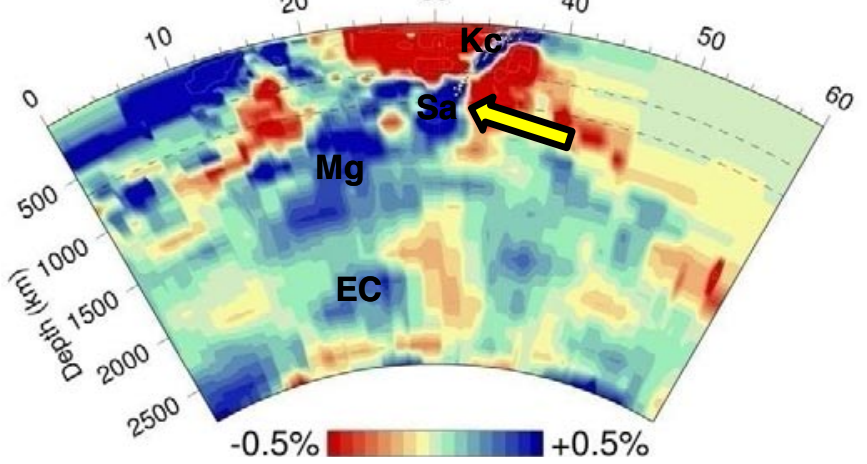

Supplementary Figure 24 Cross-sections of the tomographic model a) horizontal at $810 \mathrm{~km}$ projected on Earth's surface b) vertical. The slab is indicated by arrows

The Sakhalin slab is located below north-eastern Asia within the upper part of the lower mantle. In previous tomographic studies it has been referred to as a subducted slab of the Okhotsk plate (Gorbatov et al. (2000)). The $1^{\text {st }}$ order Kamchatka slab to the east and shallower was used to infer that the Sakhalin slab likely has a late Mesozoic to early Cenozoic age. Nokleberg et al. (2000) argued that subduction of Okhotsk lithosphere initiated at the north-eastern Asian margin (East Sikhote-Alin arc) in the late Cretaceous, which we take as the age of the base of the Sakhalin slab, and ending in the late-Cretaceous-Eocene due to accretion of the Okhotsk block. This resulted in a jump of the subduction zone to the east (Kamchatka arc), estimated to have occurred at 65-55 Ma (Gorbatov et al. (2000)), which we have taken as estimate for the end of subduction of the Sakhalin slab.

- $\quad$ Derived midpoint (lon, lat, depth): 14953934

- $\quad$ Age slab (max-min): $92+/-8$ to $68+/-16 \mathrm{Ma}$

- Category: II, Region; Cathaysian 


\section{So - Socorro}

a)

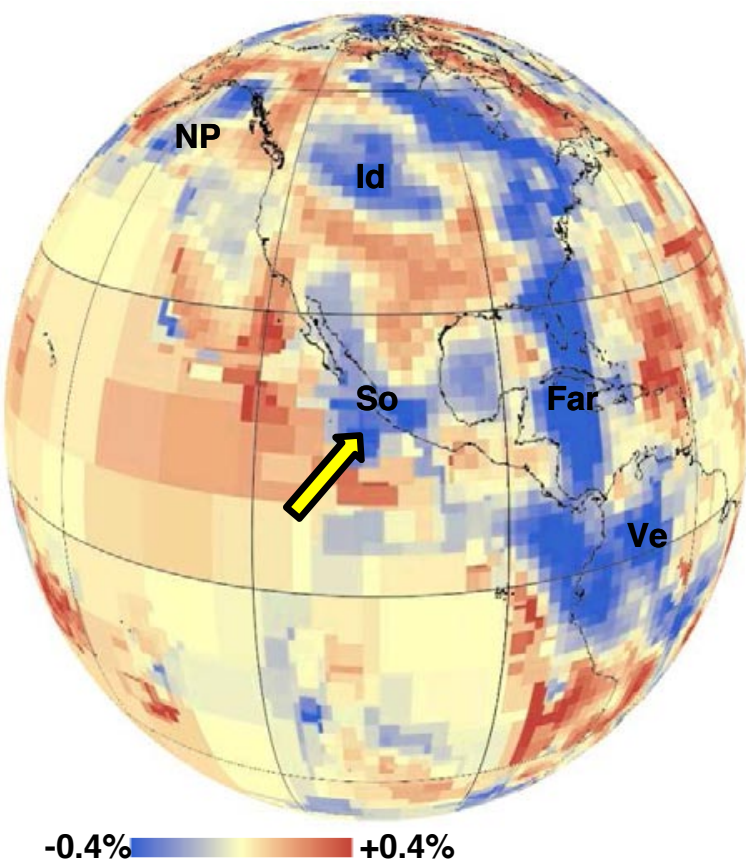

b)

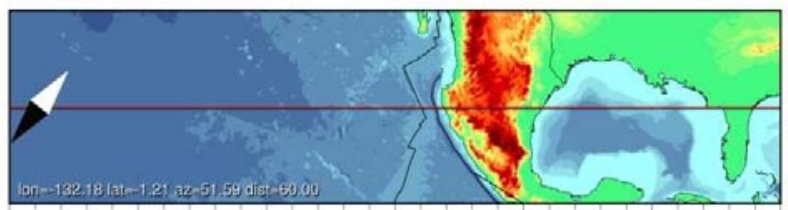

$30 \quad 40$

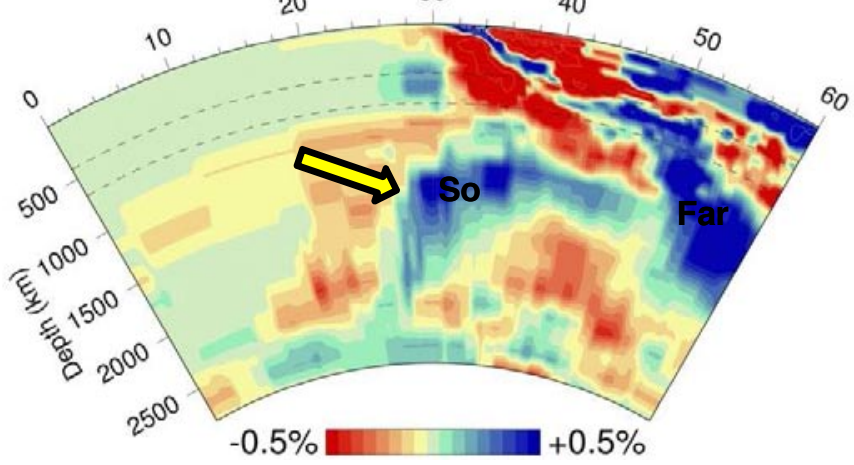

Supplementary Figure 25 Cross-sections of the tomographic model a) horizontal at $1325 \mathrm{~km}$ projected on Earth's surface b) vertical. The slab is indicated by arrows

The Socorro slab is located below Central America within the mid-mantle. It has not been described before. The Id-slab and So-slab are nearly similar in depth, dip, and have a more westerly location than the $1^{\text {st }}$ order Farallon slab. Similar to the Id-slab we have interpreted an intra-oceanic Jurassic-Cretaceous origin for this slab. The Wrangellia superterrane has both a northern and southern scenario indicated by paleomagnetic data (Nokleberg et al. (2000)). This indicates that the superterrane has had a dual origin, a northern and southern part. After final accretion near the Baja British Columbia, these terranes have been placed close to each other and could have been mistaken for one superterrane with a single history. Similarly as the interpretation of the $2^{\text {nd }}$-order Id-slab, we associate eastward subduction of Panthalassa/Farallon lithosphere at the southern part of the Wrangellia terrane to have caused the So-slab, starting in the early to middle Jurassic. Accretion of the terrane with Laurentia started in the late Jurassic (Trop et al., (2005)) and ended in the early to late Cretaceous (Nokleberg et al. (2000)).

- $\quad$ Derived midpoint (lon, lat, depth): - 108171485

- $\quad$ Age slab (max-min): $186+/-23$ to $92+/-8 \mathrm{Ma}$

- $\quad$ Category: II, Region; Laurentian 


\section{TA - Trans-Americas}

a)

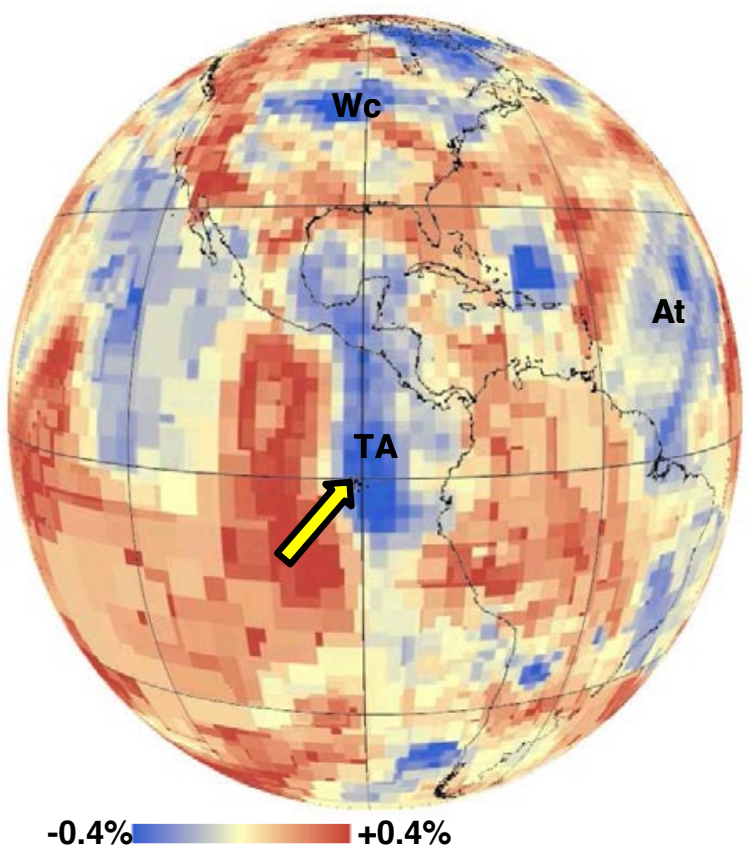

b)

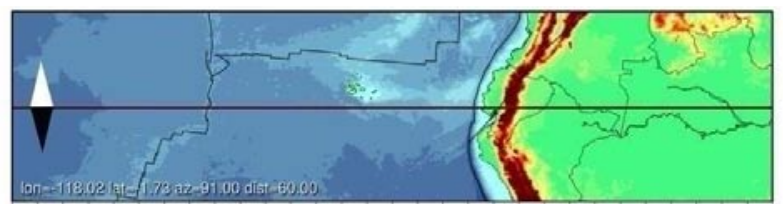

30

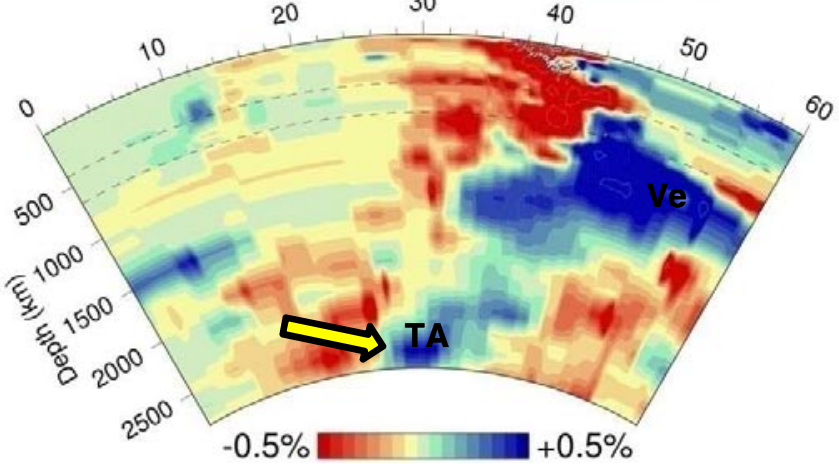

Supplementary Figure 26 Cross-sections of the tomographic model a) horizontal at $2650 \mathrm{~km}$ projected on Earth's surface $b$ ) vertical. The slab is indicated by arrows

- $\quad$ The Trans-Americas slab is located below the Cocos plate and Central America from the $\mathrm{CMB}$ up to the deep mantle. It has been detected in previous seismological (Thomas et al. (2004), Hutko et al. (2006), Kito et al. (2007)) and tomographic studies (van der Hilst et al. (2007)) and interpreted as the result of folding and westward spreading of the Farallon slab (Hutko2006). The base of the $1^{\text {st }}$ order Farallon slab to the east and the base of the $2^{\text {nd }}$ order Id-slab to the north were used to infer that the Trans-Americas slab represents subducted lithosphere of at least middle Mesozoic age. The tomographic model (Amaru (2007)) indicates the slab dips westward and its top is close to the Farallon\&Venezuela slabs. This suggests eastward trench motion at the time of subduction. Our preferred interpretation is that the slab has an early Mesozoic intra-oceanic origin with the arc accreting at the Laurentian margin during the middle Mesozoic. The Stikinia-Quesnellia arc fits this scenario which we have interpreted to be the surficial remnant of the slabs' subduction. This arc initiated in the middle-late Triassic and accreted to Laurentia in the early-middle Jurassic (Nokleberg et al. (2000), Johnston and Borel (2007)). An alternative scenario for this slab would be subduction of Farallon/Panthalassa lithosphere in the Permian to Triassic (Ziegler (1989), Ward (1995), Cawood and Buchan (2007)) associated with the Sonoma orogeny at the western margin of Laurentia.

- $\quad$ Derived midpoint (lon, lat, depth): -88 -2 2624

- $\quad$ Age slab (max-min): $219+/-11$ to $178+/-15 \mathrm{Ma}$

- $\quad$ Category: II, Region; Laurentian 


\section{Ve - Venezuela}

a)

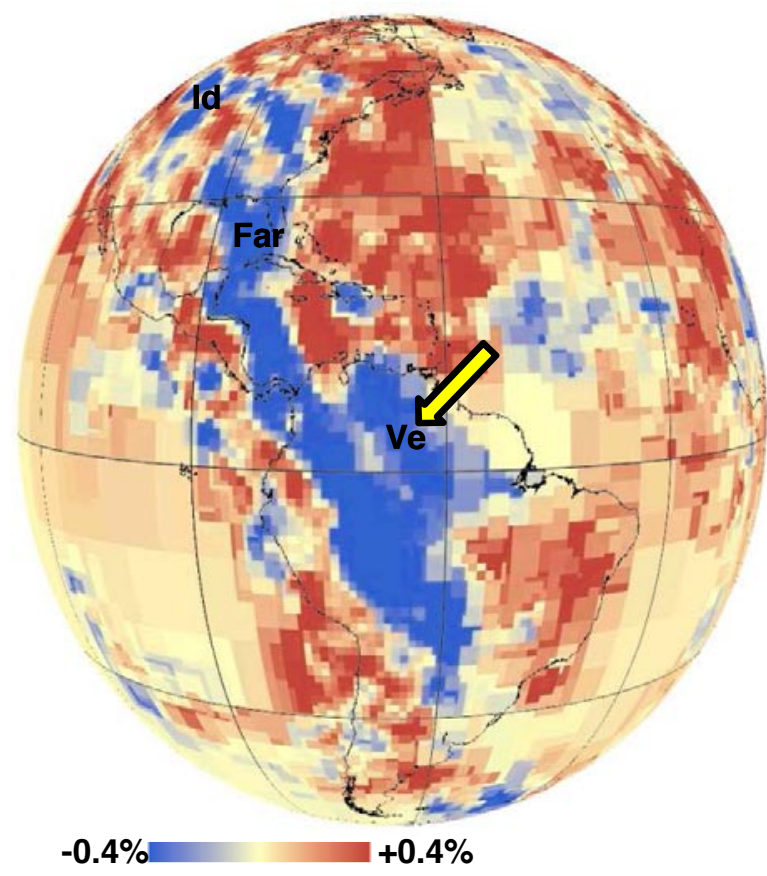

b)
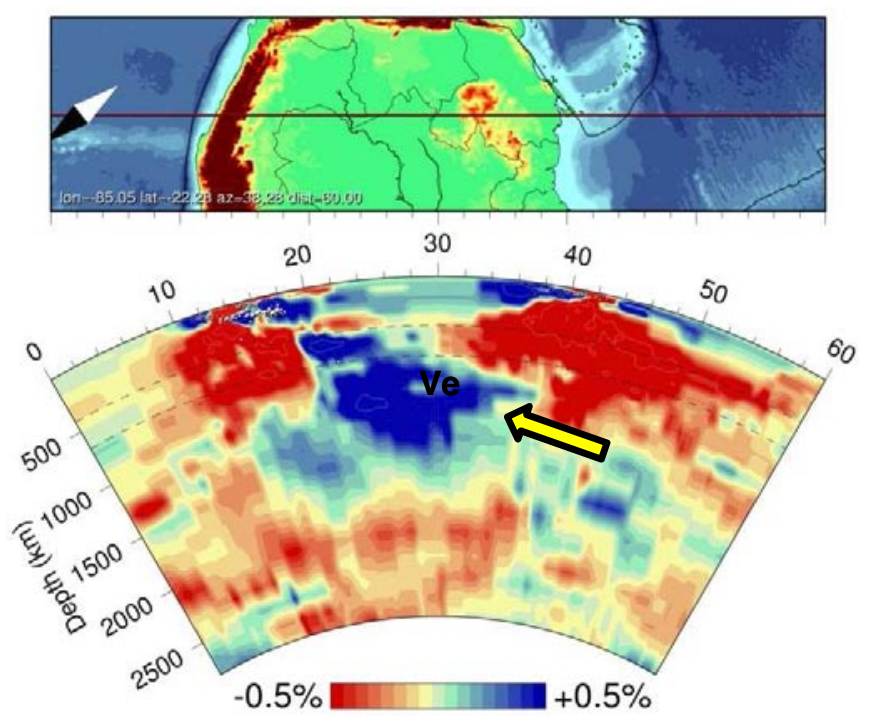

Supplementary Figure 27 Cross-sections of the tomographic model a) horizontal at $920 \mathrm{~km}$ projected on Earth's surface $b$ ) vertical. The slab is indicated by arrows

The Venezuela slab is located below northern South America from the mid-mantle up to the upper part of the lower mantle. It has not previously been described in tomographic or seismological studies. The $1^{\text {st }}$ order Caribbean slab higher in the mantle to the northeast and the $1^{\text {st }}$ order Farallon slab to the northwest were used to infer that the Venezuela slab likely corresponds to an older subduction event, which in this region most likely corresponds to south-westward subducted Atlantic/protoCaribbean lithosphere of at least $110 \mathrm{Ma}$ (García-Casco et al. (2008a\&b), Krebs et al. (2008)), and likely older than $118 \mathrm{Ma}$ (García-Casco et al. (2002), Lázaro et al. (2009)) until latest Cretaceous-Paleocene (Harlow et al. (2004), García-Casco et al. (2008), Krebs et al. (2008), Brueckner et al. (2009)), in line with earlier inferences of Burke (1988) and Ross and Scotese (1988).

- $\quad$ Derived midpoint (lon, lat, depth): -6721086

- $\quad$ Age slab (max-min): $114+/-4$ to $66+/-7 \mathrm{Ma}$

- $\quad$ Category: II, Region; Laurentian 


\section{Wc - Wichita}

a)

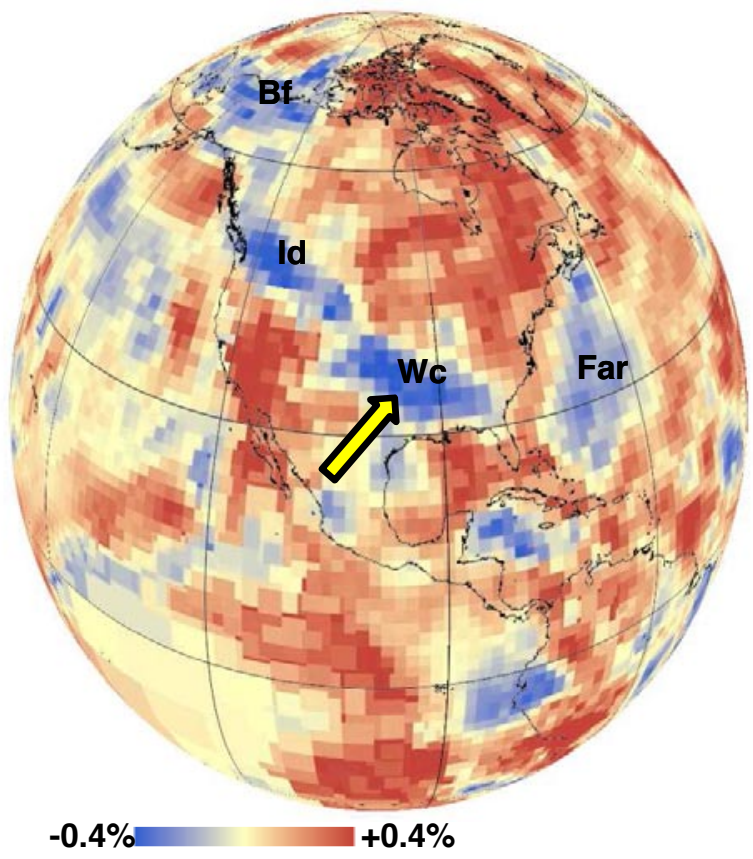

b)

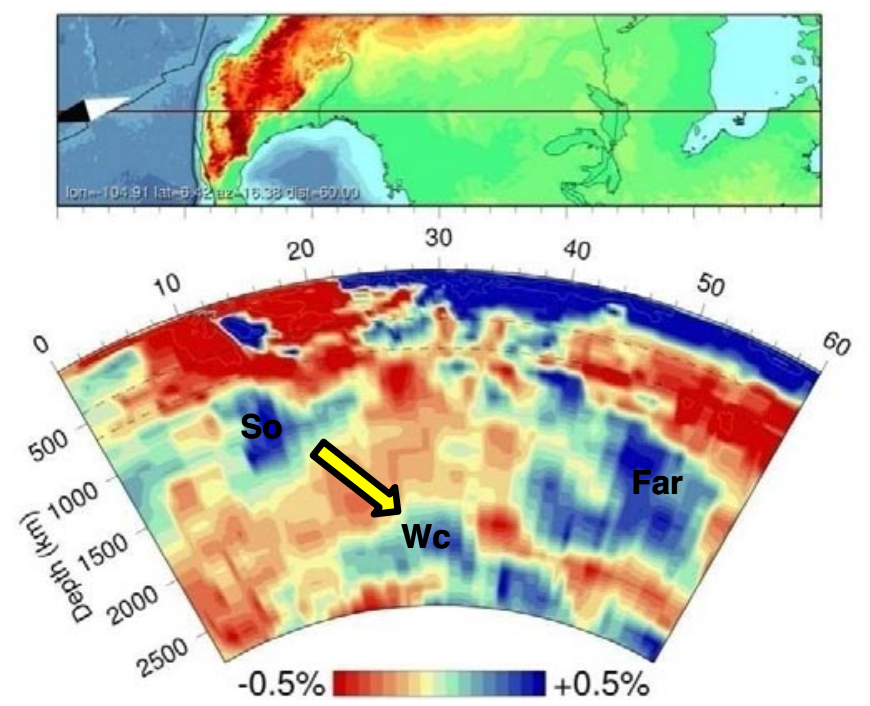

Supplementary Figure 28 Cross-sections of the tomographic model a) horizontal at 2300 km projected on Earth's surface b) vertical. The slab is indicated by arrows

The Wichita slab is located below central Laurentia from the CMB up to deep mantle. It has not been previously described. The presence of the $1^{\text {st }}$ order Farallon slab to the east renders it likely that the Wichita slab represents subducted lithosphere of early Mesozoic age. Since the Farallon slab is associated with subduction at the Laurentian continental margin, the Wichita slab most likely represents the timeequivalent intra-oceanic subduction zone consuming Panthalassa lithosphere, to create part of the intra-oceanic Stikinia-Quesnellia arc (with the other part associated with the TA slab), starting in the middle-late Triassic and ending in the early-middle Jurassic by accretion to Laurentia (Nokleberg et al. (2000), Johnston and Borel (2007)).

- $\quad$ Derived midpoint (lon, lat, depth): -95 352366

- Age slab (max-min): $219+/-11$ to $178+/-15 \mathrm{Ma}$

- Category: II, Region; Laurentian 
a)

\section{$500 \mathrm{~km}$ - $40 \mathrm{Ma}$}

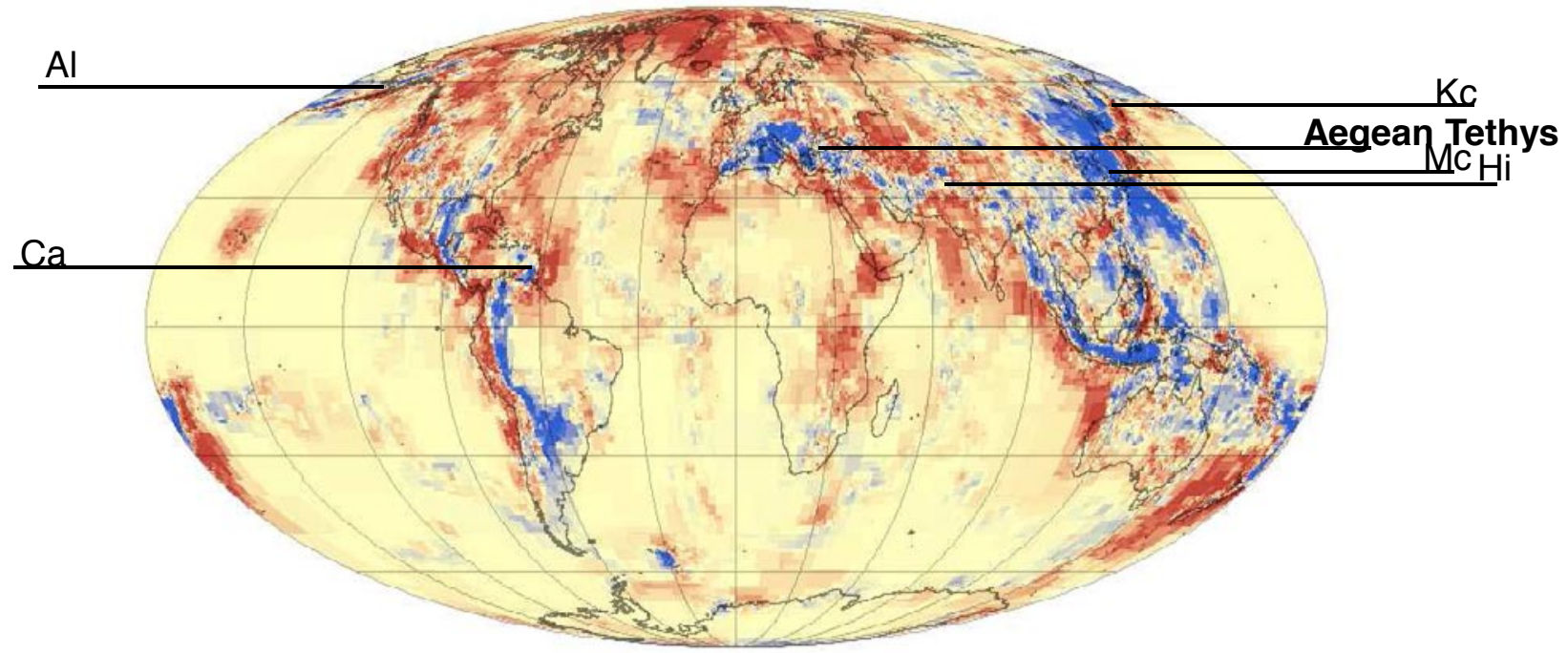

Legend

P-wave velocity anomaly

$-0.8 \%+0.8 \%$

b)

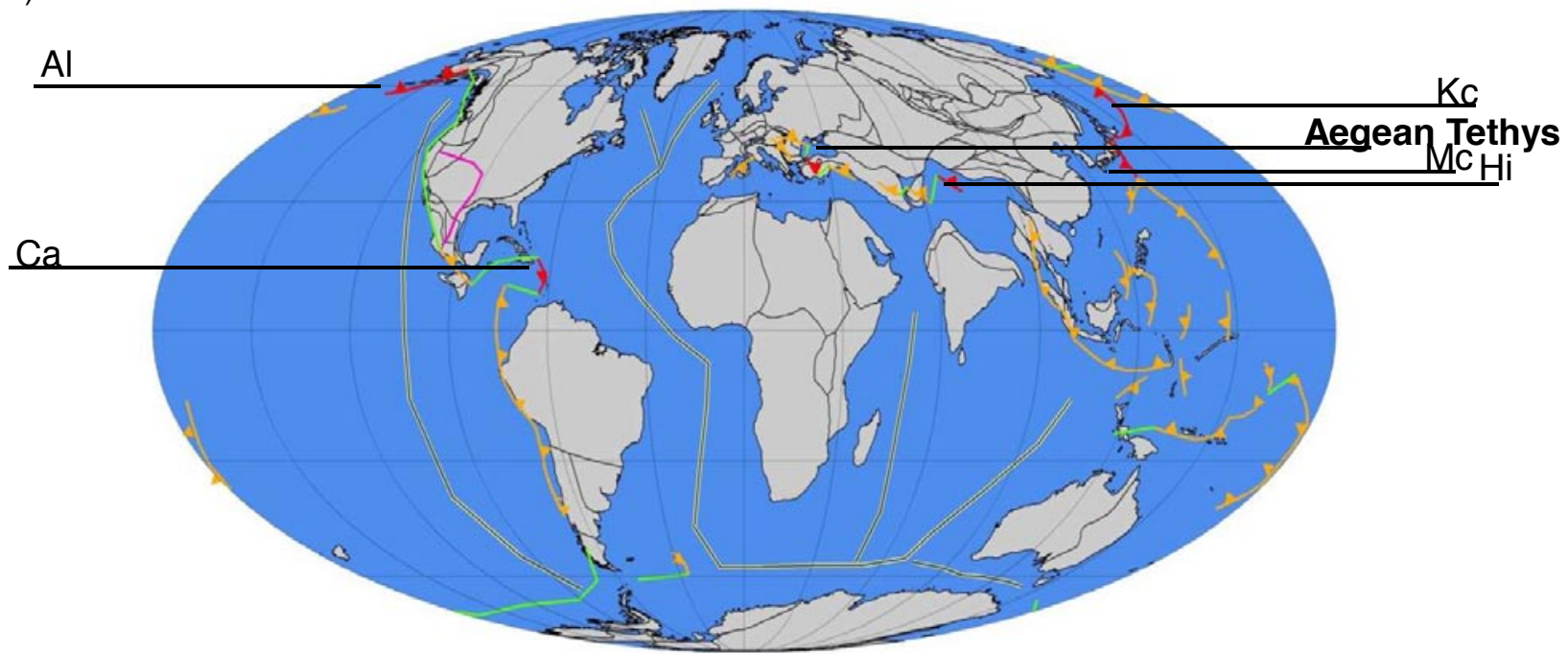

- Subduction 1st-3rd category Spreading Ridge

_. Other subduction Zones__ Transfer zones

_ Flat Slab Subduction

Supplementary Figure 29 a) Tomographic slice at $500 \mathrm{~km}$ depth of Amaru (2007) projected to the earth's surface, b) modified reconstruction of Torsvik et al. (2008) at $40 \mathrm{Ma}$ with the interpreted subduction zones and other tectonic features. Within the upper mantle many slabs are recognised to be continuations of presently active subducting plates (Aegean Tethys, $\mathrm{Ca}, \mathrm{Kc}, \mathrm{Mc}$ ). Also there are detached slabs visible of at least Mid-Cenozoic age (Hi). The age range of the slabs at this depth varies significantly, due to differences in sinking rates and slab dips, but is less then $70 \mathrm{Ma}$. This is in agreement with the Farallon anchor point deeper in the mantle that suggest that slabs at this depth are likely younger then 70-80 Ma. A global 2 degree westward shift was applied to the 40 Ma plate tectonic reconstruction (Torsvik et al. (2008)) to obtain a best-fit for this depth. Our interpretation of this depth slice is restricted to a global overview of Recent-Cenozoic subduction before entering the lower mantle. Within the upper mantle more focussed interpretations can be obtained from regional studies all around the globe. 
a)

\section{$710 \mathrm{~km}-60 \mathrm{Ma}$}

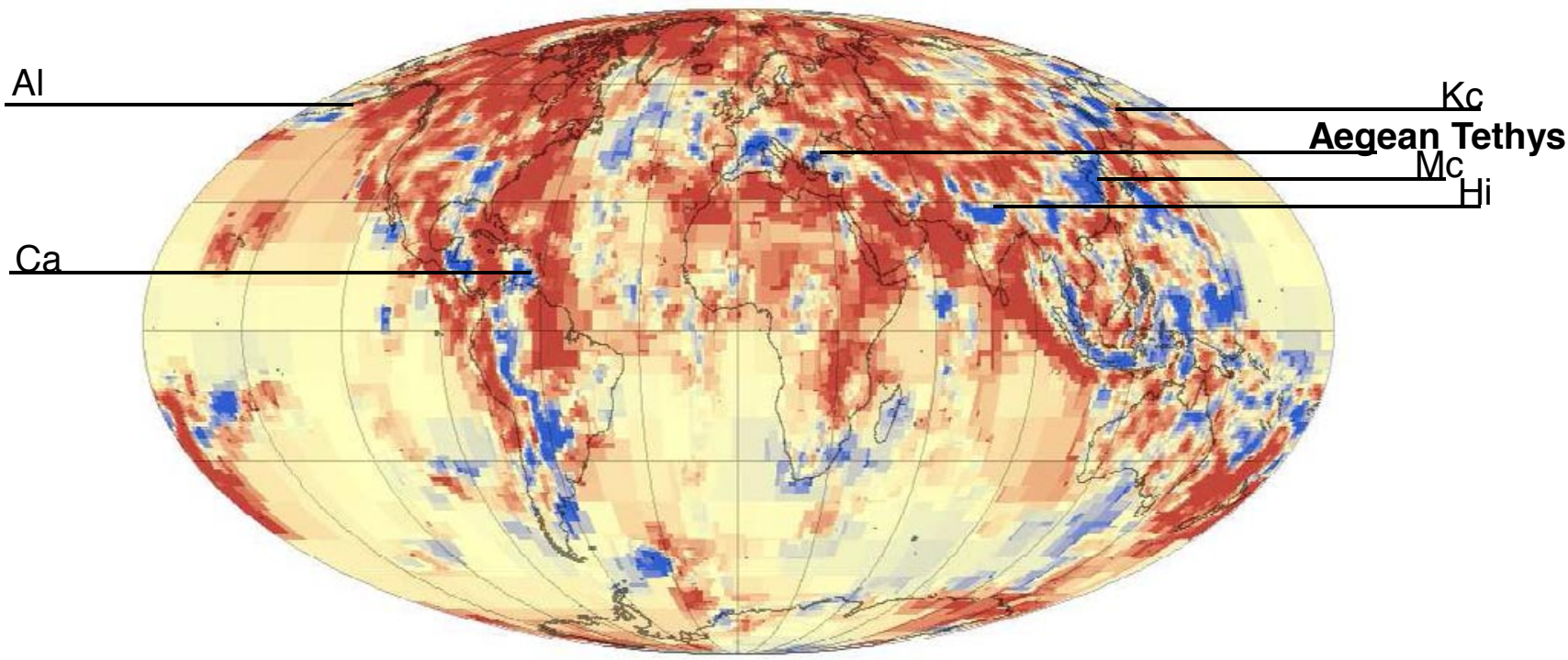

Legend

P-wave velocity anomaly

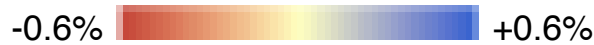

b)

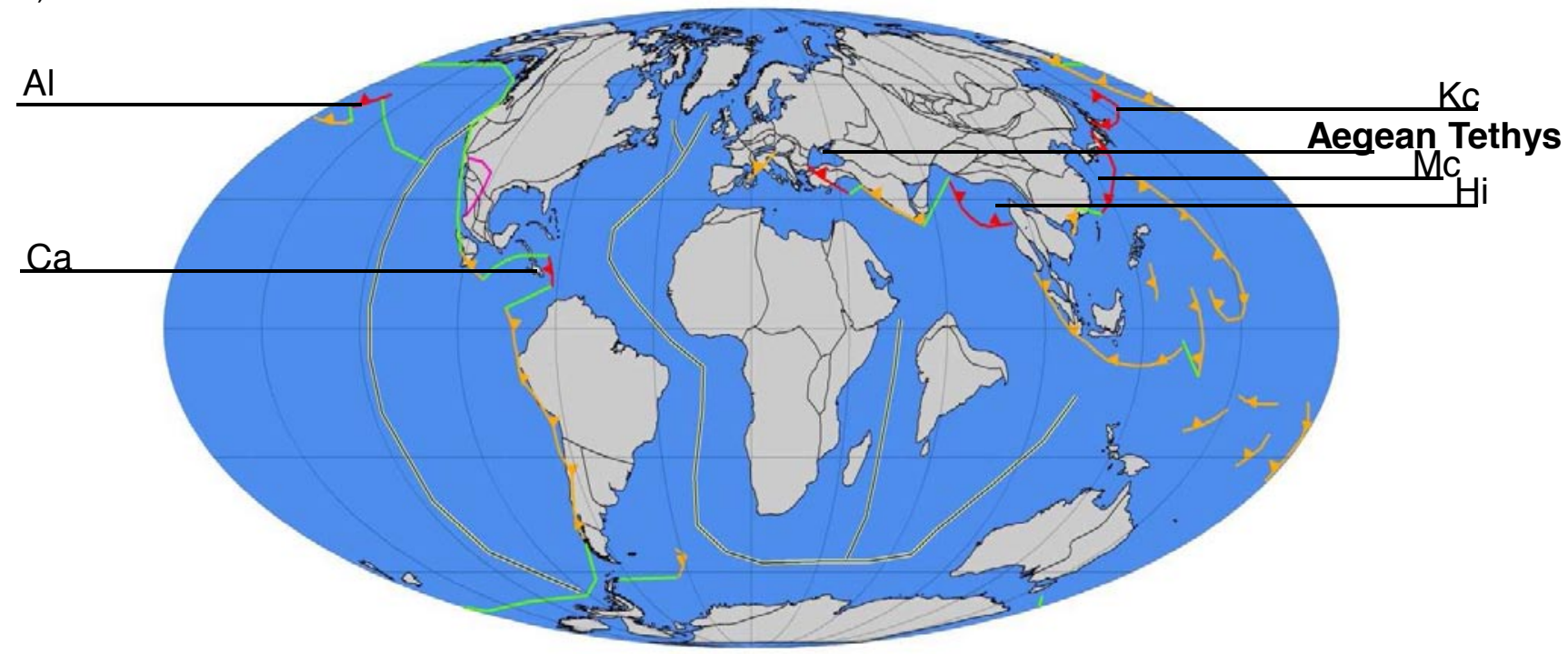

- Subduction 1st-3rd category Spreading Ridge

A. Other subduction Zones__ _Transfer zones

_ Flat Slab Subduction

Supplementary Figure 30 a) Tomographic slice at $710 \mathrm{~km}$ depth of Amaru (2007) projected to the earth's surface, b) modified reconstruction of Torsvik et al. (2008) at $60 \mathrm{Ma}$ with the interpreted subduction zones and other tectonic features. At the top of the lower mantle, many slabs are recognised to be continuations of presently active subducting plates (Aegean Tethys, $\mathrm{Ca}, \mathrm{Kc}, \mathrm{Mc}$ ). Also there are detached slabs visible of at least Mid-Cenozoic in age (Hi). The age interpretaton of the slabs at this depth is 40-70 Ma. This is in agreement with the Farallon anchor point deeper in the mantle that suggest that slabs at this depth are likely younger then 70-80 Ma. A global 6 degree westward shift was applied to the 60 Ma plate tectonic reconstruction (Torsvik et al. (2008)) to obtain a best-fit for this depth. 
a)

\section{$920 \mathrm{~km}-80 \mathrm{Ma}$}

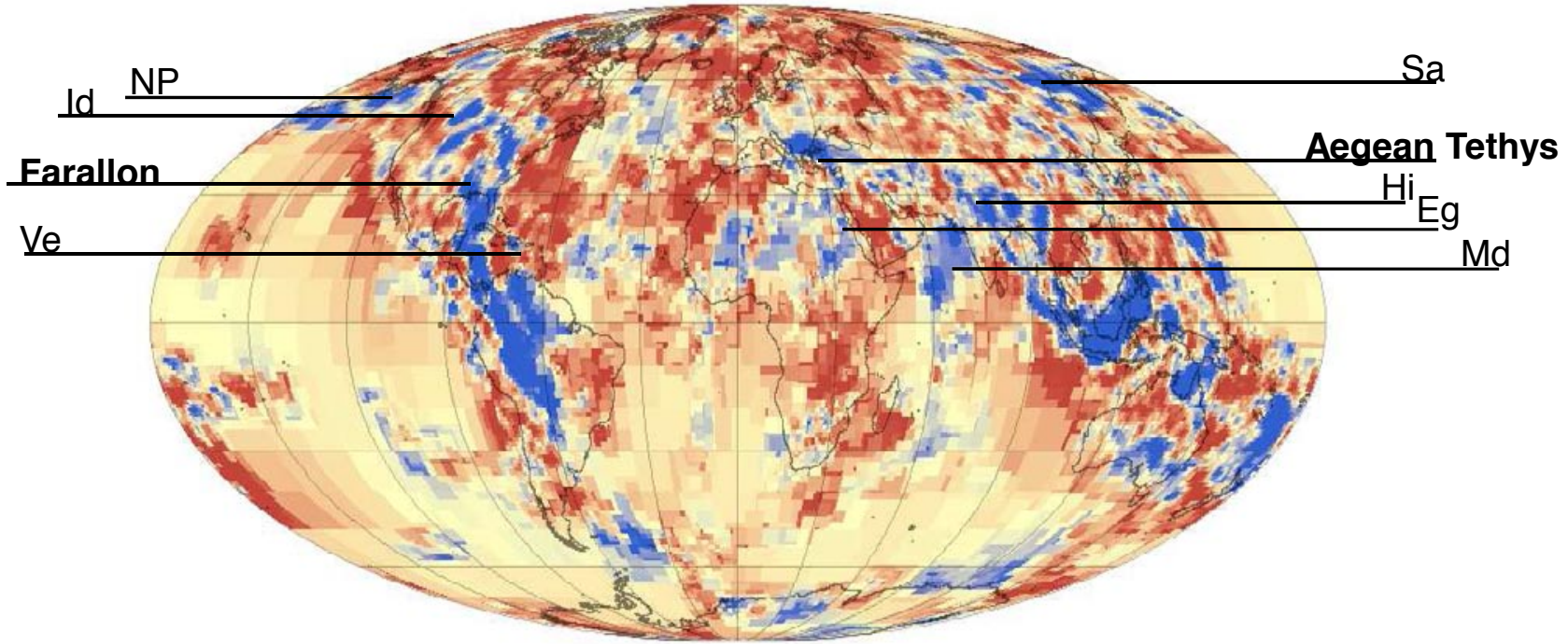

Legend

P-wave velocity anomaly

$-0.4 \%+0.4 \%$

b)

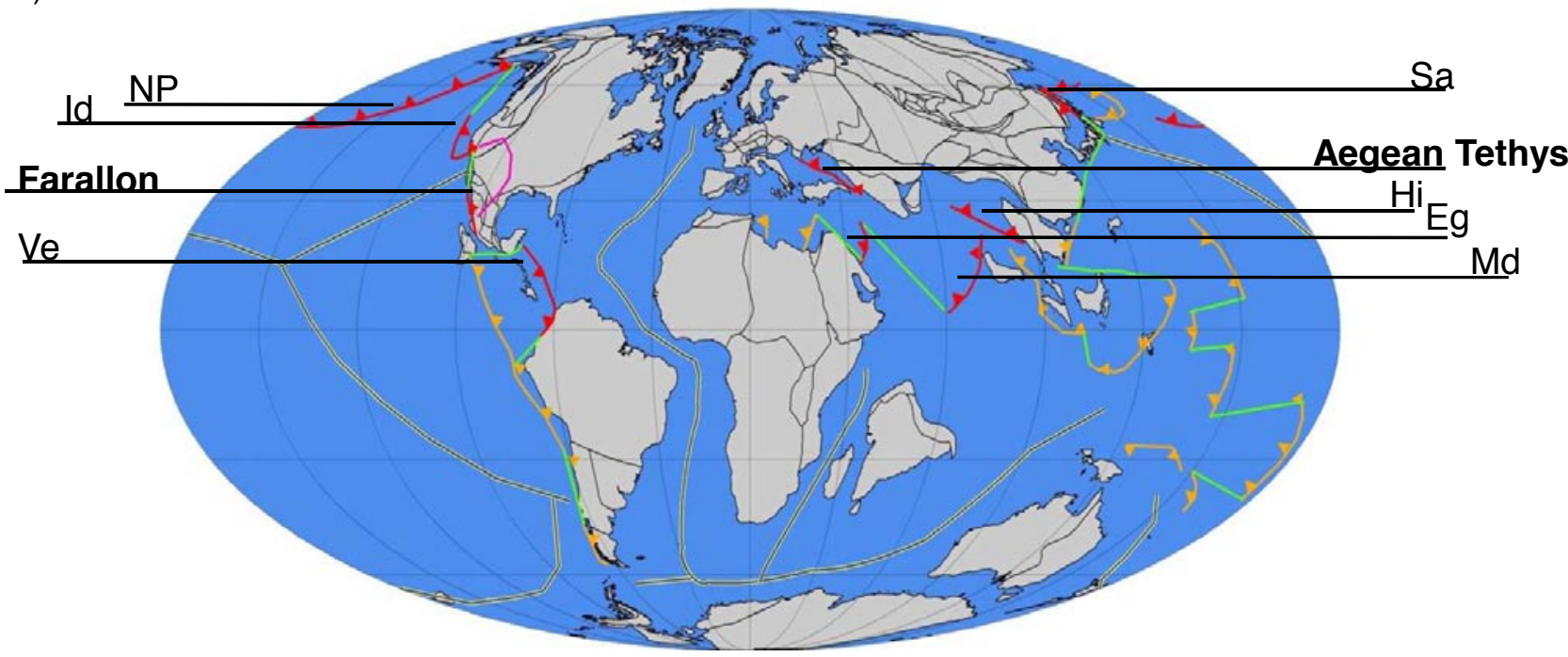

- Subduction 1st-3rd category Spreading Ridge

A. Other subduction Zones__ _Transfer zones

Flat Slab Subduction

Supplementary Figure 31 a) Tomographic slice at $920 \mathrm{~km}$ depth of Amaru (2007) projected to the earth's surface, b) modified reconstruction of Torsvik et al. (2008) at $80 \mathrm{Ma}$ with the interpreted subduction zones and other tectonic features. The top of the Farallon slab is found at this depth. This slab was defined by Grand et al. (1997) but the top was interpreted at the present subduction zone. However above $920 \mathrm{~km}$ depth the continuous Farallon slab becomes discontinuous and disappears. What remains are dispersed fragments due to the Laramide orogeny, as described by van der Lee and Nolet (1997). Therefore we have taken the start of the Laramide orogeny 70-80 Ma (Dickinson and Snyder (1978)) as the top of the redefined Farallon slab. Interpretations of other slabs yields 60-100 Ma.

A global 8 degree westward shift was applied to the 80 Ma plate tectonic reconstruction (Torsvik et al. (2008)) to obtain a best-fit for this depth. 
a)

$1175 \mathrm{~km}-100 \mathrm{Ma}$

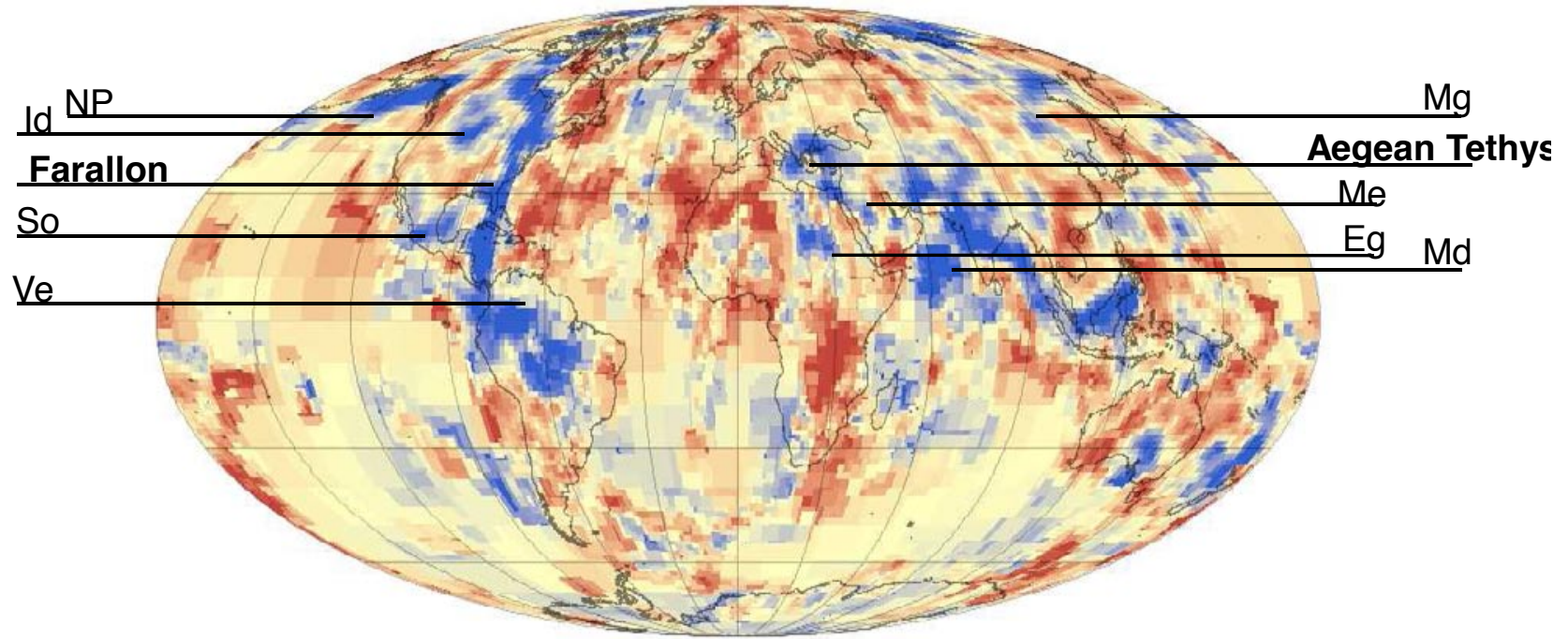

Legend

P-wave velocity anomaly

$-0.4 \%+0.4 \%$

b)

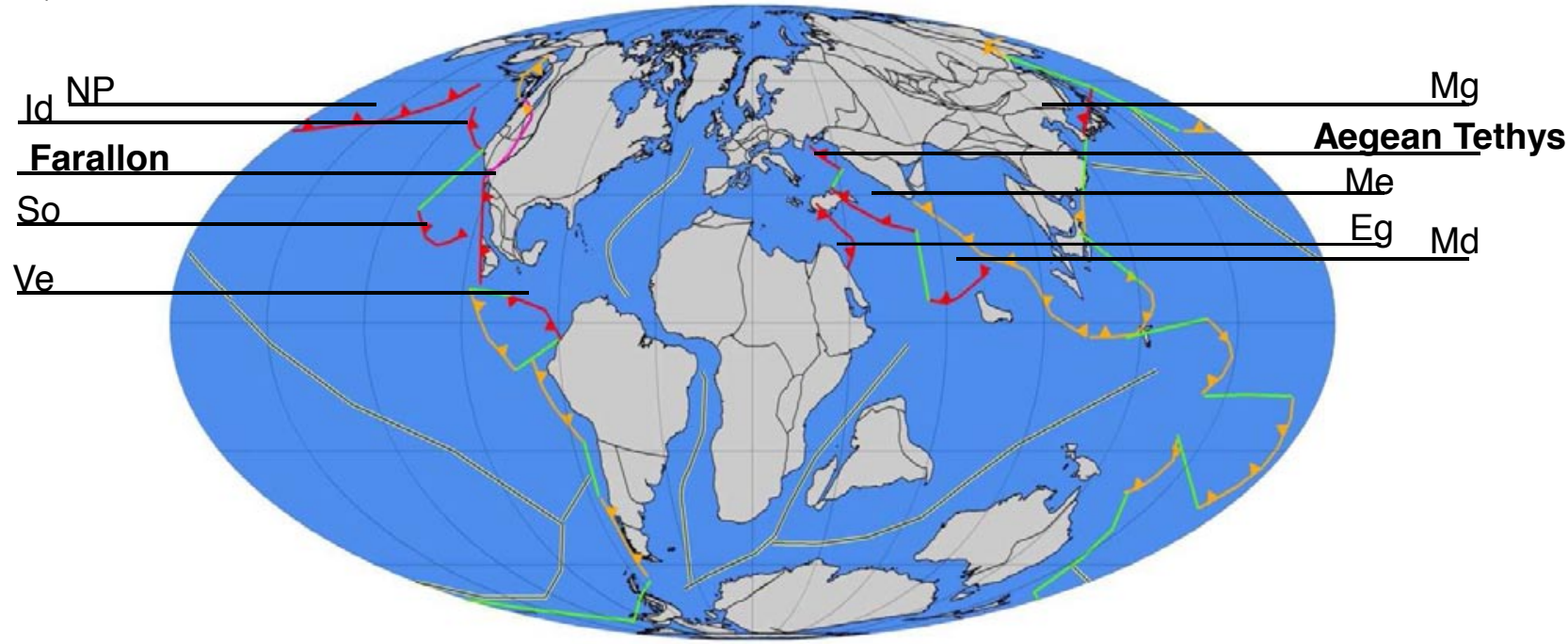

^ Subduction 1st-3rd category Spreading Ridge

A. Other subduction Zones_-Transfer zones

_ Flat Slab Subduction

Supplementary Figure 32 a) Tomographic slice at $1175 \mathrm{~km}$ depth of Amaru (2007) projected to the earth's surface, b) modified reconstruction of Torsvik et al. (2008) at $100 \mathrm{Ma}$ with the interpreted subduction zones and other tectonic features. Based on the Farallon and Aegean Tethys anchor point above and below respectively, an age of $\sim 100 \mathrm{Ma}$ is expected for this depth. Interpretations of other slabs yields 90-120 Ma. A global 14 degree westward shift was applied to the 100 Ma plate tectonic reconstruction (Torsvik et al. (2008)) to obtain a best-fit for this depth. 
a)

\section{$1325 \mathrm{~km}-120 \mathrm{Ma}$}

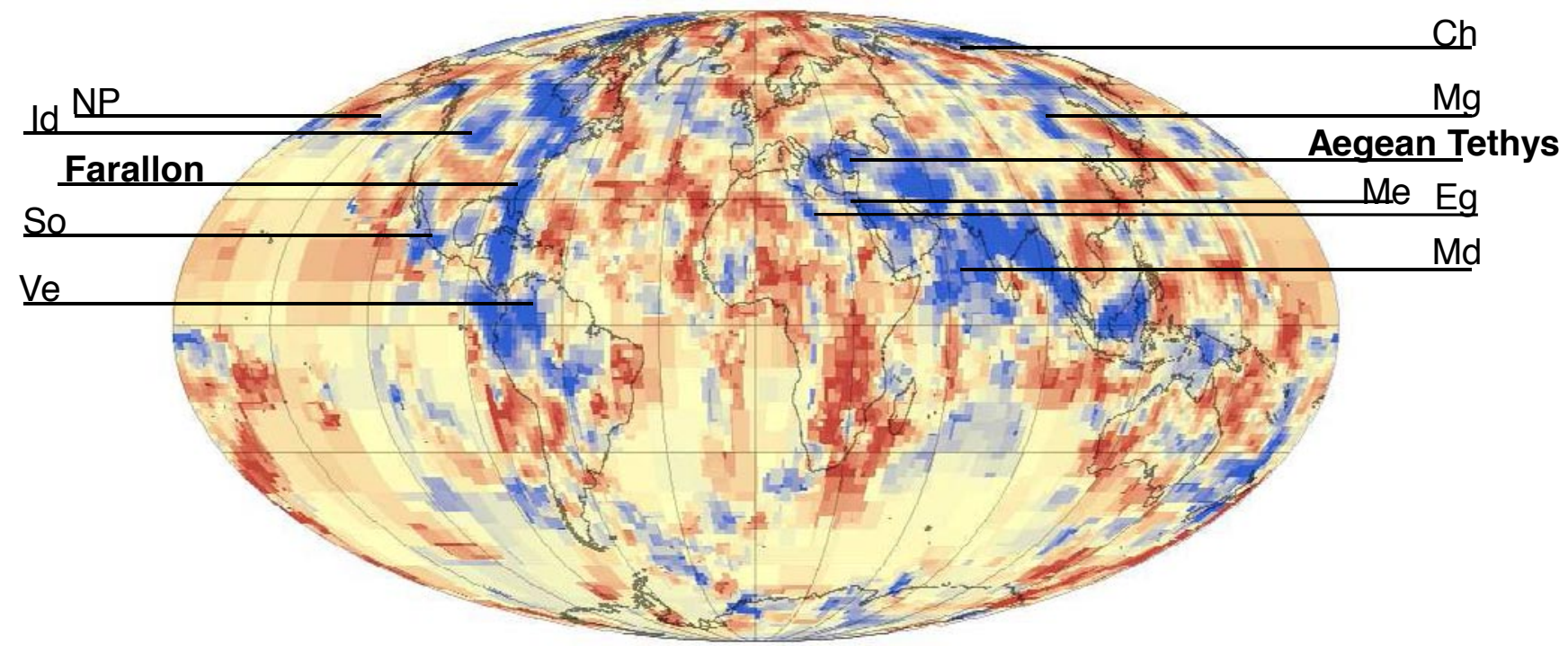

Legend

P-wave velocity anomaly

$-0.4 \%+0.4 \%$

b)

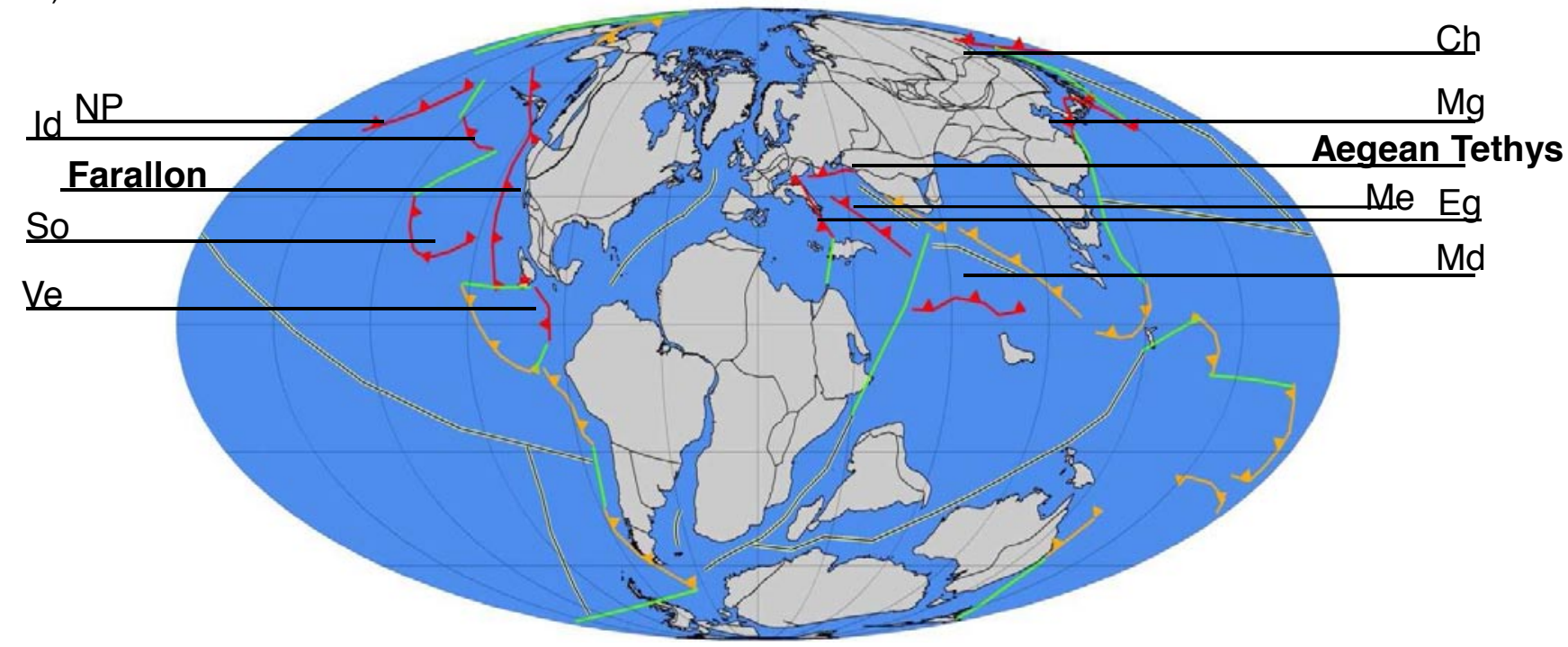

^ Subduction 1st-3rd category Spreading Ridge

_. Other subduction Zones__ _Transfer zones

_ Flat Slab Subduction

Supplementary Figure 33 a) Tomographic slice at $1325 \mathrm{~km}$ depth of Amaru (2007) projected to the earth's surface, b) modified reconstruction of Torsvik et al. (2008) at $120 \mathrm{Ma}$ with the interpreted subduction zones and other tectonic features. Based on the Farallon and Aegean Tethys anchor point above and below respectively, an age of $\sim 110 \mathrm{Ma}$ is expected for this depth. Interpretations of other slabs yields 95-130 Ma. A global 17 degree westward shift was applied to the 120 Ma plate tectonic reconstruction (Torsvik et al. (2008)) to obtain a best-fit for this depth. 
a)

\section{$1700 \mathrm{~km}-140 \mathrm{Ma}$}

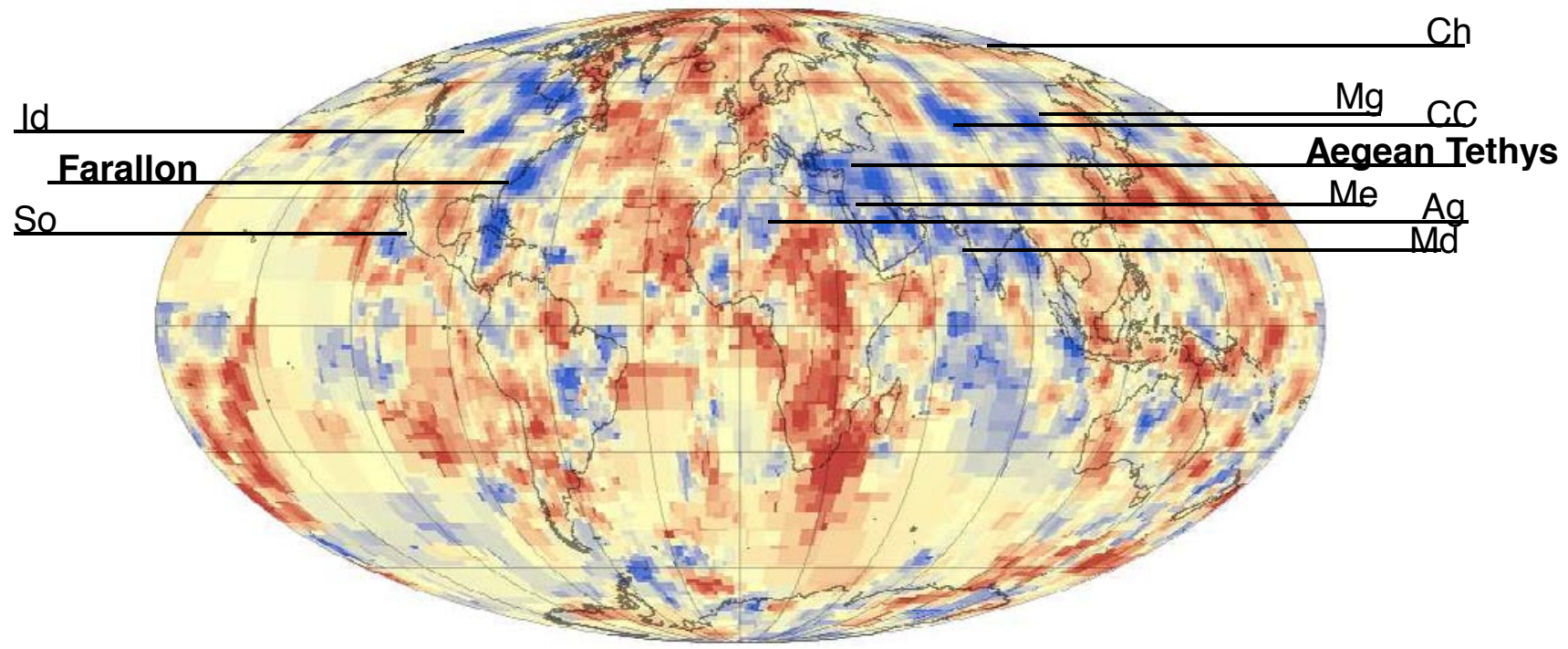

Legend

P-wave velocity anomaly

$-0.4 \%+0.4 \%$

b)

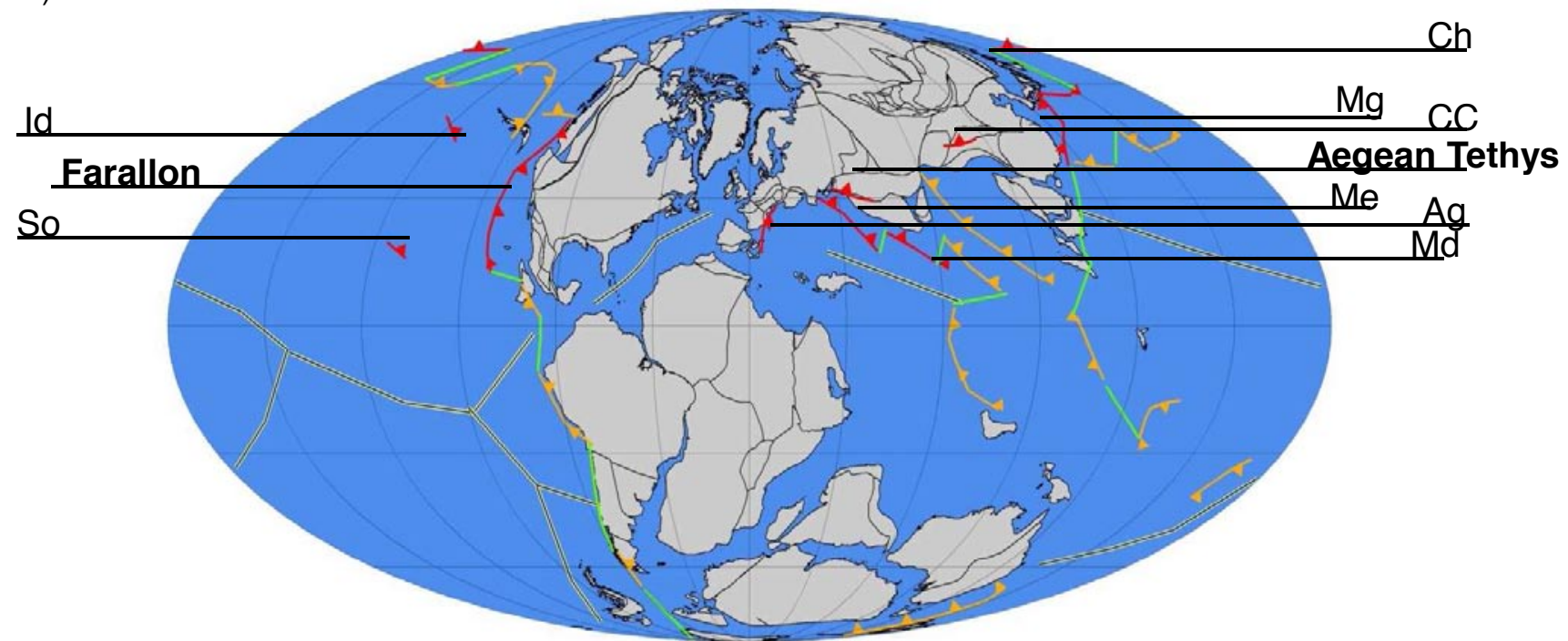

^ Subduction 1st-3rd category Spreading Ridge

A. Other subduction Zones_-Transfer zones

_ Flat Slab Subduction

Supplementary Figure 34 a) Tomographic slice at $1700 \mathrm{~km}$ depth of Amaru (2007) projected to the earth's surface, b) modified reconstruction of Torsvik et al. (2008) at 140 Ma with the interpreted subduction zones and other tectonic features. Based on the Farallon and Aegean Tethys anchor point above and below respectively, an age of $\sim 135 \mathrm{Ma}$ is expected for this depth. Interpretations of other slabs yields 130-165 Ma. A global 18 degree westward shift was applied to the 140 Ma plate tectonic reconstruction (Torsvik et al. (2008)) to obtain a best-fit for this depth. 
a)

\title{
$1900 \mathrm{~km}-160 \mathrm{Ma}$
}
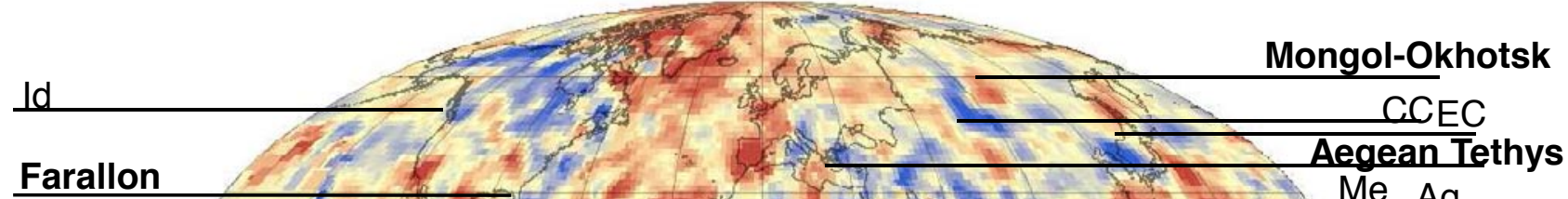
So

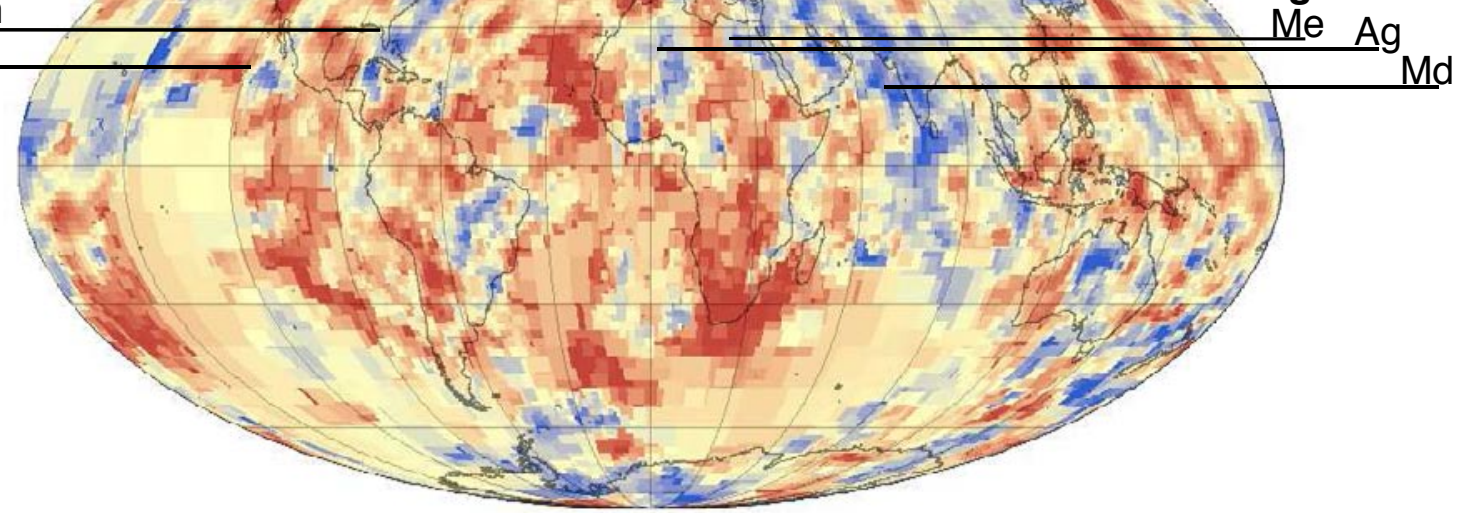

\begin{abstract}
Legend
P-wave velocity anomaly

$-0.4 \%+0.4 \%$
\end{abstract}

b)

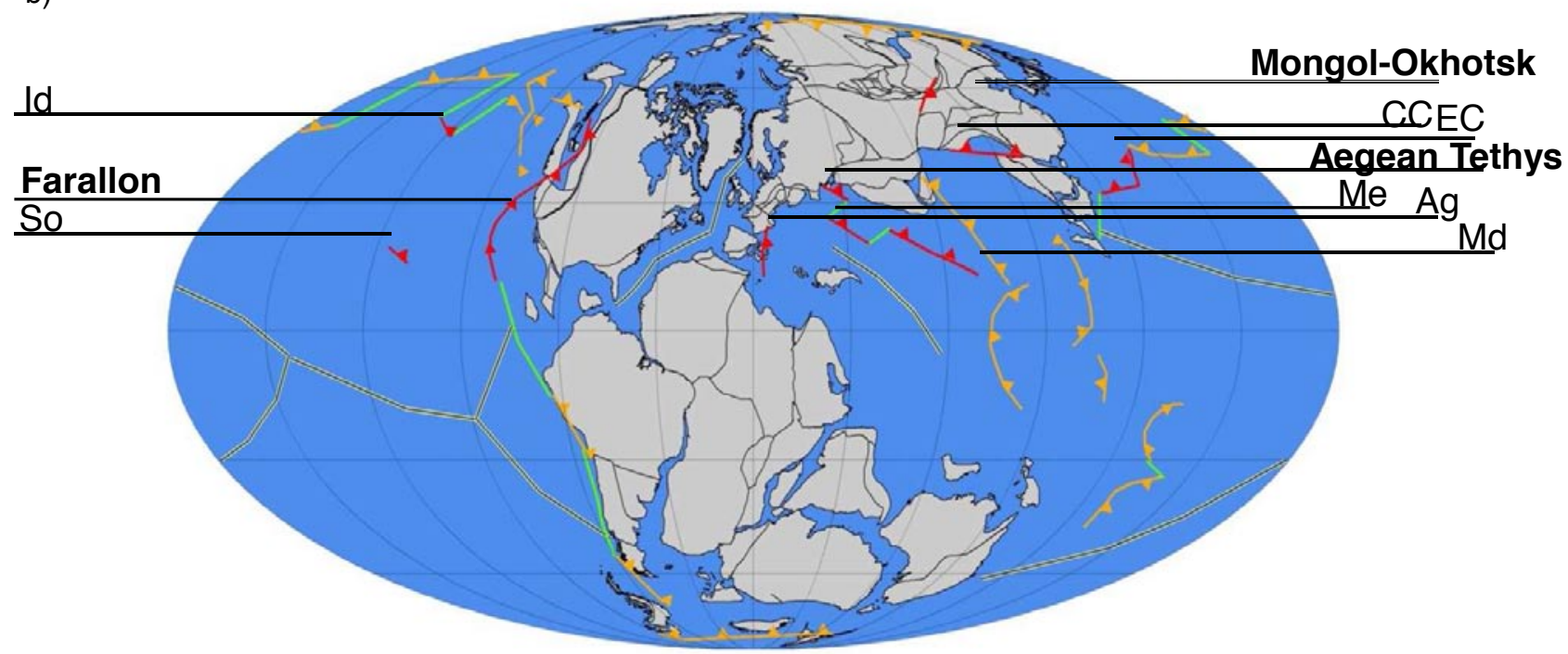

- Subduction 1st-3rd category Spreading Ridge

A. Other subduction Zones_-Transfer zones

_ Flat Slab Subduction

Supplementary Figure 35 a) Tomographic slice at $1900 \mathrm{~km}$ depth of Amaru (2007) projected to the earth's surface, b) modified reconstruction of Torsvik et al. (2008) at $160 \mathrm{Ma}$ with the interpreted subduction zones and other tectonic features. The base of Aegean Tethys slab found at this depth was identified by van Hinsbergen et al. (2005) of approximately the age of the Jurassic-Cretaceous boundary. According to Stampfli and Borel (2004) subduction initiated in this region between 180 and $155 \mathrm{Ma}$. Based on the Farallon and Mongol-Okhotsk anchor points, above and below respectively an age of $\sim 150 \mathrm{Ma}$ is expected for this depth. Interpretations of other slabs yields 145-180 Ma. A global 18 degree westward shift was applied to the 160 Ma plate tectonic reconstruction (Torsvik et al. (2008)) to obtain a best-fit for this depth. 
a)

\section{$2100 \mathrm{~km}-180 \mathrm{Ma}$}

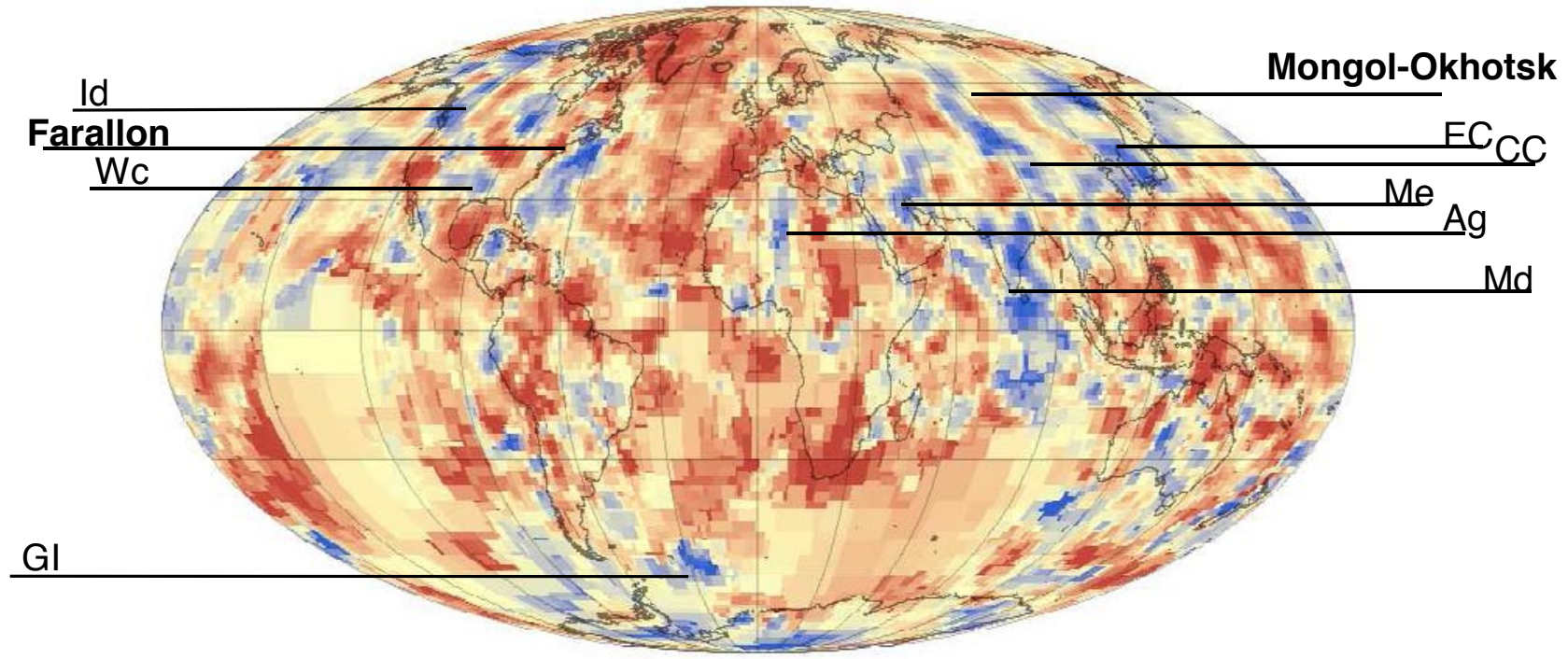

Legend

P-wave velocity anomaly

$-0.4 \%+0.4 \%$

b)

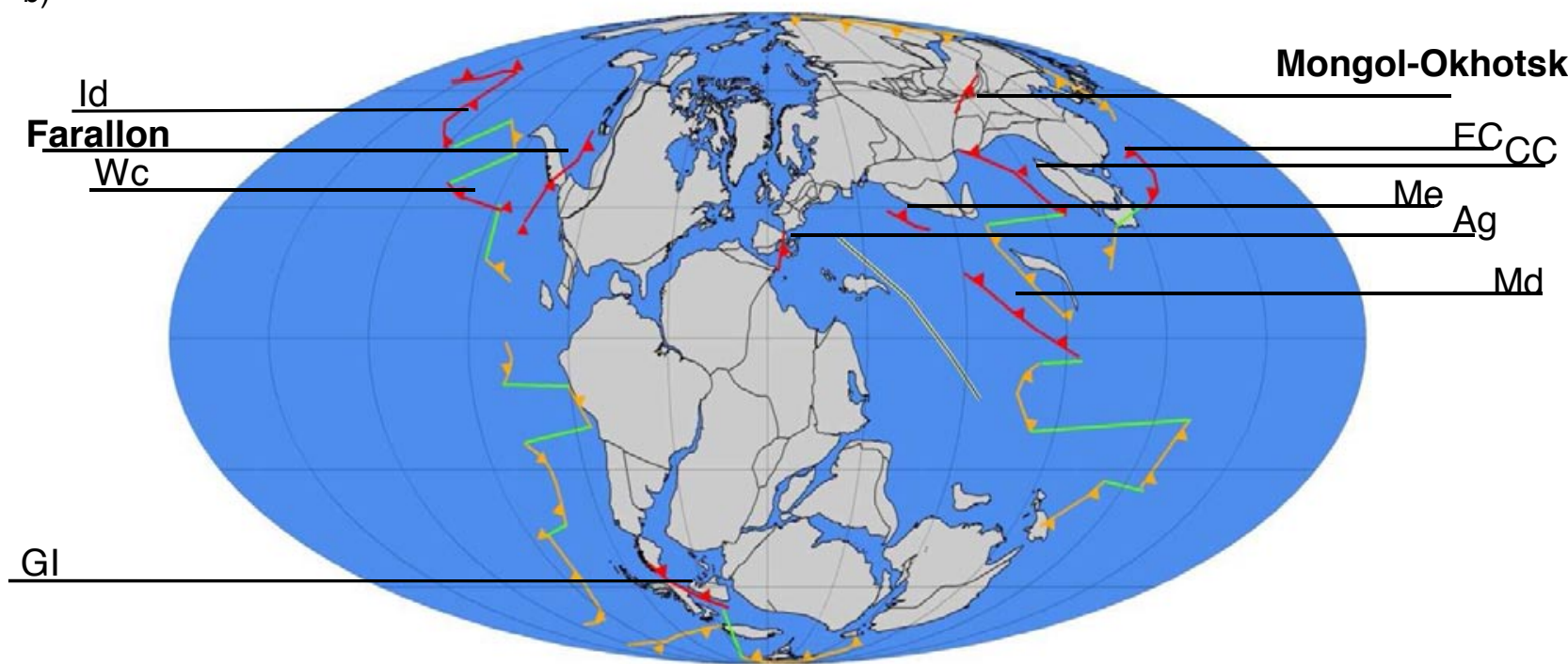

- Subduction 1st-3rd category Spreading Ridge

- Other subduction Zones_-Transfer zones

_ Flat Slab Subduction

Supplementary Figure 36 a) Tomographic slice at $2100 \mathrm{~km}$ depth of Amaru (2007) projected to the earth's surface, b) modified reconstruction of Torsvik et al. (2008) at $180 \mathrm{Ma}$ with the interpreted subduction zones and other tectonic features. Based on the top Farallon and Aegean Tethys anchor point above and the Mongol-Okhotsk and base Farallon anchor points below respectively, an age of $\sim 170 \mathrm{Ma}$ is expected for this depth. Interpretations of other slabs yields 150-210 Ma. A global 17 degree westward shift was applied to the 180 Ma plate tectonic reconstruction (Torsvik et al. (2008)) to obtain a best-fit for this depth. 
a)
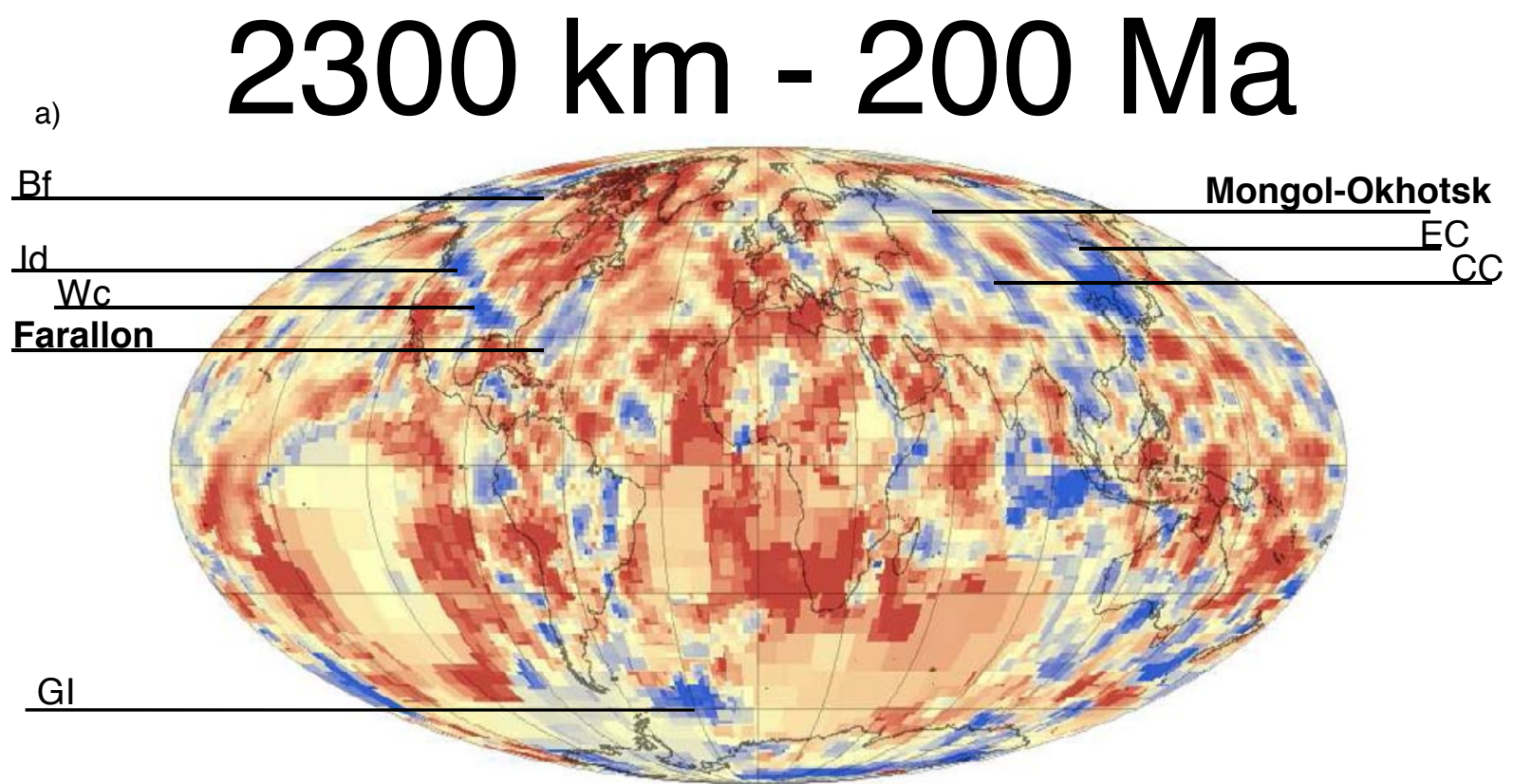

Legend

P-wave velocity anomaly

$-0.4 \%+0.4 \%$

b)

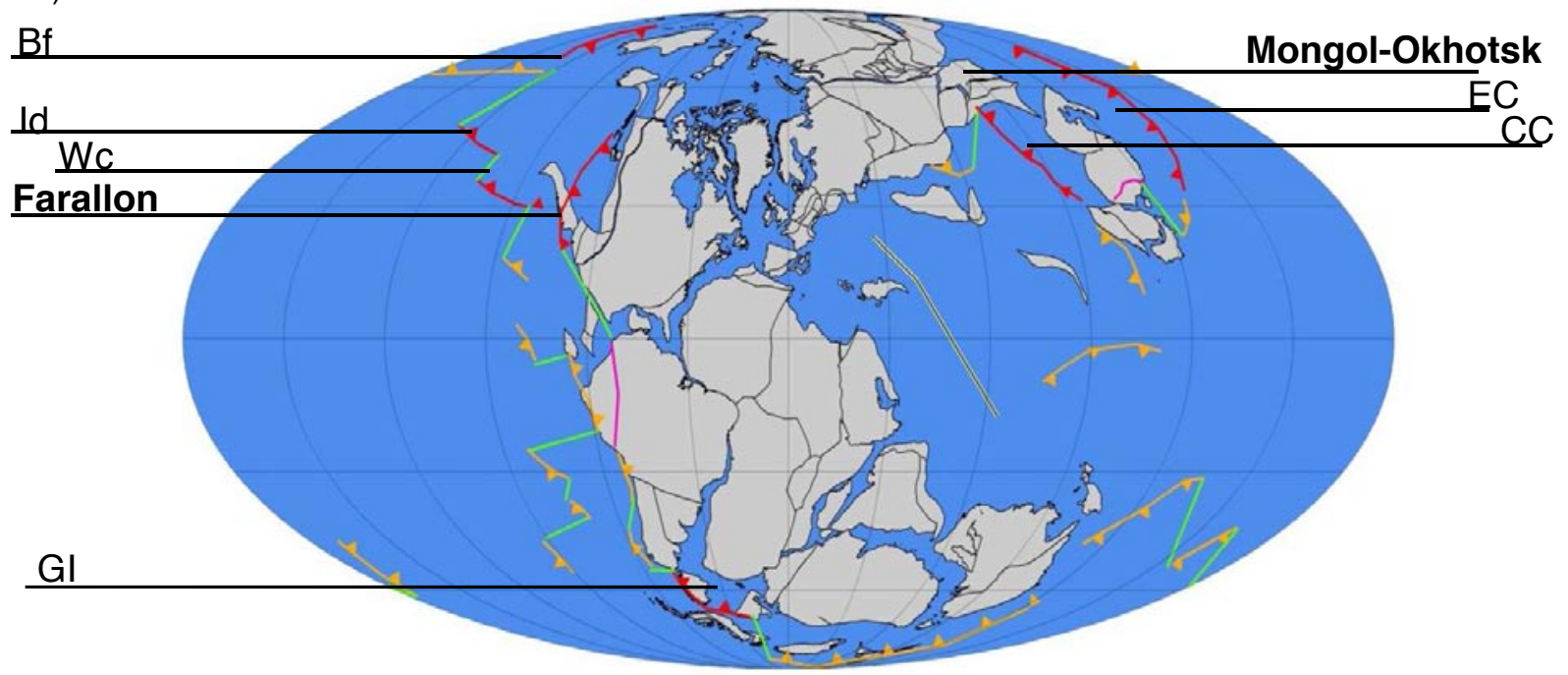

ـ Subduction 1st-3rd category Spreading Ridge

A. Other subduction Zones_-Transfer zones

_ Flat Slab Subduction

Supplementary Figure 37 a) Tomographic slice at $2300 \mathrm{~km}$ depth of Amaru (2007) projected to the earth's surface, b) modified reconstruction of Torsvik et al. (2008) at 200 Ma with the interpreted subduction zones and other tectonic features. The top of the Mongol-Okhotsk slab is found at this depth. This is the northern part of the Z-shaped anomaly of van der Voo (1999a) and was estimated to be approximately 150 Ma old. According to Stampfli and Borel (2004) subduction ceased between North China and Siberia between 180 and $155 \mathrm{Ma}$. Interpretations of other slabs yields 175-225 Ma. A global 15 degree westward shift was applied to the 200 Ma plate tectonic reconstruction (Torsvik et al. (2008)) to obtain a best-fit for this depth. 
a)

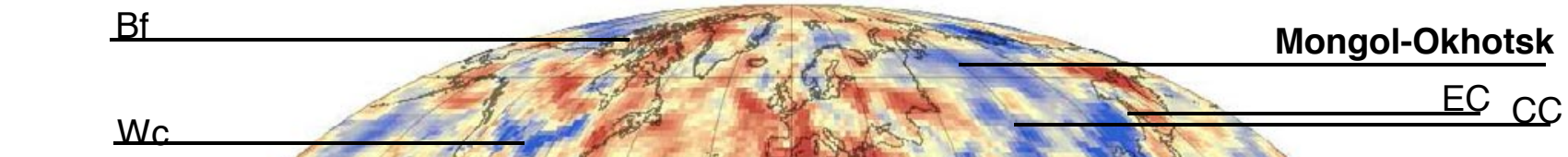

Farallon

TA

GI
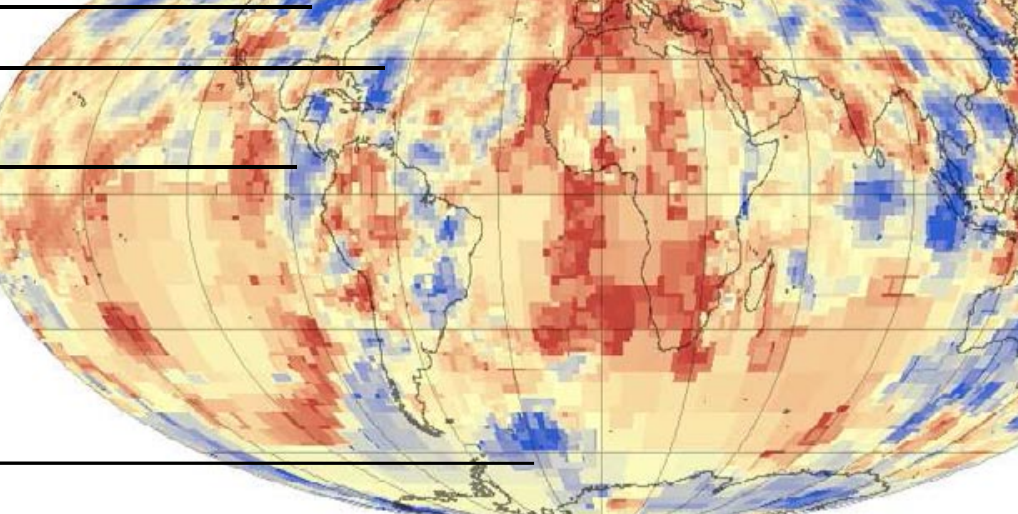
Legend
P-wave velocity anomaly
$-0.4 \%+0.4 \%$

b)

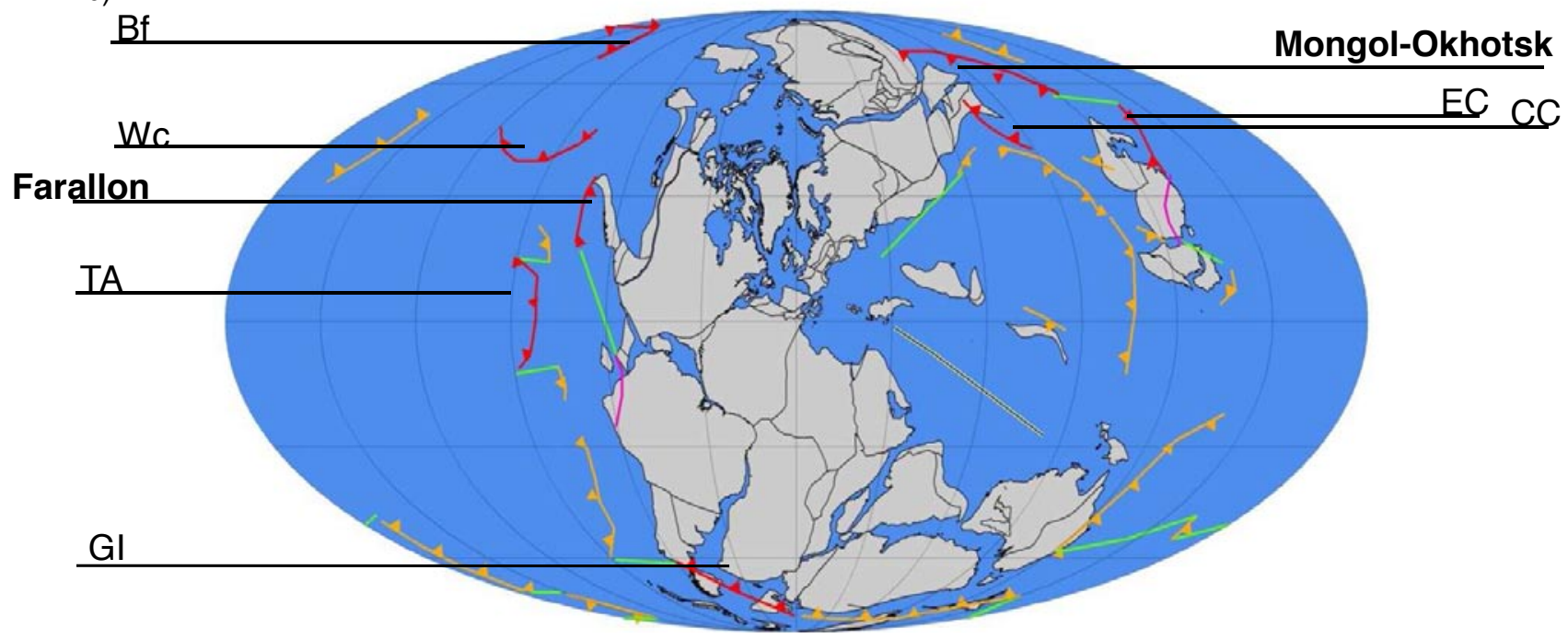

^ Subduction 1st-3rd category Spreading Ridge

_. Other subduction Zones_-Transfer zones

_ Flat Slab Subduction

Supplementary Figure 38 a) Tomographic slice at $2480 \mathrm{~km}$ depth of Amaru (2007) projected to the earth's surface, b) modified reconstruction of Torsvik et al. (2008) at 220 Ma with the interpreted subduction zones and other tectonic features. The base of the Farallon slab is found at this depth and base was initially estimated to be approximately 100 Ma old (Grand et al. (1997)). However several orogenic phases (Nevadan, Sevier, Laramide), occurred at the western Laurentian margin, suggesting continuous convergence in this region since the Jurassic. We assume subduction to have initiated between 207-180 Ma (Ward (1995)), or 193-163 Ma (Nokleberg et al. (2000)) causing the base of the Farallon slab. This new interpretation is in agreement with the Aegean Tethys and Mongol-Okhotsk anchor points. Interpretations of other slabs yields $185-235 \mathrm{Ma}$. A global 12 degree westward shift was applied to the 200 Ma plate tectonic reconstruction (Torsvik et al. (2008)) to obtain a best-fit for this depth. 
a)

\section{$2650 \mathrm{~km}-240 \mathrm{Ma}$}

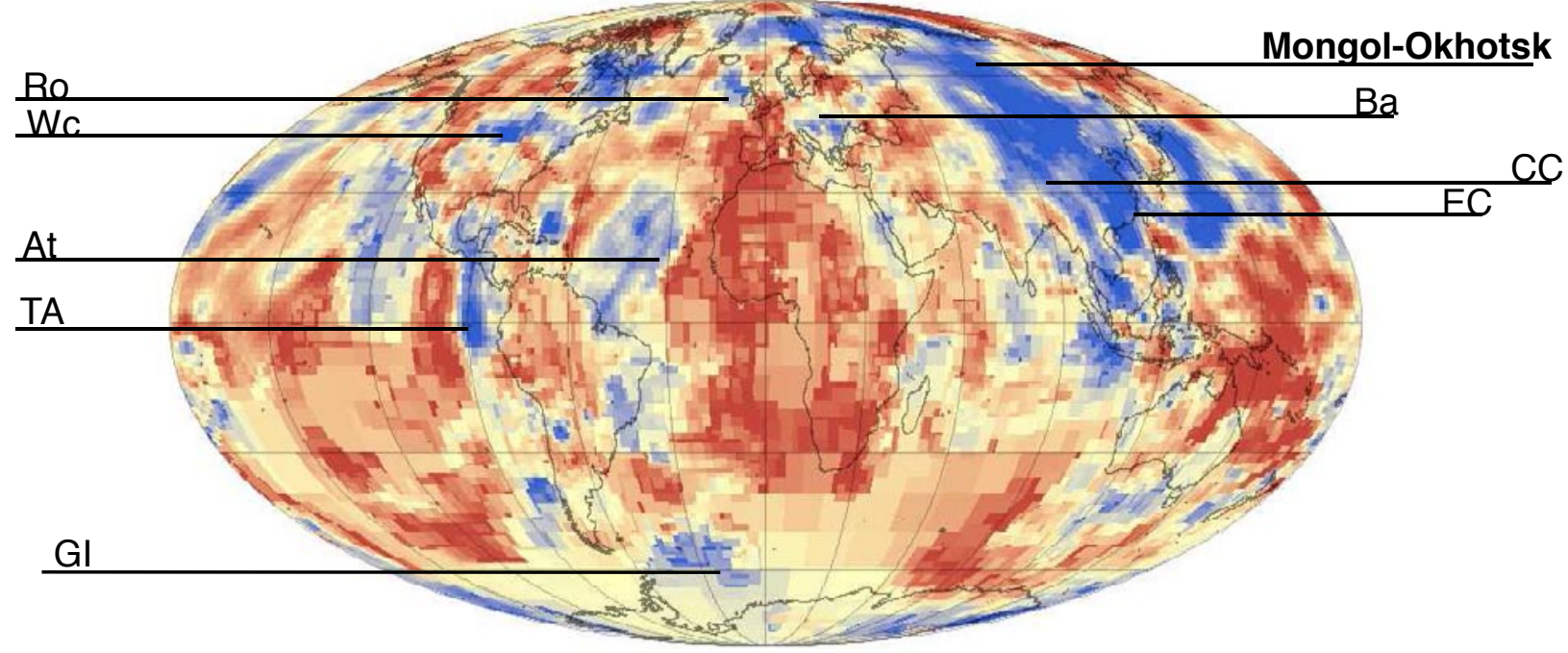

Legend

P-wave velocity anomaly

$-0.4 \%+0.4 \%$

b)

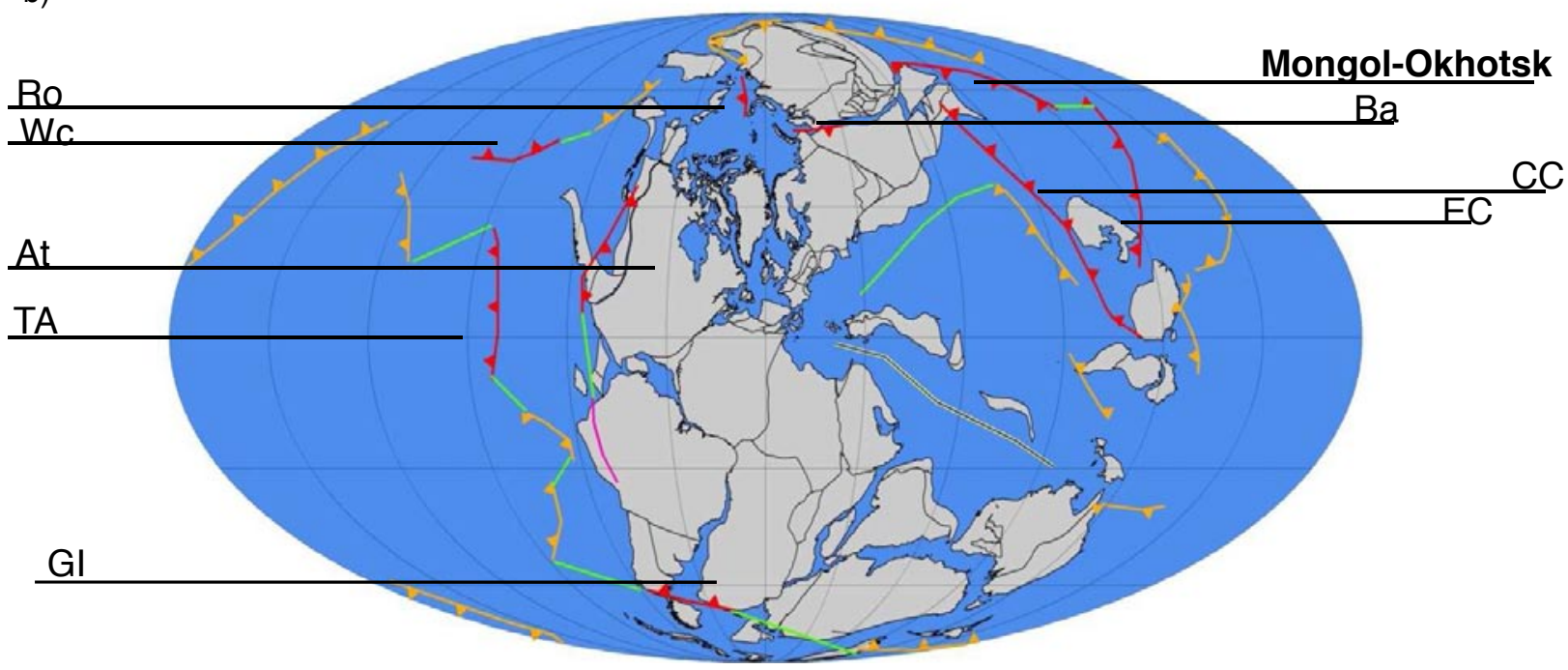

- Subduction 1st-3rd category Spreading Ridge

_. Other subduction Zones_-Transfer zones

_ Flat Slab Subduction

Supplementary Figure 39 a) Tomographic slice at $2650 \mathrm{~km}$ depth of Amaru (2007) projected to the earth's surface, b) modified reconstruction of Torsvik et al. (2008) at $240 \mathrm{Ma}$ with the interpreted subduction zones and other tectonic features. Based on the base Farallon and top Mongol-Okhotsk anchor points above and the base Mongol-Okhotsk anchor point below, an age of $\sim 210 \mathrm{Ma}$ is expected for this depth. Interpretations of other slabs yields $210-245 \mathrm{Ma}$. A global 10 degree westward shift was applied to the 240 Ma plate tectonic reconstruction (Torsvik et al. (2008)) to obtain a best-fit for this depth. 
a)

\title{
2815 km - $260 \mathrm{Ma}$
}

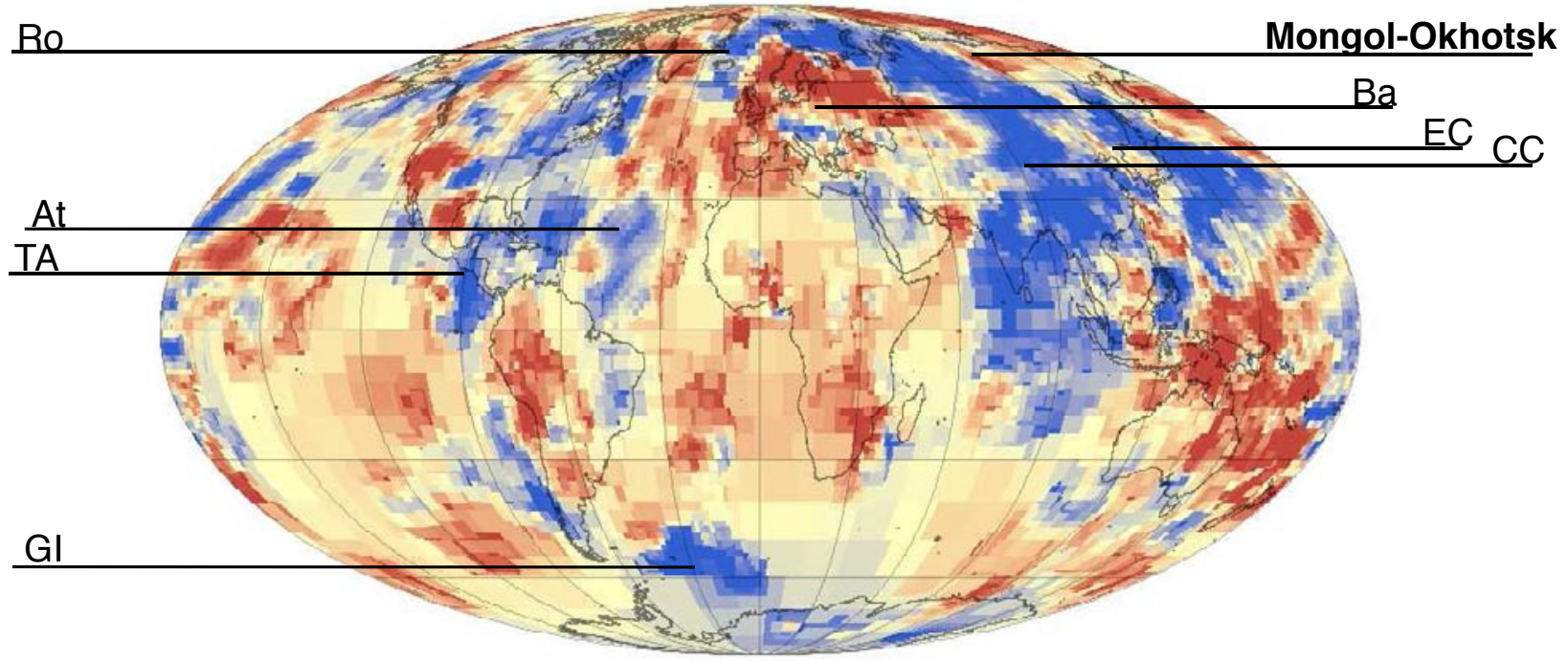

\begin{abstract}
Legend
$\mathrm{P}$-wave velocity anomaly

$-0.4 \%+0.4 \%$
\end{abstract}

b)

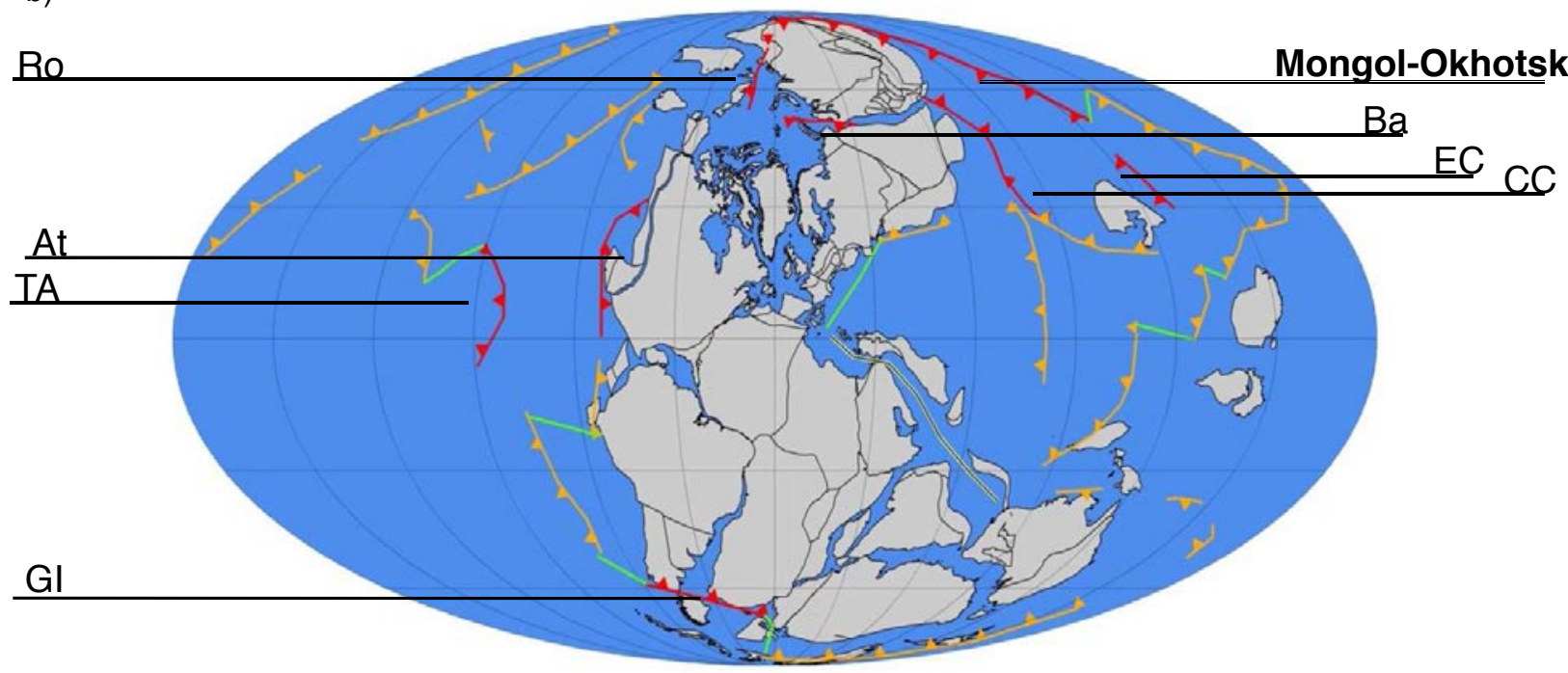

^ Subduction 1st-3rd category Spreading Ridge

$\_$Other subduction Zones__ _ Transfer zones

_ Flat Slab Subduction

Supplementary Figure 40 a) Tomographic slice at 2815 km depth of Amaru (2007) projected to the earth's surface, b) modified reconstruction of Torsvik et al. (2008) at 260 Ma with the interpreted subduction zones and other tectonic features. The base of the Mongol-Okhotsk slab is found at this depth. This is the northern part of the Z-shaped anomaly (van der Voo et al. (1999a)) and was estimated to be at least 200 Ma old. We have adopted a start of subduction between North China and Siberia between 240 and $230 \mathrm{Ma}$ (Stamplfi and Borel (2004)). Interpretations of other slabs yields 230-270 Ma. A global 8 degree westward shift was applied to the 260 Ma plate tectonic reconstruction (Torsvik et al. (2008)) to obtain a best-fit for this depth. 


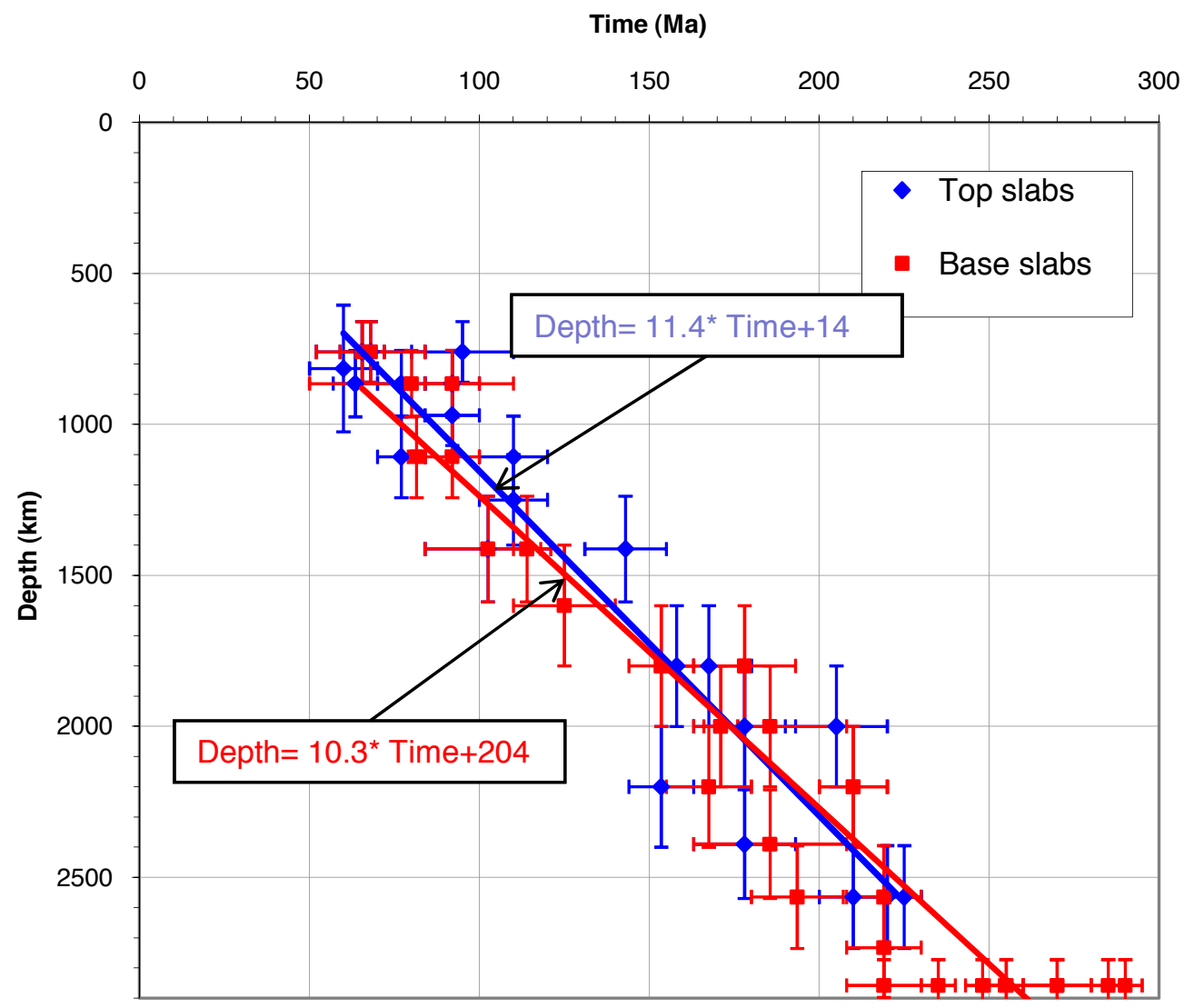

Supplementary Figure 41 Time-depth graphs with trendlines of a) all lower mantle slabs with error margins and b) split in tops and bases. 


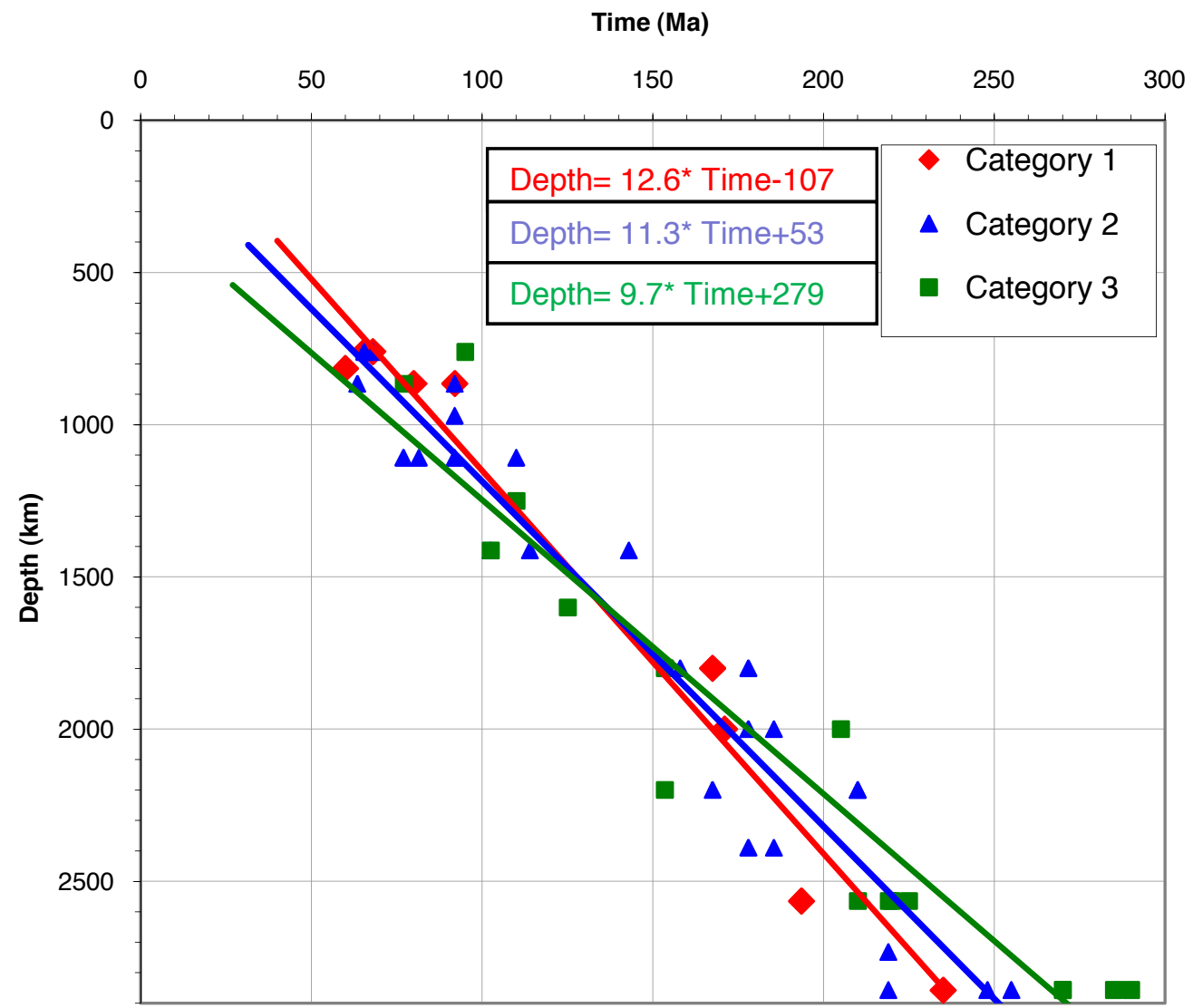

Supplementary Figure 42 Time-depth graphs of the lower mantle slab datapoints and trendlines split per a) category b) tectonic domain. 


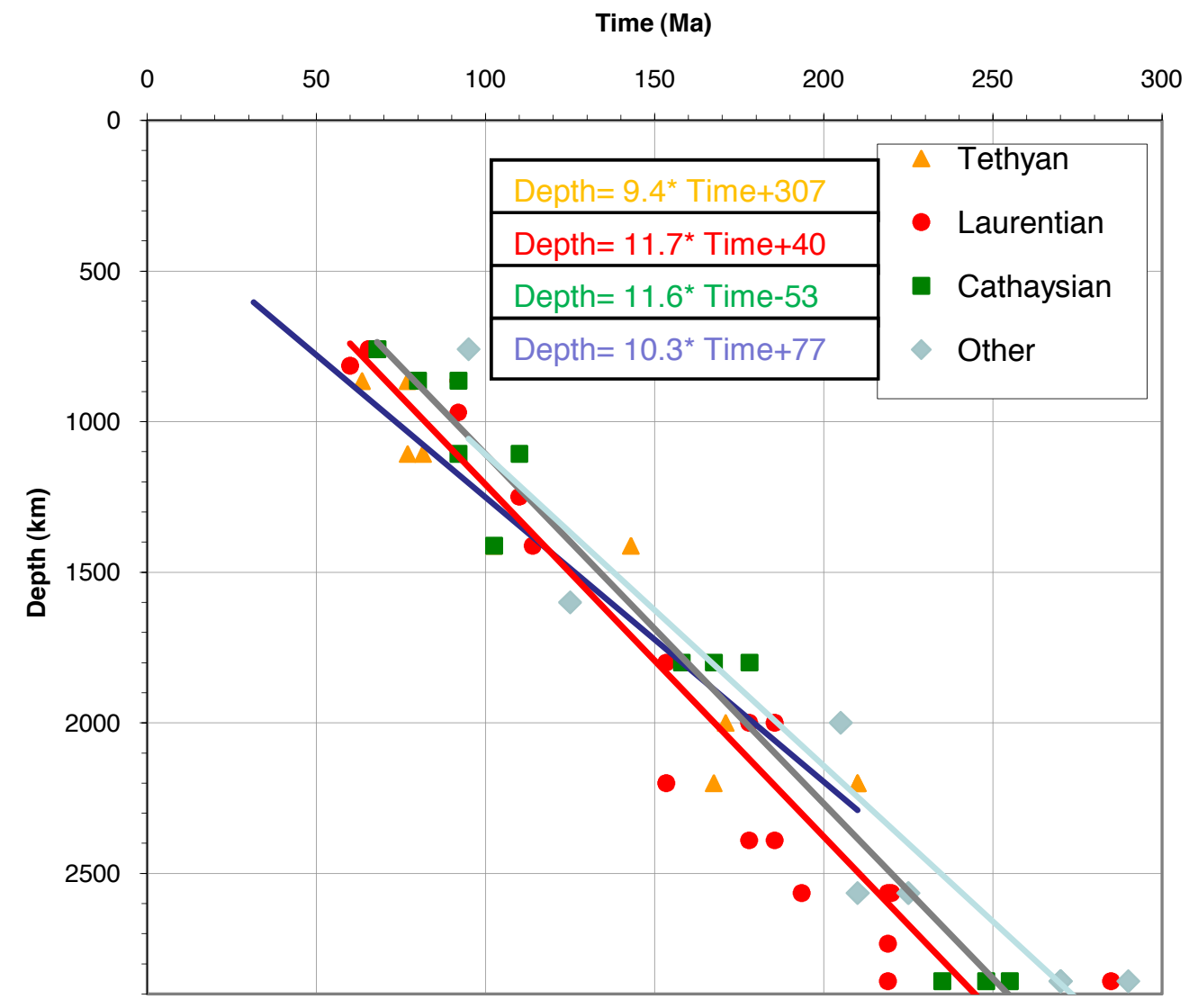

Supplementary Figure 43 Time-depth graphs of the lower mantle slab datapoints and trendlines split per a) category b) tectonic domain. 


\section{References Supplementary Information:}

Abdelwahed, M.F., and Zhao, D., 2007, Deep structure of the Japan subduction zone, Physics of The Earth and Planetary Interiors, v. 162, p. 3252.

Alexeiev, D.V., Gaedicke, C., Tsukanov, N.V., and Freitag, F., 2006, Collision of the Kronotskyi arc at the NE Eurasia margin and structural evolution of the Kamchatka-Aleutian junction, International Journal of Earth Sciences, p. 977-993.

Amaru, M.L., 2007, Global travel time tomography with 3-D reference models, Geologica Ultraiectina, v. 274.

Barboza-Gudiño, J.R., Orozco-Esquivel, M.T., Gómez-Anguiano, M., and Zavala-Monsiváis, A., 2008, The Early Mesozoic volcanic arc of western North America in northeastern Mexico, Journal of South American Earth Sciences, v. 25, p. 49-63.

Brueckner, H.K., Avé Lallemant, H.G., Sisson, V.B., Harlow, G.E., Hemming, S.R., Martens, U., Tsujimori, T. and Sörensen, S.S., 2009, Metamorphic reworking of a high pressure-low temperature mélange along the Motagua fault, Guatemala: A record of Neocomian and Maastrichtian transpressional tectonics, Earth and Planetary Science Letters, v. 284, p. 228-235.

Burke, K., 1988, Tectonic evolution of the Caribbean, Annual Review of Earth and Planetary Sciences, v. 16, p. 201-230.

Cawood, P.A. and Buchan, C., 2007, Linking accretionary orogenesis with supercontinent assembly, Earth Science Reviews, v. 82, p. 217-256.

Cocks, R.L., and Torsvik, T.H., 2007, Siberia, the wandering northern terrane, and its changing geography through the Paleozoic, Earth Science Reviews, v. 82, p. 29-74.

DeCelles, P.G., Ducea, M.N.D., Kapp, P. and Zandt, G., 2009, Cyclicity in Cordilleran orogenic systems, Nature Geoscience, v. 2, p.251-257

Dickinson, W., and Snyder, W., 1978, Plate tectonics of the Laramide orogeny, Geological Society of America Memoirs, v. 151, p. $355-366$.

Engebretson, D.C., Cox, A., and Gordon, R.G., 1985, Relative motions between oceanic and continental plates in the Pacific Basin, Geological Society of America Special Paper, $59 \mathrm{p}$.

Fukao, Y. Widiyantoro, S. and Obayashi, M., 2001, Stagnant slabs in the upper and lower mantle transition region, Reviews of Geophysics, v.39 (3), p.291-323

García-Casco, A., Iturralde-Vinent, M.A., and Pindell, J., 2008a, Latest Cretaceous collision/accretion between the Caribbean Plate and Caribeana: Origin of metamorphic terranes in the Greater Antilles, International Geology Review, v. 50, p. 781-809.

García-Casco, A., Lázaro, C., Rojas-Agramonte, Y., Kröner, A., Torres-Roldán, R.L., Núñez, K., Neubauer, F., Millán, G., and Blanco-Quintero, I., 2008b, Partial melting and counterclockwise P-T path of subducted oceanic crust (Sierra del Convento Mélange, Cuba), Journal of Petrology, v. 49, p. 129-161.

García-Casco, A., Torres-Roldan, R., Millan, G., Monié, P., and Schneider, J., 2002, Oscillatory zoning in eclogite garnet and amphibolite, Northern Serpentinite Melange, Cuba: a record of tectonic instability during subduction?, Journal of Metamorphic Geology, v. 20, p. 581-598.

Gorbatov, A., Widiyantoro, S., Fukao, Y., and Gordeev, E., 2000, Signature of remnant slabs in the North Pacific from P-wave tomography, Geophysical Journal International, v. 142, p. 27-36.

Golonka, J., Bocharova, N.Y., Ford, D., Edrich, M.E., Bednarczyk, J. and Wildharber, J., 2003, Paleogeographic reconstructions and basins development of the Arctic, Marine and Petroleum Geology, v. 20, p. 211-248.

Grand, S., van der Hilst, R.D., and Widiyantoro, S., 1997, Global seismic tomography: a snapshot of convection in the earth, GSA Today, v. 7, p. $1-7$.

Hafkenscheid, E., Wortel, M.J.R., and Spakman, W., 2006, Subduction history of the Tethyan region derived from seismic tomography and tectonic reconstructions, Journal of Geophysical Research, v. 111, p. B08401, doi: 10.1029/2005JB003791.

Harlow, G.E., Hemming, S.R., Avé Lallemant, H.G., Sisson, V.B., and Sorensen, S.S., 2004, Two high-pressure - low-temperature serpentinitematrix mélange belts, Motagua fault zone, Guatemala: A record of Aptian and Maastrichtian collisions, Geology, v. 32, p. 17-20.

Hutko, A.R., Lay, T., Garnero, E.J., and Revenaugh, J., 2006, Seismic detection of folded subducted lithosphere at the core-mantle boundary, Nature, v. 441, p. 333-336.

Jiang, G., Zhao. D. and Zhang, G., 2009, Seismic tomography of the Pacific slab edge under Kamchatka, Tectonophysics, v. 465, p. 190-203

Johnston, S.T. and Borel, G.D., 2007, The odyssey of the Cache Creek terrane, Canadian Cordillera: Implications for accretionary orogens, tectonic setting of Panthalassa, the Pacific superwell, and break-up of Pangea, Earth and Planetary Science Letters, v. 253, p. 415-428

Keppie, J.D., Nance, R.D., Dostal, J., Ortega-Rivera, A., Miller, B.V., Fox, D., Muise, J., Powell, J.T., Mumma, S.A. and Lee, J.W.K.,(2004, MidJurassic tectonothermal event superposed on a Paleozoic geological record in the Acatlán Complex of southern Mexico: Hotspot activity during the breakup of Pangea, Gondwana Research, v.7, No1, p.239-260

Kito, T., Rost, S., Thomas, C., Garnero, E.J.,, 2007, New insights into the P-and S-wave velocity structure of the D" discontinuity beneath the Cocos plate, Geophysical Journal International, v. 169, p. 631-645.

Krebs, M., Maresch, W.V., Schertl, H.-P., Münker, C., Baumann, A., Draper, G., Idleman, B., and Trapp, E., 2008, The dynamics of intra-oceanic subduction zones: A direct comparison between fossil petrological evidence (Río San Juán Complex, Dominican Republic) and numerical simulation, Lithos, v.103, no. 1-2, p. 106-137

Lázaro, C., García-Casco, A., Rojas Agramonte, Y., Kröner, A., Neubauer, F. \& Iturralde-Vinent, M.A., 2009, Fifty-five-million-year history of oceanic subduction and exhumation at the northern edge of the Caribbean plate (Sierra del Convento mélange, Cuba), Journal of Metamorphic Geology, v. 27, p. 19-40.

Liati, A., Gebauer, D., and Fannink, C.M., 2004, The age of ophiolitic rocks of the Hellenides (Vourinos, Pindos, Crete): first U-Pb ion microprobe (SHRIMP) zircon ages, Chemical Geology, v. 207, p. 171-188.

$\mathrm{Li}, \mathrm{Z}$.-X. and Li, X.-H., 2007, Formation of the 1300-km-wide intracontinental orogen and postorogenic magmatic province in Mesozoic South China: A flat-slab subduction model, Geology, v.35, no.2, p.179-182

Liu, L, Spasojevic, S. and Gurnis, M., Reconstruction of the Farallon plate subduction beneath North America back to the Late Cretaceous, Science, v. 232, p. 934-938.

Miller, M.S., and Kennett, B.L.N., 2006, Evolution of mantle structure beneath the northwest Pacific: Evidence from seismic tomography and paleogeographic reconstructions, Tectonics, v. 25, p. 1-14.

Martin, A.K., 2007, Gondwana breakup via double-saloon-door rifting and seafloor spreading in a backarc basin during subduction rollback, Tectonophysics, v. 445, p. 245-272.

Leier, A.L., DeCelles, P.G., Kapp, P. and Ding, L., 2007, The Takena formation of the Lhasa terrane, southern Tibet: The record of a Late Cretaceous retroarc foreland basin, GSA Bulletin, v. 119 (1-2), p. 31-48.

Natal'in, B.A. and Sengör, A.M.C., (2005), Late Palaeozoic to Triassic evolution of the Turan and Scythian platforms: The pre-history of the Palaeo-Tethyan closure, Tectonophysics, v. 404, p. 175-202. 
Nokleberg, W.J., Parfenov, L.M., Monger, J.W.H., Norton, I.O., Khanchuk, A.I., Stone, D.B., Scotese, C.R., Scholl, D.W. and Fujita, K., 2000, Phanerozoic tectonic evolution of the circum-north Pacific, USGS Professional Paper 1626.

Okay, A.I., Satir, M., Tüysüz, O., Akyüz, S. and Chen F., 2001 The tectonics of the Strandja Massif: late-Variscan and mid-Mesozoic deformation and metamorphism in the northern Aegean, International Journal Earth Science, v. 90, p. 217-233.

Qi, C., Zhao, D., and Chen, Y., 2007, Search for deep slab segments under Alaska, Physics of The Earth and Planetary Interiors, v. 165, p. 6882.

Ramos, V.A., 2008, Patagonia: A paleozoic continent adrift?, Journal of South American Earth Sciences, v. 26 (3), p. $235-251$.

Ren, Y., Stutzmann, E., van der Hilst, R.D., and Besse, J., 2007, Understanding seismic heterogeneities in the lower mantle beneath the Americas from seismic tomography and plate tectonic history, Journal of Geophysical Research, v. 112, p. B01302, doi:10.1029/2005JB004154.

Roger, F., Jolivet, M. and Malaveille, J., 2008, Tectonic evolution of Triassic fold belts of Tibet, Comptes Rendus Geoscience, v. 340, p. 180-189.

Ross, M.I., Scotese, C.R.,, 1988, A hierarchical tectonic model of the Gulf of Mexico and Caribbean region, Tectonophysics, v. 155, p. $139-168$.

Sagong, H., Kwon, S.-T., Ree, J.-H., 2005, Mesozoic episodic magmatism in South Korea and its tectonic implication. Tectonics, v. 24, p. TC5002, doi:10.1029/2004TC001720

Sigloch, K., McQuarrie, N., and Nolet, G., 2008, Two-stage subduction history under North America inferred from multiple-frequency tomography, Nature Geoscience, v. 1, p. 458-462.

Simancas, J.F., Tahiri, A., Azor, A., Lodeiro, F.G., Martínez Poyatos, D.J., and El Hadi, H., 2005, The tectonic frame of the Variscan-Alleghanian orogen in Southern Europe and Northern Africa, Tectonophysics, v. 398, p. 181-198.

Stampfli, G.M., and Borel, G.D., 2004, The TRANSMED transects in space and time: Constraints on the paleotectonic evolution of the Mediterranean domain, in Cavazza, W., Roure, F., Spakman, W., Stampfli, G.M., and Ziegler, P., eds., The TRANSMED Atlas: the Mediterranean Region from Crust to Mantle: Berlin, Springer Verlag, p. 53-76.

Thomas, C., Garnero, E.J., Lay, T., 2004, High-resolution imaging of lowermost mantle structure under the Cocos plate, J. Geophys. Res., v. 109 p. B08307, doi:10.1029/2004JB003013.

Torsvik T., Müller, D.M, van der Voo, R., Steinberger, B. And Gaina, C., 2008, Global plate motion frames: toward a unified model. Reviews of Geophysics, v. 46, p. 1-44. Corrected for True Polar Wander between 100-300 Myr after Steinberger, B. And Torsvik, T.H., 2008, Absolute plate motions and true polar wander in the absence of hotspot tracks. Nature, v. 452 ,

Trop, J.M., Szuch, D.A, Rioux, M., and Blodgett, R.B., 2005, Sedimentology and provenance of the Upper Jurassic Naknek Formation, Talkeetna Mountains, Alaska; bearings on the accretionary tectonic history of the Wrangellia composite terrane, Geological Society of America Bulletin, v. 117(5-6), p. 570-588.

van der Hilst, R.D., de Hoop, M.V., Wang, P., Shim, S.-H., Ma, P., and Tenorio, L., 2007, Seismostratigraphy and Thermal Structure of Earth's Core-Mantle Boundary Region, Science, v. 315, p. 1813-1817.

van der Hilst, R.D., Engdahl, E.R., Spakman, W., and Nolet, G., 1991, Tomographic imaging of subducted lithosphere below northwest Pacific island arcs, Nature, v. 353, p. 37-42.

van der Hilst, R.D. and Spakman, W., 1989, Importance of reference model in linearized tomography and images of subduction below the Caribbean plate, Geophysical Research Letters, v. 16 (10), p. 1093-1096

van der Lee, S., and Nolet, G., 1997, Seismic image of the subducted trailing fragments of the Farallon plate, Nature v. 386, p. 266-269.

van der Voo, R., Spakman, W., and Bijwaard, H., 1999a, Mesozoic subducted slabs under Siberia, Nature, v. 397, p. $246-249$.

-, 1999b, Tethyan slabs under India, Earth and Planetary Science Letters, v. 171, p. 7-20. p. 620-623.

van Hinsbergen, D.J.J., Hafkenscheid, E., Spakman, W., Meulenkamp, J.E., and Wortel, M.J.R., 2005, Nappe stacking resulting from subduction of oceanic and continental lithosphere below Greece, Geology, v. 33, p. 325-328.

Ward, P.L., 1995, Subduction cycles under western North America during the Mesozoic and Cenozoic eras, GSA Special Paper, v. 299, p. 1-40.

Warren, C.J., Parrish, R.R., Searle, M.P. and Waters, D.J., 2003, Dating the subduction of the Arabian continental margin beneath the Semail ophiolite, Oman, Geology, v. 31 (10), p. 889-892.

Ziegler, P.A., 1989, Evolution of Laurussia, Dordrecht, Kluwer Academic Publications, 102 p. 